STATE DOEUMENTS EOLLECTION

\title{
HIM 201992
}

MONTANA STATE LIBRARY

1515 E. 6th AVE

HELENA, MONTANA 59620

\section{Statewide Water Pollution Studies \\ Jriennial Report 1984-86}

Glenn R. Phillips

Kurt Hill

and

Ann B. Humphrey

October, 1987

Pollution Control Information Series No. 6 
iate jine

APR -51999

MAY 6 - iอง

JUN $1 \varepsilon \cdot 3$

MAY 62002

HAY 232003 


\section{Statewide Water Pollution Studies \\ Triennial Report \\ 1984-86}

by

Glenn R. Phillips

Kurt Hill

and

Ann B. Humphrey

\section{Pollution Control Information Series}

Technical Report No. 6

\section{Montana Department of Fish, Wildlife and Parks \\ 1420 East Sixth Avenue \\ Helena, Montana 59620}


-

0

. 


\section{CONTENTS}

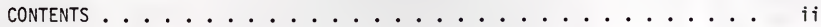

ACKNOWLEDGEMENT $\ldots \ldots \ldots \ldots \ldots \ldots \ldots \ldots \ldots \ldots$

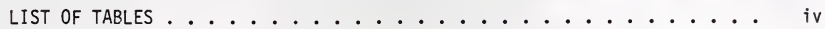

LIST OF FIGURES ................................ vii

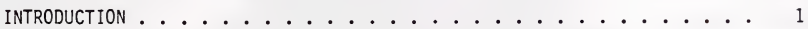

TOXICITY OF STREAM WATER IN THE CLARK FORK AND BOULDER RIVER

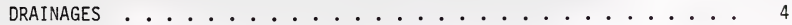

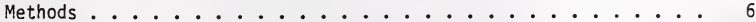

Results ....................... 10

STREAMFLOW AND DIURNAL DISSOLVED OXYGEN TRENDS IN UPPER MISSOURI

RIVER DRAINAGE STREAMS .............................. 48

Methods . . . . . . . . . . . . . . . . 48

Results ......................... 49

SEASONAL AND DIURNAL CHANGES IN THE WATER CHEMISTRY OF HAMBY

LAKE, BEAVERHEAD MOUNTAINS .................. 58

Methods . . . . . . . . . . . . . . . 59

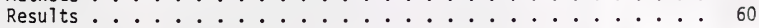

BASEL INE WATER CHEMISTRY OF ALPINE LAKES IN THE SPANISH PEAKS

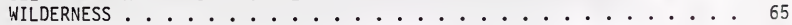

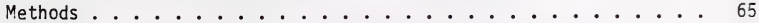

Results....................... 66

INVENTORY OF FISHERY HABITAT IN THE UPPER CLARK FORK RIVER . . . . 69

Methods . . . . . . . . . . . . . . 69

Results . . . . . . . . . . . . . . 72

CHLORINATED HYDROCARBONS IN MONTANA FISHES . . . . . . . 76

Methods . . . . . . . . . . . . . . . 76

Results . . . . . . . . . . . . . 77

SUPERSATURATION OF DISSOLVED GASES IN THE MISSOURI RIVER

DOWNSTREAM OF HAUSER DAM . . . . . . . . . . . . . . . . 84

Methods . . . . . . . . . . . . . . . . 84

Results ...................... 85

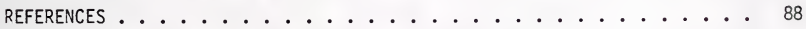


-

0

- 
We would like to express our sincere appreciation to all of the individuals and agencies that helped us complete our work. Jim Crepeau of the Jocko River Hatchery provided fish for the bioassays; the Wisdom Ranger District, Beaverhead National Forest, provided labor for helping transport gear into Hamby Lake; Jim Lloyd, Gallatin National Forest, collected water samples from lakes in the Spanish Peaks Wilderness; Gwynn Stanhope provided valuable assistance in completing the Clark Fork River habitat inventory and the Hamby Lake work; Bill Gardner, Lanny Hanzel, Wade Fredenberg, Steve McMullin, Jim Peterson, and Rod Berg helped collect fish for residue testing; Jack Smith of Montana Power Company adjusted water release patterns from Hauser Dam so that we could test the effects of release pattern on supersaturation of dissolved gases.

This work was completed in the interest of the sportsmen of Montana. 
-

○

? 
Table 1. Alkalinity, hardness and $\mathrm{pH}$ at several locations in the Boulder River drainage .............

Table 2. Zinc loading at the mouths of Basin, Cataract, and High

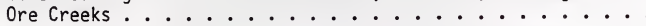

Table 3. Copper loading at the mouths of Basin, Cataract, and High Ore Creeks

Table 4. Zinc loading at several locations in Basin Creek and

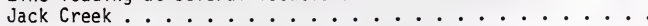

Table 5. Results of instream bioassays using fingerling rainbow trout in High Ore Creek near its mouth .........

Table 6. Results of instream bioassays using fingerling rainbow trout in Cataract Creek near its mouth .........

Table 7. Results of instream bioassays using fingerling rainbow trout in Bas in Creek near its mouth ..........

Table 8. Results of instream bioassays using fingerling rainbow trout in the Boulder River upstream of the town of Basin

Table 9. Results of instream bioassays using fingerling rainbow trout in the Boulder River upstream of High Ore Creek

Table 10. Results of instream bioassays using fingerling rainbow trout in the Boulder River downstream of High Ore Creek

Table 11. Results of instream bioassays using fingerling rainbow trout in the Boulder River upstream of High Ore Creek ....

Table 12. Results of instream bioassays using fingerling rainbow trout in the Boulder River downstream of High Ore

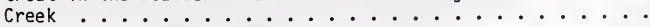

Table 13. Alkalinity, hardness and pH at five locations in the Clark Fork River and in Silver Bow and Racetrack Creeks

Table 14. Zinc loading at five locations in the Clark Fork River

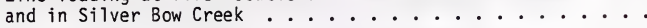

Table 15. Copper loading at five locations in the Clark Fork River and in Silver Bow Creek 
.

0

- 
Table 16. Results of instream bioassay using fingerling rainbow

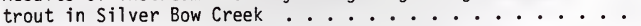

Table 17. Results of instream bioassay using fingerling rainbow trout in Racetrack Creek near Racetrack ......... 41

Table 18. Results of instream bioassay using fingerling rainbow trout in the Clark Fork River near Warm Springs ..... 42

Table 19. Results of instream bioassay using fingerling rainbow trout in the Clark Fork River near Deer Lodge .......

Table 20. Results of instream bioassay using fingerling rainbow trout in the Clark Fork River near Gold Creek ......

Table 21. Results of instream bioassay using fingerling rainbow trout in the Clark Fork River near Bearmouth .......

Table 22. Results of instream bioassay using fingerling rainbow trout in the Clark Fork River near Clinton ........

Table 23. Relative sensitivity to acid deposition of 63 alpine lakes from several Montana mountain ranges. Rating scheme developed by EPA and based on total alkalinity of surface waters

Table 24. Specific conductance, $\mathrm{pH}$ and concentrations of major cations and anions in surface waters from ten alpine lakes in the Spanish Peaks Wilderness .........

Table 25. Specific conductance, $\mathrm{pH}$ and concentrations of major cations and anions in surface waters from ten alpine lakes in the Spanish Peaks Wilderness .........

Table 26. Habitat features of the Clark Fork River for 1000-2000 foot stream segments between Warm Springs and $\mathrm{Cl}$ inton;

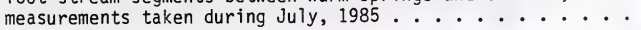

Table 27. Concentrations of chlorinated hydrocarbons in muscle tissue from brown trout collected from the Bighorn River near Fort Smith; June and July, 1984

Table 28. Concentrations of chlorinated hydrocarbons in muscle tissue from mountain whitefish collected from the Clark Fork River near Plains during October 1985 ........

Table 29. Concentrations of chlorinated hydrocarbons in muscle tissue from brown trout, rainbow trout, and mountain whitefish collected from the Missouri River near Carter Ferry during lune $1986 \ldots \ldots \ldots \ldots$ 
Table 30. Concentrations of chlorinated hydrocarbons in muscle tissue from kokanee salmon collected from Flathead Lake at Skidoo Bay; May 12, 1984

Table 31. Concentrations of chlorinated hydrocarbons in muscle tissue from lake trout and bull trout collected from the west side of Flathead Lake during February or April of 1985

Table 32. Dissolved Oxygen concentration, water temperature, and percent saturation of total dissolved gases in the Missouri River downstream of Hauser Dam under various dam spillage patterns in May, 1985 
.

-

- 
Figure 1. Map of the Upper Boulder River; diamonds indicate bioassay sites............... 7

Figure 2. Map of the Upper Clark Fork River drainage; diamonds indicate bioassay locations ............ 9

Figure 3. Total recoverable zinc concentrations at bioassay sites in the Boulder River drainage ........ 12

Figure 4. Total recoverable copper concentrations at bioassay sites in the Boulder River drainage ......... 14

Figure 5. Cumulative percent mortality of fingerling rainbow trout kept in Basin, High Ore, and Cataract Creeks . . . . 19

Figure 6. Cumulative percent mortality of fingerling rainbow trout kept in Basin, High Ore, and Cataract Creeks . . . . . 24

Figure 7. Cumulative percent mortality of rainbow trout kept in the Boulder River above and below High Ore Creek . . . . 25

Figure 8. Total recoverable zinc concentrations at bioassay sites in the Clark Fork River drainage ........ 33

Figure 9. Stream discharge at several locations in the Clark

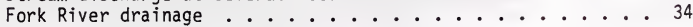

Figure 10. Total recoverable copper concentrations at bioassay sites in the Clark Fork River drainage ........ 35

Figure 11. Cumulative percent mortality of fingerling rainbow trout kept at several locations in the Clark Fork

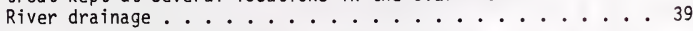

Figure 12. Diurnal changes in dissolved oxygen concentration and percentage saturation of dissolved oxygen at differing streamflows in the Ruby River ......... 50

Figure 13. Diurnal changes in dissolved oxygen concentration and percentage saturation of dissolved oxygen at differing streamflows in the Beaverhead River ...... 51

Figure 14. Diurnal changes in dissolved oxygen concentration and percentage saturation of dissolved oxygen at differing streamflows in the Big Hole River ....... 52

Figure 15. Diurnal changes in dissolved oxygen concentration and percentage saturation of dissolved oxygen at differing streamflows in the Jefferson River ....... 5 
-

○

- 
Figure 16. Diurnal changes in dissolved oxygen concentration and percentage saturation of dissolved oxygen at differing streamflows in the East. Gallatin River. . . . . . 54

Figure 17. Diurnal changes in dissolved oxygen concentration and percentage saturation of dissolved oxygen at differing streamflows in the West Gallatin River...... 55

Figure 18. Diurnal changes in dissolved oxygen concentration and percentage saturation of dissolved oxygen at differing streamflows in Little Prickly Pear Creek . . . . . 56

Figure 19. Diurnal trends at several depths in Hamby Lake for total alkalinity, $\mathrm{pH}$, dissolved oxygen concentration, and water temperature (July $1-2,1986) \ldots \ldots 1$

Figure 20. Diurnal trends at several depths in Hamby Lake for total alkalinity, $\mathrm{pH}$, dissolved oxygen concentration, and water temperature (August $14-15,1985) \ldots \ldots$. . . . 62

Figure 21. Diurnal trends at several depths in Hamby Lake for total alkalinity, $\mathrm{pH}$, dissolved oxygen concentration, and water temperature (September 19-20, 1984) ...... 63

Figure 22. Map of the Clark Fork River; arrows indicate reaches where stream habitat was inventoried ......... 70 
-

-

- 
INTRODUCTION

Each year personnel from the Pollution Control Program of the Department of Fish, Wildlife and Parks collect information to help us understand factors that may limit fish and wildlife resources. Often times the information that is collected on a given project is not comprehensive enough to warrant a report of its own. Nevertheless we feel that it is worthwhile to summarize the information; hence in recent years we have begun publishing the results of smaller projects in a biennial or triennial report.

Because of the variety of topics and objectives for collecting information, each sub-project is covered in a separate section of the report. This format will help readers find the particular topic that they are interested in without having to read the entire report.

Sub-projects that were completed and the objectives for collecting the information were as follows:

(1) Assessments of the toxicity of stream water in the Clark Fork and Boulder River drainages were conducted to help identify sources of toxic metals and to describe the magnitude of the toxicity. This information helped the Department compete for reclamation funds available through the Resource Indemnity Trust Program and is also being used by consultants developing reclamation plans through the Abandoned Mine Lands Reclamation Program and the Clark Fork River Superfund Program. 
(2) The influence of streamflows on diurnal dissolved oxygen trends in various streams in the Upper Missouri River drainage was determined during the drought year of 1985. This information documents the need for maintaining instream flow in the drainage and may be used to support our instream flow reservation request.

(3) Seasonal and diurnal changes in the water chemistry of Hamby Lake in the Beaverhead Mountains were evaluated to determine how time of day and time of year influence lake chemistry. Baseline water chemistry survevs to assess acid deposition usually involve collection of only one sample. Interpretation of results could be biased if seasonal and diurnal variations in water chemistry are not considered.

(4) Baseline water chemistry was determined for 20 lakes in the Spanish Peaks Wilderness. Information will be used as a yardstick against which to gauge changes in lake chemistry that may occur in the future.

(5) An inventory of fishery habitat was conducted in various reaches of the Clark Fork River during the drought year of 1985. A question often raised concerning fish distribution in the upper Clark Fork River is whether reduced fish densities are due to degraded water quality or poor quality habitat.

(6) Residues of chlorinated hydrocarbon pesticides were determined in fishes from several Montana waters including Flathead Lake, Bighorn River near Fort Smith, Missouri River near Carter Ferry, and Clark Fork River near 
0

○

- 
Plains. Fish from several locations are analyzed each year to determine whether fish are safe for Montana sportsmen to eat.

(7) Supersaturation of dissolved gases was monitored in the Missouri River downstream of Hauser Dam in May of 1985 because sportsmen had reported catching fish suffering from gas bubble trauma. Several patterns of water release from the dam were tested to determine if the problem could be operationally controlled. 
-

○

- 
Two Montana rivers where acid mine drainage is believed to be limiting fish populations include the Boulder River in Jefferson County and the Clark Fork River from Warm Springs to its confluence with Rock Creek.

\section{Boulder River Drainage}

Metals enter the Boulder River from several tributaries including Cataract, High Ore, and Basin Creeks. Metals originate from diffuse mine tailings and from: acid seeps associated with inactive mine adits. Zinc appears to be the limiting metal in the Boulder drainage although copper is also present at concentrations that would be expected to have toxicological significance (Phillips and Hill 1986). Bioassays were conducted to identify sources of metals, document toxicity, and to help the Department assess priorities for seeking reclamation funding.

\section{Clark Fork River Drainage}

In recent years a great deal of effort has been expended trying to determine how mining and smelting wastes generated in the Butte-Anaconda area have influenced the ecology of the upper Clark Fork River. Contamination from these sources have resulted in the entire upper river being designated as a superfund site. Part of that effort has been directed towards understanding those factors that limit the distribution and abundance of brown trout in the river. 
-

○

○ 
The density of brown trout in some segments of the river, most notably between Deer Lodge and Rock Creek, are judged to be lower than would be expected in a healthy trout stream. Researchers have hypothesized that chronic toxicity caused by copper and zinc are responsible for lower densities of trout. Previous monitoring efforts have demonstrated that concentrations of several metals exceed criteria for protection of aquatic life (Phillips 1985). In particular, copper and zinc are present during certain seasons of the year at concentrations that have proven in laboratory tests to be chronically toxic to trout.

The Environmental Protection Agency attempted to evaluate the toxicity of Clark Fork River water to trout during spring of 1985 (Parrish and Rodriguez 1986). A continuous flow bioassay was conducted in the Deer Lodge area during which early life stages of rainbow trout were exposed to various dilutions of Clark Fork River water; dilution water was obtained from a local creek that is not contaminated with metals. Bioassay water was pumped from the river, hence the test fish were subject to the ambient fluctuations in metals concentrations that occur naturally. Unfortunately, spring runoff during the 1985 water year was much lower than normal, consequently the concentrations of metals in the river were uncharacteristically low. Results of the tests were inconclusive. Accordingly, we conducted instream toxicity tests at various locations in the Clark Fork River drainage during the spring of 1986 to try and gain additional information on the toxicity of the Clark Fork River water to trout. 
Methods

\section{Boulder River Drainage}

Bioassays in the Boulder River drainage began on May 8 and ended on June 27 , 1986. Fingerling rainbow trout were held at six locations in the drainage including near the mouths of High Ore, Basin, and Cataract Creeks; in the Boulder River upstream of all three tributaries (control site); in the Boulder River downstream of Basin and Cataract Creeks but upstream of High Ore Creek; and in the Boulder River downstream of all three tributaries (Fig. 1). At each site trout were held in two identical $45 \mathrm{~cm}$ sections of $31 \mathrm{~cm}$ diameter PVC pipe with $3 \mathrm{~mm}$ mesh nylon netting stretched over each end. Forty trout were placed in each vessel at the beginning, i.e., a total of $80 \mathrm{fish}$ began the test at each site. At some locations difficulty was experienced with sediment entering the holding tanks resulting in problems with escapement during mortality monitoring. Because of this, a second set of tests was begun at two of the sites (mainstem Boulder River above and below High Ore Creek) on May 23, 1986. Fish that escaped were not included in calculations of percentage rate of mortality.

Mortality was monitored approximately three times per week and total alkalinity, hardness, $\mathrm{pH}$, and total recoverable copper and zinc were measured weekly at each site. Metals concentrations were determined from a composite sample ( 3 samples per week per composite) except for a brief period towards the end of May when each sample was analyzed individually. Streamflow was measured weekly during the tests in Basin, High Ore, and Cataract Creeks using a Price Current Meter. Metals loading at the mouth of each of the tributaries was calculated by multiplying stream discharge rate by concentrations of total recoverable copper or 
-

-

- 


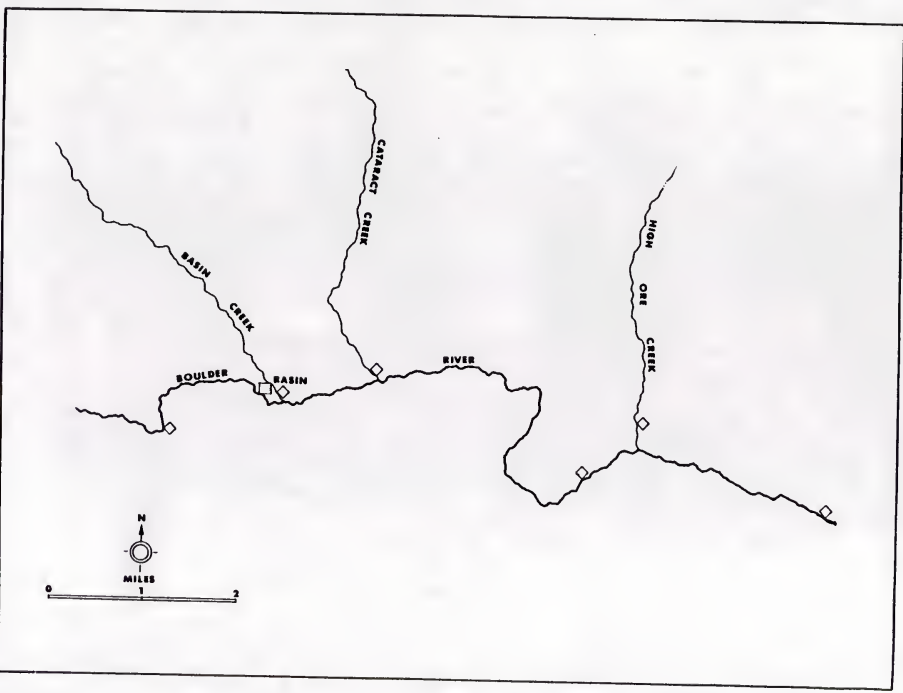

Figure 1. Map of the Upper Boulder River; diamonds indicate bioassay sites. 
zinc. Total recoverable zinc and streamflow measurements were also taken at several locations in the Basin Creek drainage in August and September to try and identify sources of zinc to the creek.

\section{Clark Fork River Drainage}

Bioassays in the Clark Fork River began on April 18 and ended on June 26, 1986. Fingerling rainbow trout were kept in the drainage at seven locations including Silver Bow Creek where it crosses Interstate Highway 90, Silver Bow Creek downstream of the confluence of the Pond-2 discharge and the Mill-Willow bypass, Racetrack Creek near its mouth (control site), Clark Fork River near Deer Lodge, Clark Fork River near Gold Creek, Clark Fork River near Bearmouth, and Clark Fork River near Clinton (Fig. 2). At each site except Silver Bow Creek, trout were held in two identical floating vessels constructed with a wooden frame and $3 \mathrm{~mm}$ mesh nylon netting. Each bioassay vessel contained about 40 fingerling trout, thus approximately 80 trout were held at each site. The Silver Bow Creek site was added at the last minute because there were a few trout left after other sites had been supplied. Fingerling rainbow trout in Silver Bow Creek were kept in an $45 \mathrm{~cm}$ section of $31 \mathrm{~cm}$ diameter PVC pipe with $3 \mathrm{~mm}$ mesh nylon netting stretched over each end (similar to the holding vessels used in the Boulder River study). Only 18 trout began the test in Silver Bow Creek.

During the test, mortality was monitored on three times each week and alkalinity, hardness and $\mathrm{pH}$ were measured weekly. Additionally, water samples were collected three times each week and analyzed for total recoverable copper 


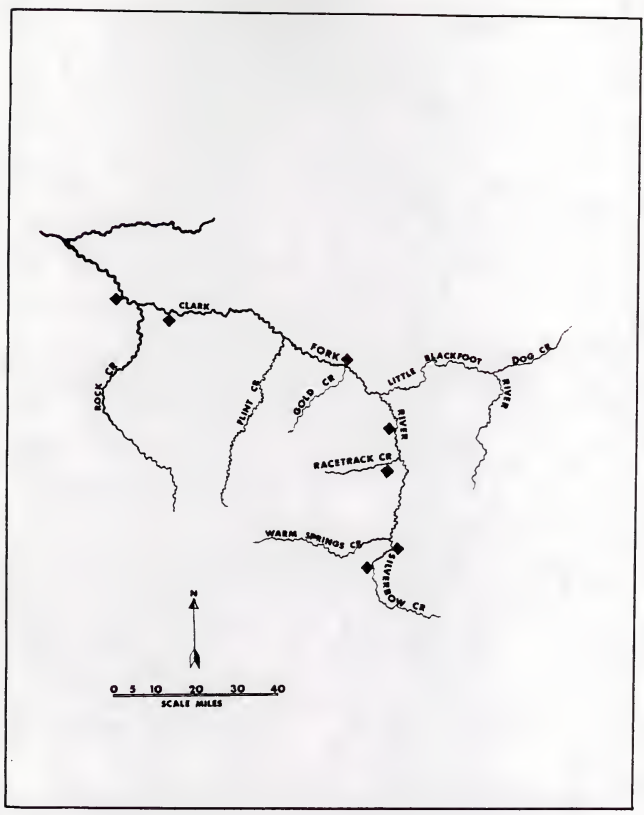

Figure 2. Map of the Upper Clark Fork River drainage; diamonds indicate bioassay locations. 
and zinc. Water samples for a given week were composited during the majority of the test but were analyzed individually during the peak of runoff in late May and early June.

Streamflow records were obtained from the U.S. Geological Survey for Silver Bow Creek, Clark Fork River near Warm Springs, Clark Fork River near Deer Lodge, Clark Fork River near Gold Creek, Clark Fork River near Bearmouth, and Clark Fork River near Clinton. Metals loading of copper or zinc (expressed as kg/day) was calculated by multiplying streamflow by metals concentration (using the appropriate conversion factors).

\section{Results}

\section{Boulder River}

Alkalinity, hardness and $\mathrm{pH}$ values (Table 1) were similar to those measured in 1985 (Phillips and Hill 1986). The majority of the drainage is characterized by low alkalinity, low hardness and neutral pH waters typical of those draining the granitic soils of the Boulder Batholith. The water in High Ore Creek is harder and somewhat more alkaline than the other bioassay locations probably because of the presence of limestone in the basin. The low buffering capacity and hardness increases the vulnerability of fishes in the drainage to metals toxicity.

\section{Metals concentrations and loading}

During the bioassays zinc concentrations averaged approximately $0.1,0.2$, and $1.7 \mathrm{mg} / 1$ respectively in Basin, Cataract, and High Ore Creeks (Fig. 3 ) or 
Table 1. Alkalinity, hardness and pH at several locations in the Boulder River drainage.

\begin{tabular}{|c|c|c|c|c|c|c|c|c|c|c|c|c|}
\hline \multirow{2}{*}{ Location } & \multirow[t]{2}{*}{$\mathrm{n}$} & \multicolumn{3}{|c|}{$\begin{array}{c}\text { Total alkalinity } \\
\mathrm{mg} / 1 \text { as } \mathrm{CaCO}_{3}\end{array}$} & \multirow{2}{*}{\multicolumn{4}{|c|}{$\begin{array}{l}\text { Hardness } \\
\mathrm{mg} / \mathrm{l} \text { as } \mathrm{CaCO}_{3}\end{array}$}} & \multicolumn{4}{|c|}{$\mathrm{pH}$} \\
\hline & & mean & range & SD & $n$ & mean & & & $\bar{n}$ & mean & range & SD \\
\hline \multicolumn{13}{|l|}{ Mainstem Boulder River } \\
\hline Above Basin & 7 & 34.6 & $21-46$ & \pm 7.8 & 8 & 31.3 & $20-40$ & \pm 7.0 & 5 & 7.1 & $6.9-7.4$ & \pm 0.20 \\
\hline Above High Ore Creek & 7 & 32.6 & $26-46$ & \pm 6.5 & 8 & 27.8 & $20-36$ & \pm 5.8 & 5 & 7.4 & $7.2-7.8$ & \pm 0.28 \\
\hline Below High Ore Creek & 6 & 31.0 & $22-42$ & \pm 6.9 & 7 & 29.7 & $24-36$ & \pm 4.7 & 3 & 7.6 & $7.2-8.1$ & \pm 0.47 \\
\hline \multicolumn{13}{|l|}{ Tributaries -- Boulder River } \\
\hline Basin Creek & 7 & 20.0 & $14-26$ & \pm 4.6 & 8 & 18.5 & $14-24$ & \pm 3.7 & 5 & 7.2 & $6.9-7.7$ & \pm 0.33 \\
\hline Cataract Creek & 7 & 26.0 & $20-36$ & \pm 6.0 & 8 & 28.0 & $20-38$ & \pm 5.9 & 5 & 7.2 & $7.1-7.5$ & \pm 0.18 \\
\hline High Ore Creek & 7 & 64.6 & $48-84$ & \pm 13.2 & 8 & 108.5 & $72-156$ & \pm 26.6 & 5 & 7.8 & $7.6-8.1$ & \pm 0.19 \\
\hline
\end{tabular}

$\mathrm{KH} / \mathrm{vg}-118 \mathrm{a}-1$ 


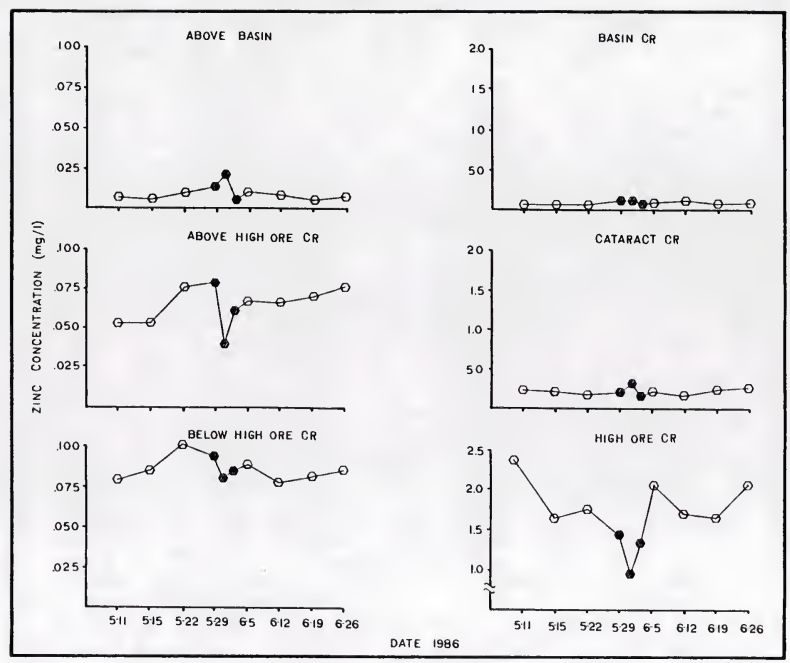

Figure 3. Total recoverable zinc concentrations at bioassay sites in the Boulder River drainage. 
approximately 5-, 10- and 85-fold the values recommended for protection of aquatic life (USEPA 1985b). Comparatively, copper concentrations averaged 0.1, 0.3 , and $0.5 \mathrm{mg} / 1$ respectively in Basin, High Ore, and Cataract Creeks (Fig. 4) exceeding the values recommended for protection of aquatic life (USEPA 1985a) by approximately 2-, 4- and 7-fold, respectively. Loading of both copper and zinc to the mainstem of the Boulder River from the tributaries was greatest from Cataract Creek, followed in decreasing order by Basin and High Ore Creeks (Tables 2 and 3). Phillips and Hill (1986) reported a similar trend for data collected during spring of 1985 .

All three tributaries contribute significant amounts of metals to the mainstem. Zinc and copper concentrations in the mainstem were measurably higher downstream of Basin and Cataract Creeks than above, and zinc concentrations in the mainstem increased downstream of High Ore Creek (Figs. 3 and 4). Neither copper or zinc were present at concentrations above those recommended for protection of aquatic life upstream of Basin. However, during the bioassay average zinc concentrations downstream of Cataract and High Ore Creeks were approximately 3- and 4-fold the criteria for protection of aquatic life. Similarly, copper concentrations at the same two locations averaged about 3-fold the criteria for protection of aquatic life.

Zinc loading measurements in the Basin Creek drainage showed that Jack Creek is the major source of zinc to the creek (Table 4). Acid drainage from historic mine tailings ponds is evident in the upper reaches of Jack Creek. 
0

-

○ 


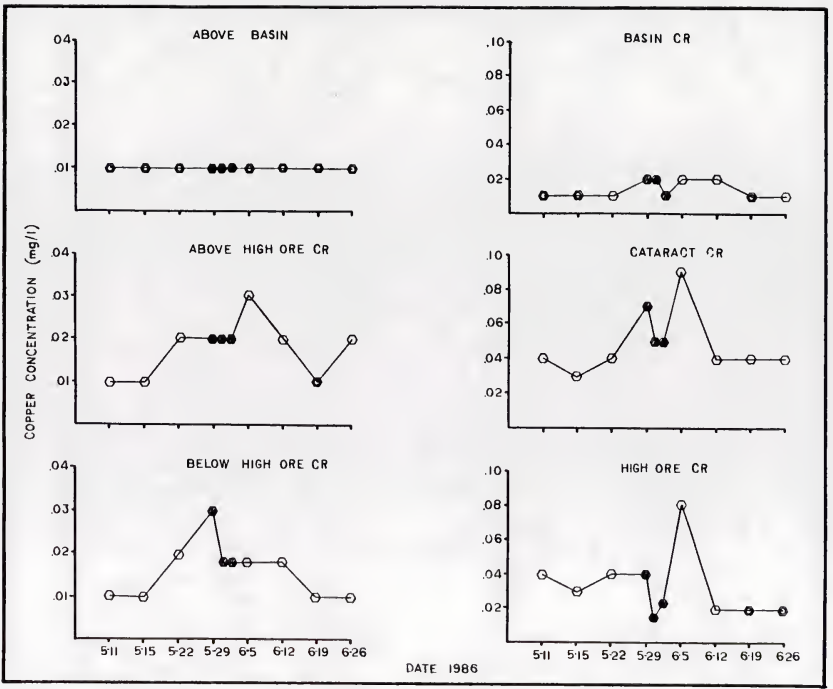

Figure 4. Total recoverable copper concentrations at bioassay sites in the Boulder River drainage. 
Table 2. Zinc loading at the mouths of Basin, Cataract and High Ore Creeks.

\begin{tabular}{lcrrrrrr}
\hline \multicolumn{7}{c}{ Zinc loading (kg/day) } \\
\hline Location & \multicolumn{7}{c}{ Date - 1986} \\
\cline { 2 - 7 } & $5 / 13$ & $5 / 20$ & $5 / 27$ & $6 / 3$ & $6 / 10$ & $6 / 17$ & $6 / 24$ \\
\hline Basin Creek & 12.1 & 14.5 & 47.8 & 28.8 & 24.8 & 8.9 & 5.0 \\
Cataract Creek & 17.2 & 35.2 & 85.0 & 83.6 & 24.0 & 12.7 & 13.2 \\
High 0re Creek & 10.4 & 10.3 & 12.0 & 38.8 & 14.5 & 6.5 & 6.3 \\
\hline
\end{tabular}

$\mathrm{KH} / \mathrm{vg}-116 \mathrm{a}-1$ 
○ 
Table 3. Copper loading at the mouths of Basin, Cataract, and High Ore Creeks.

\begin{tabular}{lccccccc}
\hline \multicolumn{7}{c}{ Copper loading (kg/day) } \\
\hline Location & \multicolumn{7}{c}{ Date - 1986} \\
\cline { 2 - 7 } & $5 / 13$ & $5 / 20$ & $5 / 27$ & $6 / 3$ & $6 / 10$ & $6 / 17$ & $6 / 24$ \\
\hline Basin Creek & 1.4 & - & 8.5 & 6.5 & 3.4 & - & 0.5 \\
Cataract Creek & 2.4 & 7.4 & 19.0 & 37.3 & 5.3 & 2.1 & 1.9 \\
High Ore Creek & 0.2 & 0.2 & 0.2 & 1.5 & 0.2 & - & - \\
\hline
\end{tabular}

$\mathrm{KH} / \mathrm{vg}-116 \mathrm{a}-2$ 
Table 4. Zinc loading at several locations in Basin Creek and Jack Creek.

\begin{tabular}{|c|c|c|c|}
\hline \multirow{3}{*}{ Location } & \multicolumn{2}{|c|}{ Zinc loading $(\mathrm{kg} /$ day $)$} & \\
\hline & \multicolumn{3}{|c|}{ Date -- 1986} \\
\hline & $8 / 25$ & $8 / 28$ & $9 / 3$ \\
\hline $\begin{array}{l}\text { Basin Creek above } \\
\text { Jack Creek }\end{array}$ & 0.05 & 0.06 & 0.07 \\
\hline Jack Creek & 2.77 & 4.21 & 4.10 \\
\hline $\begin{array}{l}\text { Basin Creek below } \\
\text { Jack Creek }\end{array}$ & 1.38 & 1.13 & 1.97 \\
\hline $\begin{array}{l}\text { Basin Creek } 2 \mathrm{mi} \text {. } \\
\text { above its mouth }\end{array}$ & 0.96 & 0.83 & 1.31 \\
\hline $\begin{array}{l}\text { Basin Creek at } \\
\text { its mouth }\end{array}$ & 0.33 & 0.56 & 1.01 \\
\hline
\end{tabular}


-

-

○ 
Bioassay results

Water in all three tributaries to the Boulder River was highly toxic to trout. All of the fish held in High Ore and Cataract Creeks were dead within a week as were over $90 \%$ of the fish held in Bas in Creek (Fig. 5 and Tables 5-7). The remaining few fish kept in Basin Creek were able to survive throughout the test.

In the mainstem, no mortality occurred at the control site upstream of Basin (Fig. 5 and Table 8) but mortality occurred downstream of the tributaries (Figs. 6-7 and Tables 9-12). For the tests that began on May 8, cumulative mortality by the end of the test was $19 \%$ at the mainstem site downstream of Cataract Creek and $61 \%$ downstream of High Ore Creek (Fig. 6 and Tables 9-10); all mortalities occurred during the first two weeks of the test. Cumulative mortality at the end of the test initiated on May 23 was $28 \%$ below Cataract Creek and $45 \%$ below High Ore Creek (Fig. 7 and Tables 11-12).

Measured concentrations of both copper and zinc in the tributaries were in a range reported to be toxic to rainbow trout during laboratory experiments (Garton 1972; Chapman 1978; Miller and McKay 1980). Concentrations in the mainstem were also above those reported to be acutely toxic but near the lower range where acute toxicity has been observed.

The bioassay locations represent a gradient of severity of exposure to metals. Metals concentrations are sufficiently high to prevent fish from living in either High Ore or Cataract Creeks but are lower in Bas in Creek where some fish are present. Comparatively, trout are abundant in the Boulder River upstream of 
○ 


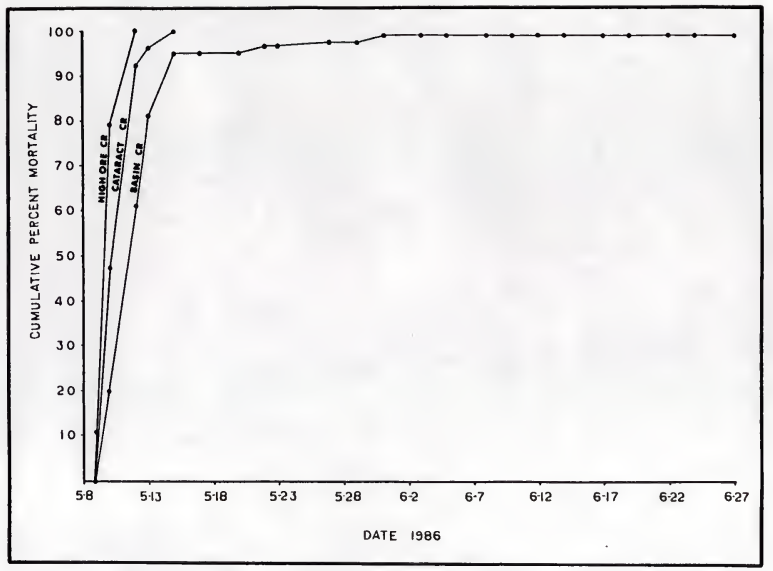

Figure 5. Cumulative percent mortality of fingerling rainbow trout kept in Basin, High Ore, and Cataract Creeks. 
Table 5. Results of instream bioassays using fingerling rainbow trout in High Ore Creek near its mouth.

\begin{tabular}{|c|c|c|c|c|c|c|c|c|c|}
\hline \multirow[t]{2}{*}{$\begin{array}{l}\text { Date } \\
(1986)\end{array}$} & \multicolumn{2}{|c|}{$\begin{array}{l}\text { Number } \\
\text { in test }\end{array}$} & \multicolumn{2}{|c|}{$\begin{array}{c}\text { Number } \\
\text { dead }\end{array}$} & \multirow{2}{*}{\multicolumn{2}{|c|}{$\begin{array}{r}\begin{array}{r}\text { Cumulative } \\
\text { number dead }\end{array} \\
A\end{array}$}} & \multicolumn{3}{|c|}{$\begin{array}{l}\text { Cumulative percent } \\
\text { mortality }\end{array}$} \\
\hline & & & & $\bar{B}$ & & & $\bar{A}$ & $B$ & $A$ and $B$ \\
\hline $5 / 8$ & 40 & 40 & - & - & - & - & - & - & - \\
\hline $5 / 9$ & 37 & 37 & 6 & 3 & 6 & 3 & 15.0 & 7.5 & 11.3 \\
\hline $5 / 10$ & 10 & 7 & 24 & 30 & 30 & 33 & 75.0 & 82.5 & 78.8 \\
\hline $5 / 12$ & 0 & 0 & 7 & 7 & 40 & 40 & 100.0 & 100.0 & 100.0 \\
\hline
\end{tabular}


Table 6. Results of instream bioassays using fingerling rainbow trout in Cataract Creek near its mouth.

\begin{tabular}{|c|c|c|c|c|c|c|c|c|c|}
\hline \multirow[t]{2}{*}{$\begin{array}{l}\text { Date } \\
(1986)\end{array}$} & \multirow{2}{*}{\multicolumn{2}{|c|}{$\begin{array}{l}\text { Number } \\
\text { in test } \\
\frac{B}{B}\end{array}$}} & \multicolumn{2}{|c|}{$\begin{array}{l}\text { Number } \\
\text { dead }\end{array}$} & \multirow{2}{*}{\multicolumn{2}{|c|}{$\begin{array}{r}\text { Cumulative } \\
\text { number dead } \\
A \quad B\end{array}$}} & \multicolumn{3}{|c|}{$\begin{array}{c}\text { Cumulative percent } \\
\text { mortality }\end{array}$} \\
\hline & & $\bar{B}$ & & & & & $A$ & & $A$ and $B$ \\
\hline $5 / 8$ & 40 & 40 & - & - & - & - & - & - & - \\
\hline $5 / 9$ & 40 & 39 & 0 & 1 & 0 & 1 & 0.0 & 2.5 & 1.3 \\
\hline $5 / 10$ & 33 & 9 & 7 & 30 & 7 & 3 & 17.5 & 77.5 & 47.5 \\
\hline $5 / 12$ & $7^{a}$ & 0 & 26 & 9 & 33 & 40 & 84.6 & 100.0 & 92.4 \\
\hline $5 / 13$ & 3 & 0 & 3 & 0 & 36 & 40 & 92.3 & 100.0 & 96.2 \\
\hline $5 / 15$ & 0 & 0 & 3 & 0 & 39 & 40 & 100.0 & 100.0 & 100.0 \\
\hline
\end{tabular}

ane fish escaped on 12. May. Cumulative percent mortality for subsequent dates was calculated using the total number of fish remaining. 
0

.

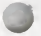


Table 7. Results of instream bloassays using fingerling rainbow trout in the Basin Creek near its mouth.

\begin{tabular}{|c|c|c|c|c|c|c|c|c|c|}
\hline \multirow[t]{2}{*}{$\begin{array}{l}\text { Date } \\
(1986)\end{array}$} & \multirow{2}{*}{\multicolumn{2}{|c|}{$\begin{array}{l}\text { Number } \\
\text { in test } \\
A \quad B\end{array}$}} & \multirow{2}{*}{\multicolumn{2}{|c|}{$\begin{array}{c}\text { Number } \\
\text { dead } \\
A \quad B\end{array}$}} & \multirow{2}{*}{\multicolumn{2}{|c|}{$\begin{array}{r}\begin{array}{r}\text { Cumulative } \\
\text { number dead }\end{array} \\
A\end{array}$}} & \multicolumn{3}{|c|}{$\begin{array}{c}\text { Cumulative Percent } \\
\text { mortality }\end{array}$} \\
\hline & & & & & & & $A$ & B & $A$ and $B$ \\
\hline $5 / 8$ & 40 & 40 & - & - & - & - & - & - & - \\
\hline $5 / 9$ & 40 & 40 & 0 & 0 & 0 & 0 & 0.0 & 0.0 & 0.0 \\
\hline $5 / 10$ & 31 & 33 & 9 & 7 & 9 & 7 & 22.5 & 17.5 & 2.0 .0 \\
\hline $5 / 12$ & 15 & 16 & 16 & 17 & 25 & 24 & 62.5 & 60.0 & 61.3 \\
\hline $5 / 13$ & 6 & 9 & 9 & 7 & 34 & 31 & 85.0 & 77.5 & 81.3 \\
\hline $5 / 15$ & 3 & $1^{a}$ & 3 & 7 & 37 & 38 & 92.5 & 97.4 & 94.9 \\
\hline $5 / 17$ & 3 & 1 & 0 & 0 & 37 & 38 & 92.5 & 97.4 & 94.9 \\
\hline $5 / 20$ & 3 & 1 & 0 & 0 & 37 & 38 & 92.5 & 97.4 & 94.9 \\
\hline $5 / 22$ & 2 & 1 & 1 & 0 & 38 & 38 & 95.0 & 97.4 & 96.2 \\
\hline $5 / 23$ & 2 & 1 & 0 & 0 & 38 & 38 & 95.0 & 97.4 & 96.2 \\
\hline $5 / 27$ & 2 & $0^{a}$ & 0 & 0 & 38 & 38 & 95.0 & 100.0 & 97.4 \\
\hline $5 / 29$ & 2 & 0 & 0 & 0 & 38 & 38 & 95.0 & 100.0 & 97.4 \\
\hline $5 / 31$ & 1 & 0 & 1 & 0 & 39 & 38 & 97.5 & 100.0 & 98.7 \\
\hline $6 / 3$ & 1 & 0 & 0 & 0 & 39 & 38 & 97.5 & 100.0 & 98.7 \\
\hline $6 / 5$ & 1 & 0 & 0 & 0 & 39 & 38 & 97.5 & 100.0 & 98.7 \\
\hline $6 / 8$ & 1 & 0 & 0 & 0 & 39 & 38 & 97.5 & 100.0 & 98.7 \\
\hline $6 / 10$ & 1 & 0 & 0 & 0 & 39 & 38 & 97.5 & 100.0 & 98.7 \\
\hline $6 / 12$ & 1 & 0 & 0 & 0 & 39 & 38 & 97.5 & 100.0 & 98.7 \\
\hline $6 / 14$ & 1 & 0 & 0 & 0 & 39 & 38 & 97.5 & 100.0 & 98.7 \\
\hline $6 / 17$ & 1 & 0 & 0 & 0 & 39 & 38 & 97.5 & 100.0 & 98.7 \\
\hline $6 / 19$ & 1 & 0 & 0 & 0 & 39 & 38 & 97.5 & 100.0 & 98.7 \\
\hline $6 / 22$ & 1 & 0 & 0 & 0 & 39 & 38 & 97.5 & 100.0 & 98.7 \\
\hline $6 / 24$ & 1 & 0 & 0 & 0 & 39 & 38 & 97.5 & 100.0 & 98.7 \\
\hline $6 / 27$ & 1 & 0 & 0 & 0 & 39 & 38 & 97.5 & 100.0 & 98.7 \\
\hline
\end{tabular}

${ }^{a}$ One fish escaped on 15 May and on 27 May. Cumulative percent mortality for subsequent dates was calculated using the total number of fish remaining. 
○

. 
Table 8. Results of instream bioassays using fingerling rainbow trout in the Boulder River upstream of the town of Basin.

\begin{tabular}{|c|c|c|c|c|c|c|c|c|c|}
\hline \multirow[t]{2}{*}{$\begin{array}{c}\text { Date } \\
(1986)\end{array}$} & \multicolumn{2}{|c|}{$\begin{array}{r}\text { Number } \\
\text { in test }\end{array}$} & \multicolumn{2}{|c|}{$\begin{array}{c}\text { Number } \\
\text { dead }\end{array}$} & \multirow{2}{*}{\multicolumn{2}{|c|}{$\begin{array}{l}\text { Cumulative } \\
\text { number dead }\end{array}$}} & \multicolumn{3}{|c|}{$\begin{array}{c}\text { Cumulative percent } \\
\text { mortality }\end{array}$} \\
\hline & & 8 & & $B$ & $A$ & & $\bar{A}$ & $B$ & $A$ and $B$ \\
\hline $5 / 8$ & 40 & 40 & - & - & - & - & - & - & - \\
\hline $5 / 9$ & 40 & 40 & 0 & 0 & 0 & 0 & 0.0 & 0.0 & 0 \\
\hline $5 / 10$ & 40 & 40 & 0 & 0 & 0 & 0 & 0.0 & 0.0 & 0 \\
\hline $5 / 12$ & 40 & 40 & 0 & 0 & 0 & 0 & 0.0 & 0.0 & 0 \\
\hline $5 / 13$ & 40 & 40 & 0 & 0 & 0 & 0 & 0.0 & 0.0 & 0 \\
\hline $5 / 15$ & 40 & 40 & 0 & 0 & 0 & 0 & 0.0 & 0.0 & 0 \\
\hline $5 / 17$ & 40 & 40 & 0 & 0 & 0 & 0 & 0.0 & 0.0 & 0 \\
\hline $5 / 20$ & 40 & 40 & 0 & 0 & 0 & 0 & 0.0 & 0.0 & 0 \\
\hline $5 / 22$ & 40 & 40 & 0 & 0 & 0 & 0 & 0.0 & 0.0 & 0 \\
\hline $5 / 23$ & 40 & 40 & 0 & 0 & 0 & 0 & 0.0 & 0.0 & 0 \\
\hline $5 / 27$ & $0^{a}$ & $20^{a}$ & - & 0 & - & 0 & - & 0.0 & 0 \\
\hline $5 / 29$ & 0 & 20 & - & 0 & - & 0 & - & 0.0 & 0 \\
\hline $5 / 31$ & 0 & $12^{a}$ & - & 0 & - & 0 & - & 0.0 & 0 \\
\hline $6 / 3$ & 0 & $0^{a}$ & - & 0 & - & 0 & - & 0.0 & 0 \\
\hline
\end{tabular}

${ }^{a}$ Handling problems due to siltation allowed fish to escape on several occasions. No mortalities were observed in either treatment during the test. 
0

○

- 


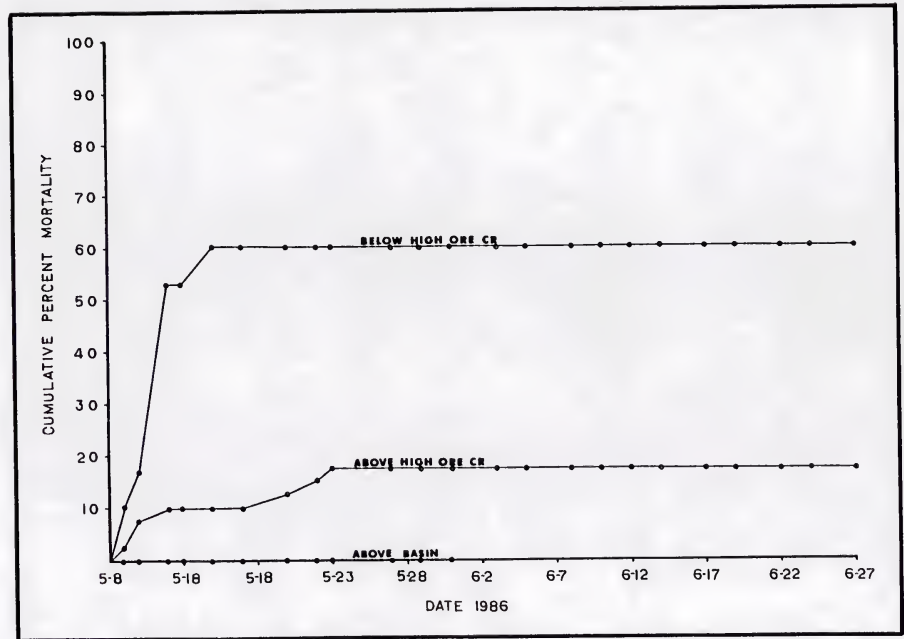

Figure 6. Cumulative percent mortaility of fingerling rainbow trout kept in Basin, High Ore, and Cataract Creeks. 


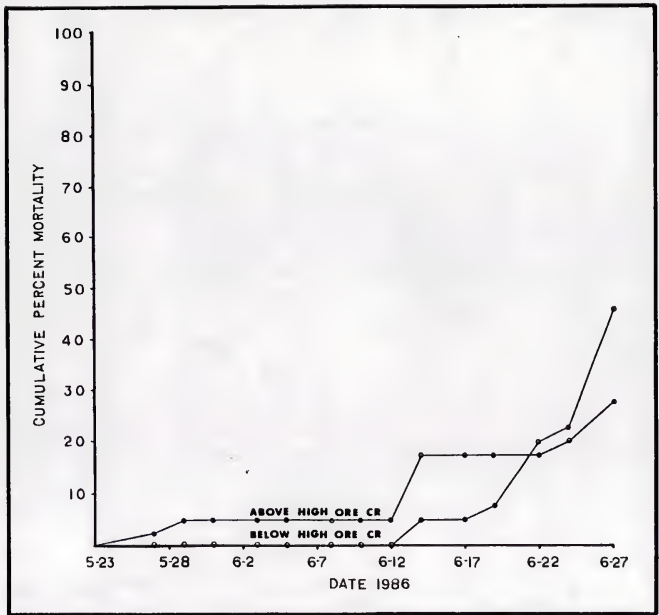

Figure 7. Cumulative percent mortality of rainbow trout kept in the Boulder River above and below High Ore Creek. 
Table 9. Results of instream bloassays using fingerling rainbow trout in the Boulder River upstream of High Ore Creek.

\begin{tabular}{|c|c|c|c|c|c|c|c|c|c|}
\hline \multirow[t]{2}{*}{$\begin{array}{l}\text { Date } \\
(1986)\end{array}$} & \multicolumn{2}{|c|}{$\begin{array}{r}\text { Number } \\
\text { in test }\end{array}$} & \multicolumn{2}{|c|}{$\begin{array}{l}\text { Number } \\
\text { dead }\end{array}$} & \multicolumn{2}{|c|}{$\begin{array}{l}\text { Cumulat ive } \\
\text { number dead }\end{array}$} & \multicolumn{3}{|c|}{$\begin{array}{c}\text { Cumulative percent } \\
\text { mortality }\end{array}$} \\
\hline & & & & & & & $A$ & B & $A$ and $B$ \\
\hline $5 / B$ & 40 & 40 & - & - & - & - & - & - & - \\
\hline $5 / 9$ & 39 & 40 & 1 & 0 & 1 & 0 & 2.5 & 0.0 & 1.3 \\
\hline $5 / 10$ & 37 & 37 & 2 & 3 & 3 & 3 & 7.5 & 7.5 & 7.5 \\
\hline $5 / 12$ & 36 & 30 & 1 & 7 & 4 & 10 & 10.0 & 25.0 & 17.5 \\
\hline $5 / 13$ & 36 & 30 & 0 & 0 & 4 & 10 & 10.0 & 25.0 & 17.5 \\
\hline $5 / 15$ & 36 & 29 & 0 & 1 & 4 & 11 & 10.0 & 27.5 & 18.8 \\
\hline $5 / 17$ & 36 & 29 & 0 & 0 & 4 & 11 & 10.0 & 27.5 & IB. B \\
\hline $5 / 20$ & 35 & $10^{a}$ & 1 & - & 5 & - & 12.5 & - & - \\
\hline $5 / 22$ & 34 & - & 1 & - & 6 & - & 15.0 & - & - \\
\hline $5 / 23$ & 33 & - & 1 & - & 7 & - & 17.5 & - & - \\
\hline $5 / 27$ & 33 & - & 0 & - & 7 & - & 17.5 & - & - \\
\hline $5 / 29$ & 33 & - & 0 & - & 7 & - & 17.5 & - & - \\
\hline $5 / 31$ & 33 & - & 0 & - & 7 & - & 17.5 & - & - \\
\hline $6 / 3$ & 33 & - & 0 & - & 7 & - & 17.5 & - & - \\
\hline $6 / 5$ & 33 & - & 0 & - & 7 & - & 17.5 & - & - \\
\hline $6 / B$ & 33 & - & 0 & - & 7 & - & 17.5 & - & - \\
\hline $6 / 10$ & 33 & - & 0 & - & 7 & - & 17.5 & - & - \\
\hline $6 / 12$ & 33 & - & 0 & - & 7 & - & 17.5 & - & - \\
\hline $6 / 14$ & 33 & - & 0 & - & 7 & - & 17.5 & - & - \\
\hline $6 / 17$ & 33 & - & 0 & - & 7 & - & 17.5 & - & - \\
\hline $6 / 19$ & 33 & - & 0 & - & 7 & - & 17.5 & - & - \\
\hline $6 / 22$ & 33 & - & 0 & - & 7 & - & 17.5 & - & - \\
\hline $6 / 24$ & 33 & - & 0 & - & 7 & - & 17.5 & - & - \\
\hline $6 / 27$ & 33 & - & 0 & - & 7 & - & 17.5 & - & - \\
\hline
\end{tabular}

a Handling problems due to siltation allowed 10 fish to escape on 22 May. Replicate B was terminated and replicate $A$ was used to plot cumulative percent mortality. 
O

0

0 
Table 10. Results of Instream bloassays using fingerling rainbow trout in the Boulder River downstream of High Ore Creek.

\begin{tabular}{|c|c|c|c|c|c|c|c|c|c|}
\hline \multirow[t]{2}{*}{$\begin{array}{l}\text { Date } \\
(1986)\end{array}$} & \multirow{2}{*}{\multicolumn{2}{|c|}{$\begin{array}{l}\text { Number } \\
\text { in test } \\
\text { B }\end{array}$}} & \multicolumn{2}{|c|}{$\begin{array}{c}\text { Number } \\
\text { dead }\end{array}$} & \multirow{2}{*}{\multicolumn{2}{|c|}{$\begin{array}{l}\text { Cumulat ive } \\
\text { number dead } \\
A\end{array}$}} & \multicolumn{3}{|c|}{$\begin{array}{l}\text { Cumulative percent } \\
\text { mortality }\end{array}$} \\
\hline & & & & & & & $A$ & B & $A$ and $B$ \\
\hline $5 / 8$ & 20 & 19 & - & - & - & - & - & - & - \\
\hline $5 / 9$ & 17 & 18 & 3 & 1 & 3 & 1 & 15.0 & 5.3 & 10.3 \\
\hline $5 / 10$ & $13^{a}$ & 17 & 1 & 1 & 4 & $?$ & 23.5 & 10.5 & 16.7 \\
\hline $5 / 12$ & 8 & 7 & 5 & 10 & 9 & 12 & 52.9 & 63.2 & 58.3 \\
\hline $5 / 13$ & 8 & 7 & 0 & 0 & 9 & 12 & 52.9 & 63.2 & 58.3 \\
\hline $5 / 15$ & 8 & 6 & 0 & 1 & 9 & 13 & 52.9 & 68.4 & 61.1 \\
\hline $5 / 17$ & 8 & 6 & 0 & 0 & 9 & 13 & 52.9 & 68.4 & 61.1 \\
\hline $5 / 20$ & 8 & 6 & 0 & 0 & 9 & 13 & 52.9 & 68.4 & 61.1 \\
\hline $5 / 22$ & 8 & 6 & 0 & 0 & 9 & 13 & $5 ? .9$ & 68.4 & 61.1 \\
\hline $5 / 23$ & 8 & 6 & 0 & 0 & 9 & 13 & 52.9 & 68.4 & 61.1 \\
\hline $5 / 27$ & 8 & 6 & 0 & 0 & 9 & 13 & 52.9 & 68.4 & 61.1 \\
\hline $5 / 29$ & 8 & 6 & 0 & 0 & 9 & 13 & 52.9 & 68.4 & 61.1 \\
\hline $5 / 31$ & 8 & 6 & 0 & 0 & 9 & 13 & 52.9 & 68.4 & 61.1 \\
\hline $6 / 3$ & 8 & 6 & 0 & 0 & 9 & 13 & 52.9 & 68.4 & 61.1 \\
\hline $6 / 5$ & 8 & 6 & 0 & 0 & 9 & 13 & 52.9 & 68.4 & 61.1 \\
\hline $6 / 8$ & 8 & 6 & 0 & 0 & 9 & 13 & 52.9 & 68.4 & 61.1 \\
\hline $6 / 10$ & 8 & 6 & 0 & 0 & 9 & 13 & 52.9 & 68.4 & 61.1 \\
\hline $6 / 12$ & 8 & 6 & 0 & 0 & 9 & 13 & 52.9 & 68.4 & 61.1 \\
\hline $6 / 14$ & 8 & 6 & 0 & 0 & 9 & 13 & 52.9 & 68.4 & 61.1 \\
\hline $6 / 17$ & 8 & 6 & 0 & 0 & 9 & 13 & 52.9 & 68.4 & 61.1 \\
\hline $6 / 19$ & 8 & 6 & 0 & 0 & 9 & 13 & 52.9 & 68.4 & 61.1 \\
\hline $6 / 22$ & 8 & 6 & 0 & 0 & 9 & 13 & 52.9 & 68.4 & 61.1 \\
\hline $6 / 24$ & 8 & 6 & 0 & 0 & 9 & 13 & 52.9 & 68.4 & 61.1 \\
\hline $6 / 27$ & 8 & 6 & 0 & 0 & 9 & 13 & 52.9 & 68.4 & 61.1 \\
\hline
\end{tabular}

ahree fish escaped on 10 May. Cumulative percent mortality for subsequent dates was calculated using the total number of fish remaining. 
Table 11. Pesults of instream bioassays using fingerling rainbow trout in the Boulder River upstrean of High Ore Creek.

\begin{tabular}{|c|c|c|c|c|c|c|c|c|c|}
\hline \multirow[t]{2}{*}{$\begin{array}{l}\text { Nate } \\
(1986)\end{array}$} & \multirow{2}{*}{\multicolumn{2}{|c|}{$\begin{array}{r}\text { Number } \\
\text { in test } \\
A \quad B\end{array}$}} & \multirow{2}{*}{\multicolumn{2}{|c|}{ 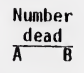 }} & \multirow{2}{*}{\multicolumn{2}{|c|}{$\begin{array}{c}\text { Cumulative } \\
\text { number dead } \\
A \quad B\end{array}$}} & \multicolumn{3}{|c|}{$\begin{array}{c}\text { Cumulative percent } \\
\text { mortality }\end{array}$} \\
\hline & & & & & & & A & B & $A$ and $B$ \\
\hline $5 / 23$ & 40 & 40 & - & - & - & - & - & - & - \\
\hline $5 / 27$ & 38 & 39 & 2 & 1 & 2 & 1 & 5.0 & 2.5 & 3.8 \\
\hline $5 / 29$ & 36 & 38 & 2 & 1 & 4 & 2 & 10.0 & 5.0 & 7.5 \\
\hline $5 / 31$ & 36 & 38 & 0 & 0 & 4 & 2 & 10.0 & 5.0 & 7.5 \\
\hline $6 / 3$ & $0^{a}$ & 38 & - & 0 & - & 2 & - & 5.0 & - \\
\hline $6 / 5$ & -- & 38 & - & 0 & - & 2 & - & 5.0 & - \\
\hline $6 / 8$ & -- & 38 & - & 0 & - & 2 & - & 5.0 & - \\
\hline $6 / 10$ & -- & 38 & - & 0 & - & 2 & - & 5.0 & - \\
\hline $6 / 12$ & -- & 38 & - & 0 & - & 2 & - & 5.0 & - \\
\hline $6 / 14$ & -- & 33 & - & 5 & - & 7 & - & 17.5 & - \\
\hline $6 / 17$ & -- & 33 & - & 0 & - & 7 & - & 17.5 & - \\
\hline $6 / 19$ & -- & 33 & - & 0 & - & 7 & - & 17.5 & - \\
\hline $6 / 22$ & -- & 33 & - & 0 & - & 7 & - & 17.5 & - \\
\hline $6 / 24$ & -- & 32 & - & 1 & - & 8 & - & 20.0 & - \\
\hline $6 / 27$ & -- & 29 & - & 3 & - & 11 & - & 27.5 & - \\
\hline
\end{tabular}

allandling problems due to siltation allowed $36 \mathrm{fish}$ to escape on 3 June. Replicate $A$ was terminated and replicate $B$ was used to plot cunulative percent mortality. 
0

○

○ 
Tahle 12. Results of Instream bloassays using fingerling rainbow trout in the Roulder River downstream of High Ore Creek.

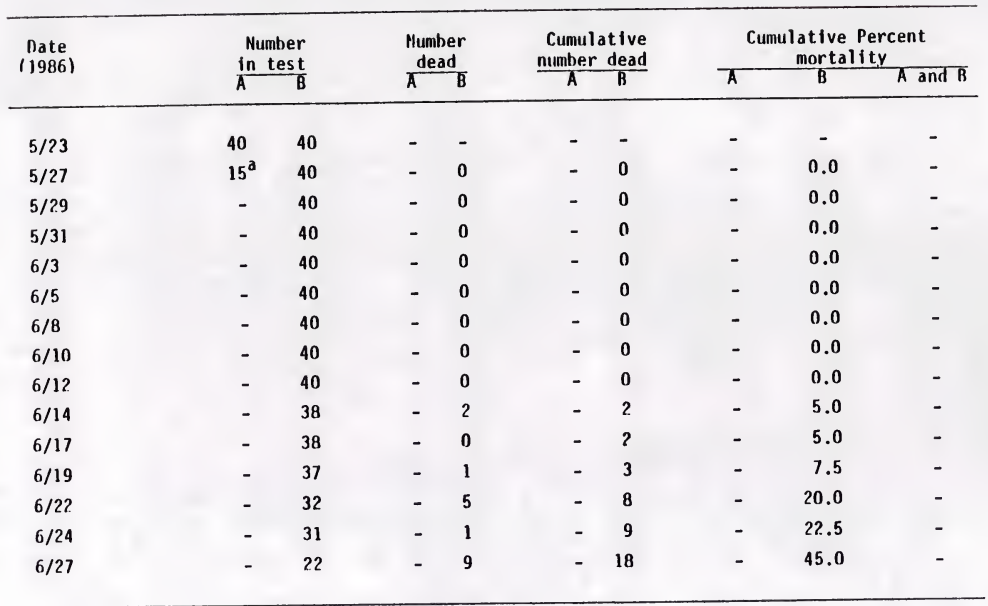

'Handling problems due to siltation allowed $20 \mathrm{fish}$ to escape on 27 May. Replicate A was terminated and Replicate $B$ was used to plot cumulative percent mortality. 
0

0

0 
Basin and the sources of metals pollution but become increasingly less abundant as each metals contaminated tributary enters the mainstem (Nelson 1976).

This work demonstrates that the waters of Basin, High Ore and Cataract Creeks are acutely toxic to rainbow trout and that metals entering the Boulder River from all three tributaries result in a cumulative increase in acute toxicity as you move downstream.

This and previous work (Phillips and Hill 1986) indicate that a large share of the metals in the system originate from tailings deposits and acid mine drainage from: (1) Jack Creek (Basin Creek drainage), (2) Uncle Sam's Gulch and the Crystal Mine (Cataract Creek drainage), and (3) the Comit Mine (High Ore Creek drainage). Future reclamation efforts should focus on these areas.

\section{Clark Fork}

Total alkalinity of the Clark Fork River (Table 13) was lowest near Warm Springs $\left(\bar{x}=72 \mathrm{mg} / 1\right.$ as $\left.\mathrm{CaCO}_{3}\right)$ and highest near Bearmouth $\left(\bar{x}=123 \mathrm{mg} / 1\right.$ as $\left.\mathrm{CaCO}_{3}\right)$. Alkalinity in the mainstem (ignoring the influence of the tributaries), tended to increase from upstream to downstream. However, both the Little Blackfoot River and Rock Creek are less alkaline than the Clark Fork; hence, alkalinity decreases in the mainstem immediately downstream of these tributaries. The trend for hardness was similar -- mean concentrations ranging from 103 (mg/1 as $\mathrm{CaCO}_{3}$ ) at $\mathrm{Cl}$ inton to 177 at Deer Lodge. Racetrack Creek, our control bioassay site, was slightly lower in alkalinity and hardness than the majority of sites. 
-

-

0 
Table 13. Alkalinity, hardness and $\mathrm{pH}$ at five locations in the Clark Fork River and in Silver Bow and Racetrack Creeks.

\begin{tabular}{|c|c|c|c|c|c|c|c|c|c|c|}
\hline \multirow[t]{2}{*}{ Location } & \multirow[t]{2}{*}{$n$} & \multicolumn{3}{|c|}{$\begin{array}{c}\text { Total alkalinity } \\
\text { mg/l as } \mathrm{CaCO}_{3}\end{array}$} & \multicolumn{3}{|c|}{$\begin{array}{c}\text { Mardness } \\
\mathrm{mg} / 1 \text { as } \mathrm{CaCO}_{3}\end{array}$} & \multicolumn{3}{|c|}{$\mathrm{pH}$} \\
\hline & & mean & range & SD & mean & range & SD & mean & range & SD \\
\hline Silverbow Creek & 10 & 84.0 & $64-96$ & \pm 10.2 & 103.8 & $78-122$ & \pm 17.4 & 7.74 & $7.6-8.0$ & \pm 0.13 \\
\hline $\begin{array}{l}\text { Clark Fork River } \\
\text { at Warm Springs }\end{array}$ & 10 & 72.2 & $66-84$ & \pm 11.1 & 127.6 & $80-200$ & \pm 38.7 & 8.15 & $7.9-8.4$ & \pm 0.19 \\
\hline Racetrack Creek & 10 & 83.2 & $28-116$ & \pm 38.7 & 83.0 & $28-116$ & \pm 34.6 & 7.43 & $6.9-7.7$ & $\pm 0,31$ \\
\hline $\begin{array}{l}\mathrm{Cl} \text { ark Fork River } \\
\text { at Deer Lodge }\end{array}$ & 10 & 119.0 & $80-146$ & \pm 23.3 & 176.8 & $96-224$ & \pm 45.0 & 7.77 & $7.4-8.0$ & \pm 0.20 \\
\hline $\begin{array}{l}\text { Clark Fork River } \\
\text { at Gold Creek }\end{array}$ & 10 & 107.6 & $76-128$ & \pm 18.3 & 144.8 & $94-170$ & \pm 28.6 & 7.89 & $7.5-8.1$ & \pm 0.22 \\
\hline $\begin{array}{c}\text { Clark Fork River } \\
\text { at Bearmouth }\end{array}$ & 10 & 122.6 & $96-146$ & \pm 18.3 & 155.2 & $110-184$ & \pm 24.5 & 7.90 & $7.6-8.1$ & \pm 0.19 \\
\hline $\begin{array}{l}\text { Clark Fork River } \\
\text { at Clinton }\end{array}$ & 10 & 92.0 & $62-110$ & \pm 17.9 & 103.2 & $70-124$ & \pm 18.7 & 7.81 & $7.5-8.0$ & \pm 0.20 \\
\hline
\end{tabular}

$\mathrm{KH} / \mathrm{vg}-118 \mathrm{a}-2$ 
○

○

0 
Mean $\mathrm{pH}$ in the mainstem ranged from 7.41 in Racetrack Creek to 8.15 in the Clark Fork at Warm Springs. The $\mathrm{pH}$ averaged 0.2-0.3 units higher at Warm Springs than at downstream sites although alkalinities were greater at Warm Springs. Higher $\mathrm{pH}$ at the upstream site is probably due to biological activity in the Warm Springs Ponds. The fixation of carbon dioxide by green plants during daylight would tend to increase $\mathrm{pH}$. Unfortunately, diurnal $\mathrm{pH}$ fluctuations in the river have not been measured to date. Cessation of photosynthesis by plants during darkness probably causes a considerable decrease in $\mathrm{pH}$ in the river downstream of the ponds.

\section{Metals concentration and loading}

Expectedly, copper and zinc concentrations in Silver Bow Creek were considerably higher than in the Clark Fork River downstream of the Warm Springs Ponds (Figs. 8-9). Copper and zinc concentrations in Silver Bow Creek reached 0.7 and 0.8 $\mathrm{mg} / 1$ respectively and average concentrations were 0.2 and $0.4 \mathrm{mg} / 1$. During the bioassays average copper concentrations $(\mathrm{mg} / 1)$ at mainstem $\mathrm{Clark}$ Fork stations were: Warm Springs - 0.04 , Deer Lodge - 0.05 , Gold Creek - 0.04, Bearmouth 0.04 , and Clinton - 0.02. Average zinc concentrations were: Warm Springs 0.08 , Deer Lodge -0.06 , Gold Creek -0.05 , Bearmouth -0.07 , and Clinton 0.03 . Concentrations of both metals were highest at Warm Springs near mid-May, whereas peak concentrations at downstream sites and in Silver Bow Creek coincided with the peak of runoff in early lune (Figs. 8-10). The reason for the pre-runoff peak at Warm Springs is believed to be a result of heavy winds disturbing the bottom sediments in the Warm Springs Ponds. Water immediately below the ponds was extremely turbid on that sampling date and heavy winds were present. 
-

- 


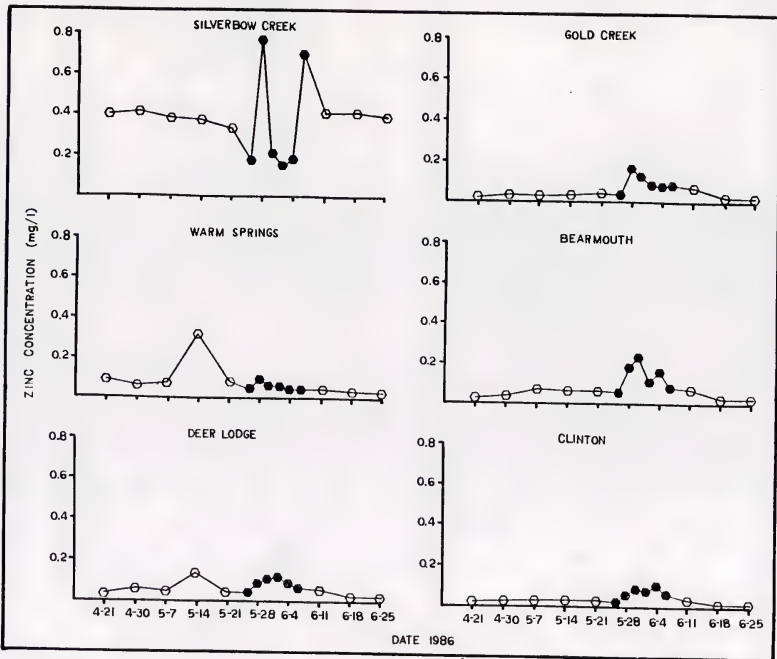

Figure 8. Total recoverable zinc concentrations at bioassay sites in the Clark Fork River drainage. 
-

- 


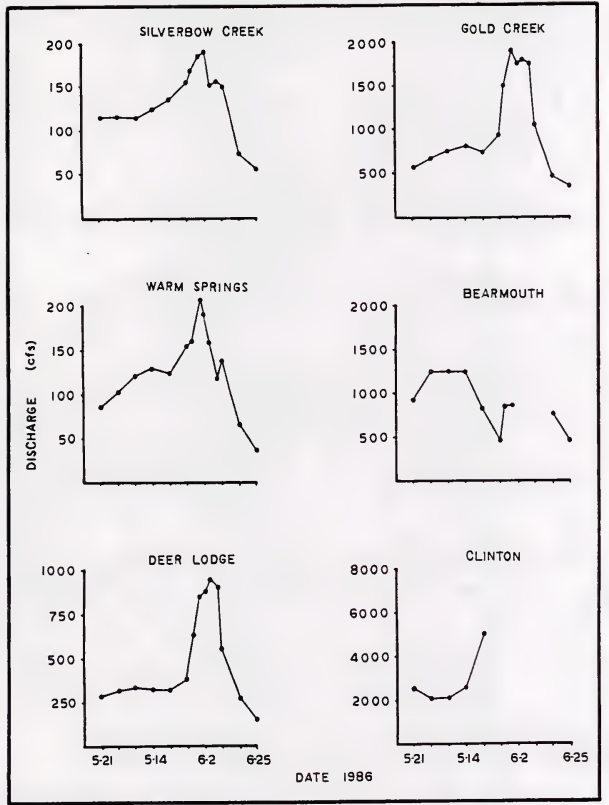

Figure 9. Stream Discharge at several locations in the Clark Fork River drainage. 
-

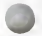

- 


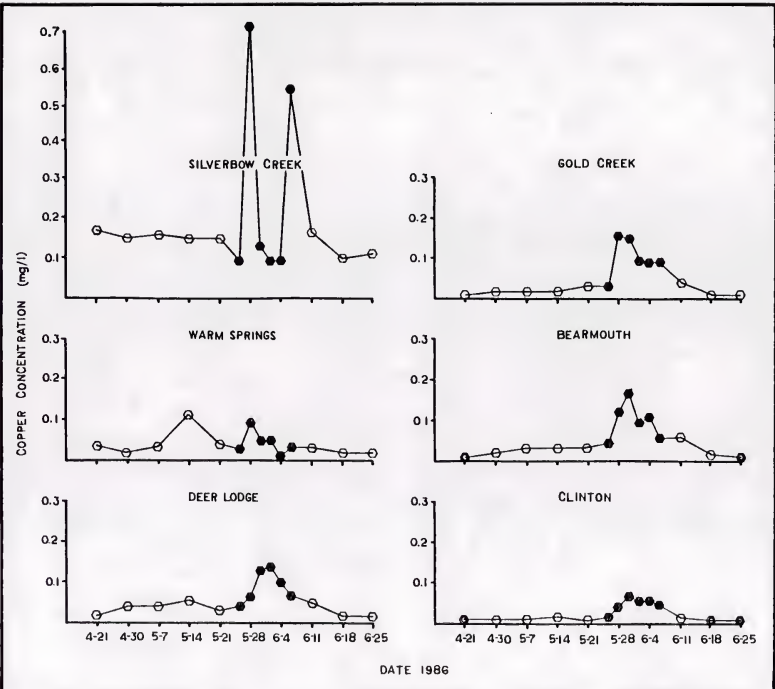

Figure 10. Total recoverable copper concentrations at bioassay sites in the Clark Fork River drainage. 
At a water hardness of $150 \mathrm{mg} / 1$ (as $\mathrm{CaCO}_{3}$ ) the recommended criteria for protection of aquatic life from copper and zinc are approximately 0.015 and 0.050 $\mathrm{mg} / 1$ respectively. The respective percentages of the time the criteria for copper and zinc were exceeded at each station during the bioassays were as follows: Silver Bow Creek 100\%, 100\%; Warm Springs 100\%, 60\%; Deer Lodge 100\%, $60 \%$; Gold Creek $70 \%$, 30\%; Bearmouth $80 \%, 60 \%$; Clinton $40 \%, 20 \%$.

Metals loading was considerably higher in Silver Bow Creek before it enters the Warm Springs Ponds than in the river downstream of the ponds (Tables 14-15). Removal efficiency cannot be determined from our data because the calculations for the site downstream of the ponds also includes contributions from the Mill-Willow bypass. However, the data demonstrate that much of the copper and zinc entering the ponds is removed. In general, loading of both metals continues to increase as you move downstream in the Clark Fork. Phillips (1985) reported similar results in an earlier year and attributed the increase in loading to erosion of the river into tailings deposits located along the banks and to resuspension of riverbed material that contains metals.

\section{Bioassay results}

Rate of mortality was highest in Silver Bow Creek where approximately $89 \%$ of the fish died during the course of the test, and lowest in Racetrack Creek (the control site) where no fish died (Fig. 11 and Tables 16-17). Percentages of mortality at other sites were: Warm Springs - 25\%, Bearmouth - 21\%, Deer Lodge - 15\%, Gold Creek - 7\% and Clinton - 3\% (Fig. 11; Tables 18-22). 
Table 14. Zinc loading at five locations in the $\mathrm{Clark}$ Fork River and in Silver Bow Creek.

Zinc loading $(\mathrm{kg} / \text { day })^{\text {a }}$

\begin{tabular}{|c|c|c|c|c|c|c|c|c|c|c|c|c|c|c|}
\hline \multirow[t]{2}{*}{ Location } & \multicolumn{13}{|c|}{ Date -- 1986} & \multirow[b]{2}{*}{$6 / 25$} \\
\hline & $4 / 21$ & $4 / 30$ & $5 / 7$ & $5 / 14$ & $5 / 21$ & $5 / 26$ & $5 / 28$ & $5 / 30$ & $6 / 2$ & $6 / 4$ & $6 / 6$ & $6 / 11$ & $6 / 18$ & \\
\hline Silverbow Creek & 112.5 & 119.3 & 111.7 & 114.6 & 109.6 & 70.9 & 316.4 & 94.5 & 71.5 & 67.5 & 583.7 & 148.9 & 73.4 & 55.6 \\
\hline $\begin{array}{l}\text { Clark Fork River } \\
\text { at Warm Springs }\end{array}$ & 18.5 & 15.2 & 20.5 & 97.5 & 24.8 & 16.2 & 37.7 & 27.7 & 24.5 & 16.5 & 12.2 & 5.9 & 15.9 & 3.5 \\
\hline $\begin{array}{l}\mathrm{Cl} \text { ark Fork River } \\
\text { at Deer Lodge }\end{array}$ & 25.8 & 43.7 & 43.6 & 100.5 & 35.2 & 43.8 & 114.2 & 230.5 & 257.8 & 207.2 & 150.2 & 74.0 & 16.5 & 12.0 \\
\hline $\begin{array}{l}\text { Clark Fork River } \\
\text { at Cold Creek }\end{array}$ & 26.9 & 63.9 & 58.3 & 78.4 & 79.4 & 88.1 & 597.9 & 594.7 & 350.9 & 310.8 & 303.9 & 154.0 & 31.4 & 24.0 \\
\hline $\begin{array}{l}\mathrm{Clark} \text { Fork River } \\
\text { at Bearmouth }\end{array}$ & 55.9 & 119.0 & 205.7 & 166.4 & 125.7 & 57.6 & 366.1 & 475.6 & $-{ }^{b}$ & $\ldots b$ & $\ldots b$ & 276.8 & 45.8 & 36.1 \\
\hline $\begin{array}{l}\text { Clark Fork River } \\
\text { at } \mathrm{Cl} \text { inton }\end{array}$ & 112.7 & 121.6 & 143.3 & 184.9 & 348.2 & $--^{b}$ & $\ldots b$ & $\ldots b$ & $--^{b}$ & $--^{b}$ & $\ldots b$ & $--^{b}$ & $--^{b}$ & $--^{b}$ \\
\hline
\end{tabular}

${ }^{a}$.d. Denotes sampling dates when copper concentrations were lower than the analytical detection 1 imit of 0.01 mg/l.

b Loading could not be calculated because flows for those dates could not be determined with the existing USCS flow rating tables. We will be able to calculate loading once the USCS constructs new rating tables.

$c_{F l o w}$ readings at the Bearmouth station are instantaneous rather than daily averages; hence, loading calculations at this location have a higher degree of error than those calculated at other stations.

$\mathrm{KH} / \mathrm{vg}-115 \mathrm{a}-1$ 
○

○

- 
Table 15. Copper loading at five locations in the Clark Fork River and in Silver Bow Creek.

Copper loading $(\mathrm{kg} / \text { day })^{\text {a }}$

\begin{tabular}{|c|c|c|c|c|c|c|c|c|c|c|c|c|c|c|}
\hline \multirow[t]{2}{*}{ Location } & \multicolumn{14}{|c|}{ Date -- 1986} \\
\hline & $4 / 21$ & $4 / 30$ & $5 / 7$ & $5 / 14$ & $5 / 21$ & $5 / 26$ & $5 / 28$ & $5 / 30$ & $6 / 2$ & $6 / 4$ & $6 / 6$ & $6 / 11$ & $6 / 18$ & $6 / 25$ \\
\hline Silverbow Creek & 47.8 & 42.9 & 46.2 & 45.9 & 49.5 & 34.1 & 283.5 & 58.8 & 41.8 & 33.0 & 204.7 & 62.4 & 17.9 & 18.1 \\
\hline $\begin{array}{l}\text { Clark Fork River } \\
\text { at Warm Springs }\end{array}$ & 6.3 & 4.9 & 8.8 & 34.8 & 12.1 & 11.3 & 35.3 & 25.7 & 23.6 & n.d. & 8.7 & 10.4 & 3.4 & 1.9 \\
\hline $\begin{array}{c}\text { Clark Fork River } \\
\text { at Deer Lodge }\end{array}$ & 13.6 & 31.2 & 32.3 & 46.4 & 23.5 & 38.0 & 108.0 & 272.4 & 303.3 & 232.8 & 154.6 & 68.4 & 13.7 & 7.5 \\
\hline $\begin{array}{l}\text { Clark Fork River } \\
\text { at Gold Creek }\end{array}$ & 14.1 & 33.6 & 37.6 & 39.2 & 55.4 & 69.6 & 586.9 & 697.0 & 385.1 & 350.2 & 342.4 & 102.7 & 12.1 & 8.3 \\
\hline $\begin{array}{c}\mathrm{Clark} \text { Fork River } \\
\text { at Bearmouth }\end{array}$ & n.d. & 61.0 & 90.8 & 90.8 & 58.9 & 45.2 & 246.9 & 362.5 & $--^{b}$ & $--^{b}$ & $--^{b}$ & 267.9 & 38.2 & n.d. \\
\hline $\begin{array}{l}\text { Clark Fork River } \\
\text { at Clinton }\end{array}$ & n.d. & 50.7 & 53.0 & 123.2 & 120.1 & $--^{b}$ & $--^{b}$ & $--^{b}$ & $--^{b}$ & $--^{b}$ & $--^{b}$ & $--^{b}$ & $--^{b}$ & $-{ }^{b}$ \\
\hline
\end{tabular}

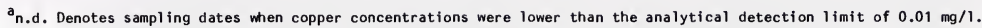

bLoading could not be calculated because flows for those dates could not be determined with the existing uscS flow rating tables. We will be able to calculate loading once the USGS constructs new rating tables.

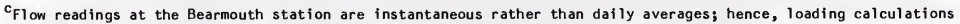
at this location have a higher degree of error than those calculated at other stations.

$\mathrm{KH} / \mathrm{vg}-115 \mathrm{a}-2$ 
-

-

- 


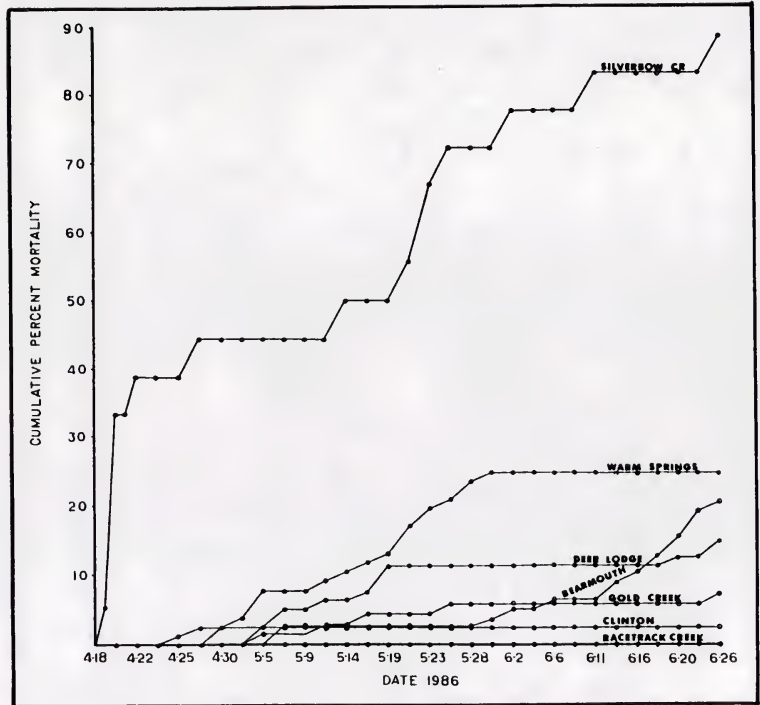

Figure 11. Cumulative percent mortality of fingerling rainbow trout kept at several locations in the Clark Fork River drainage. 
0

0

○ 
Table 16 . Results of instream bioassay using fingerling rainbow trout in Silver Bow
Creek.

\begin{tabular}{|c|c|c|c|c|}
\hline $\begin{array}{l}\text { Date } \\
(1986)\end{array}$ & $\begin{array}{l}\text { Number } \\
\text { in test }\end{array}$ & $\begin{array}{c}\text { Number } \\
\text { dead }\end{array}$ & $\begin{array}{l}\text { Cumulative } \\
\text { mortality }\end{array}$ & $\begin{array}{c}\text { Cumulative percent } \\
\text { mortality }\end{array}$ \\
\hline $\begin{array}{l}4 / 18 \\
4 / 19 \\
4 / 20 \\
4 / 71 \\
4 / 22 \\
4 / 23 \\
4 / 25 \\
4 / 28 \\
4 / 30 \\
5 / 2 \\
5 / 5 \\
5 / 7 \\
5 / 9 \\
5 / 12 \\
5 / 14 \\
5 / 16 \\
5 / 19 \\
5 / 21 \\
5 / 23 \\
5 / 26 \\
5 / 28 \\
5 / 30 \\
6 / 2 \\
6 / 4 \\
6 / 6 \\
6 / 9 \\
6 / 11 \\
6 / 13 \\
6 / 16 \\
6 / 18 \\
6 / 20 \\
6 / 23 \\
6 / 26\end{array}$ & $\begin{array}{l}18 \\
17 \\
12 \\
12 \\
11 \\
11 \\
11 \\
10 \\
10 \\
10 \\
10 \\
10 \\
10 \\
10 \\
9 \\
9 \\
9 \\
8 \\
6 \\
5 \\
5 \\
5 \\
4 \\
4 \\
4 \\
4 \\
3 \\
3 \\
3 \\
3 \\
3 \\
3 \\
2 \\
\end{array}$ & $\begin{array}{l}5 \\
1 \\
5 \\
0 \\
1 \\
0 \\
0 \\
1 \\
0 \\
0 \\
0 \\
0 \\
0 \\
0 \\
1 \\
0 \\
0 \\
1 \\
2 \\
1 \\
0 \\
0 \\
1 \\
0 \\
0 \\
0 \\
1 \\
0 \\
0 \\
0 \\
0 \\
0 \\
1 \\
\end{array}$ & $\begin{array}{r}5 \\
1 \\
6 \\
6 \\
7 \\
7 \\
7 \\
8 \\
8 \\
8 \\
8 \\
8 \\
8 \\
8 \\
9 \\
9 \\
9 \\
10 \\
12 \\
13 \\
13 \\
13 \\
14 \\
14 \\
14 \\
14 \\
15 \\
15 \\
15 \\
15 \\
15 \\
15 \\
16 \\
\end{array}$ & $\begin{array}{r}0 . . \\
53.5 \\
33.3 \\
33.3 \\
38.9 \\
38.9 \\
38.9 \\
44.4 \\
44.4 \\
44.4 \\
44.4 \\
44.4 \\
44.4 \\
44.4 \\
50.0 \\
50.0 \\
50.0 \\
55.6 \\
66.7 \\
72.2 \\
72.2 \\
72.2 \\
77.8 \\
77.8 \\
77.8 \\
77.8 \\
83.3 \\
83.3 \\
83.3 \\
83.3 \\
83.3 \\
83.3 \\
88.9\end{array}$ \\
\hline
\end{tabular}
Replicate treatments were not conducted in Silver Bow Creek because of a shortage of
bioassay fish at the beginning of the test. 
0

0 
Tahle 17. Results of instream bioassay using fingerling rainbow trout in Racetrack Creek near Racetrack.

\begin{tabular}{|c|c|c|c|c|c|c|c|c|c|}
\hline \multirow[t]{2}{*}{$\begin{array}{l}\text { Date } \\
(1986)\end{array}$} & \multicolumn{2}{|c|}{$\begin{array}{l}\text { Number } \\
\text { in test }\end{array}$} & \multicolumn{2}{|c|}{$\begin{array}{c}\text { Number } \\
\text { dead }\end{array}$} & \multicolumn{2}{|c|}{$\begin{array}{l}\text { Cumulative } \\
\text { mortality }\end{array}$} & \multicolumn{3}{|c|}{$\begin{array}{c}\text { Cumulative percent } \\
\text { mortality }\end{array}$} \\
\hline & & 8 & A & $\bar{B}$ & $A$ & 8 & A & B & $A$ and $B$ \\
\hline $4 / 18$ & 39 & 40 & - & - & - & - & - & - & - \\
\hline $4 / 19$ & 39 & 40 & 0 & 0 & 0 & 0 & 0.0 & 0.0 & 0.0 \\
\hline $4 / 20$ & 39 & 40 & 0 & 0 & 0 & 0 & 0.0 & 0.0 & 0.0 \\
\hline $4 / 21$ & 39 & 40 & 0 & 0 & 0 & 0 & 0.0 & 0.0 & 0.0 \\
\hline $4 / 22$ & 39 & 40 & 0 & 0 & 0 & 0 & 0.0 & 0.0 & 0.0 \\
\hline $4 / 23$ & 39 & 40 & 0 & 0 & 0 & 0 & 0.0 & 0.0 & 0.0 \\
\hline $4 / 25$ & 39 & 40 & 0 & 0 & 0 & 0 & 0.0 & 0.0 & 0.0 \\
\hline $4 / 28$ & 39 & 40 & 0 & 0 & 0 & 0 & 0.0 & 0.0 & 0.0 \\
\hline $4 / 30$ & 39 & 40 & 0 & 0 & 0 & 0 & 0.0 & 0.0 & 0.0 \\
\hline $5 / 2$ & 39 & 40 & 0 & 0 & 0 & 0 & 0.0 & 0.0 & 0.0 \\
\hline $5 / 5$ & 39 & 40 & 0 & 0 & 0 & 0 & 0.0 & 0.0 & 0.0 \\
\hline $5 / 7$ & 39 & 40 & 0 & 0 & 0 & 0 & 0.0 & 0.0 & 0.0 \\
\hline $5 / 9$ & 39 & 40 & 0 & 0 & 0 & 0 & 0.0 & 0.0 & 0.0 \\
\hline $5 / 12$ & 39 & 40 & 0 & 0 & 0 & 0 & 0.0 & 0.0 & 0.0 \\
\hline $5 / 14$ & 39 & 40 & 0 & 0 & 0 & 0 & 0.0 & 0.0 & 0.0 \\
\hline $5 / 16$ & 39 & 40 & 0 & 0 & 0 & 0 & 0.0 & 0.0 & 0.0 \\
\hline $5 / 19$ & 39 & 40 & 0 & 0 & 0 & 0 & 0.0 & 0.0 & 0.0 \\
\hline $5 / 21$ & 39 & 40 & 0 & 0 & 0 & 0 & 0.0 & 0.0 & 0.0 \\
\hline $5 / 23$ & 39 & 40 & 0 & 0 & 0 & 0 & 0.0 & 0.0 & 0.0 \\
\hline $5 / 26$ & 39 & 40 & 0 & 0 & 0 & 0 & 0.0 & 0.0 & 0.0 \\
\hline $5 / 28$ & 39 & 40 & 0 & is & 0 & 0 & 0.0 & 0.0 & 0.0 \\
\hline $5 / 30$ & 39 & 40 & 0 & 0 & 0 & 0 & 0.0 & 0.0 & 0.0 \\
\hline $6 / 2$. & 39 & 40 & 0 & 0 & 0 & 0 & 0.0 & 0.0 & 0.0 \\
\hline $6 / 4$ & 39 & 40 & 0 & 0 & 0 & 0 & 0.0 & 0.0 & 0.0 \\
\hline $6 / 6$ & 39 & 40 & 0 & 0 & 0 & 0 & 0.0 & 0.0 & 0.0 \\
\hline $6 / 9$ & 39 & 40 & 0 & 0 & 0 & 0 & 0.0 & 0.0 & 0.0 \\
\hline $6 / 11$ & 39 & 40 & 0 & 0 & 0 & 0 & 0.0 & 0.0 & 0.0 \\
\hline $6 / 13$ & 39 & 40 & 0 & 0 & 0 & 0 & 0.0 & 0.0 & 0.0 \\
\hline $6 / 16$ & 39 & 40 & 0 & 0 & 0 & 0 & 0.0 & 0.0 & 0.0 \\
\hline $6 / 18$ & 39 & 40 & 0 & 0 & 0 & 0 & 0.0 & 0.0 & 0.0 \\
\hline $6 / 20$ & 39 & 40 & 0 & 0 & 0 & 0 & 0.0 & 0.0 & 0.0 \\
\hline $6 / 23$ & 39 & 40 & 0 & 0 & 0 & 0 & 0.0 & 0.0 & 0.0 \\
\hline $6 / 26$ & 39 & 40 & 0 & 0 & 0 & 0 & 0.0 & 0.0 & 0.0 \\
\hline
\end{tabular}

ane fish escaped at some undetermined time during the test. Mortality calculations were based on only 39 fish being present from the beginning. 
0

0

0 
Table 18. Results of instream bioassay using fingerling rainbow trout in the Clark Fork River near Warm Springs.

\begin{tabular}{|c|c|c|c|c|c|c|c|c|c|}
\hline \multirow{2}{*}{$\begin{array}{l}\text { Date } \\
\text { (1986) }\end{array}$} & \multirow{2}{*}{\multicolumn{2}{|c|}{$\begin{array}{l}\text { Number } \\
\text { in test }\end{array}$}} & \multicolumn{2}{|c|}{$\begin{array}{l}\text { Number } \\
\text { dead }\end{array}$} & \multicolumn{2}{|c|}{$\begin{array}{l}\text { Cumulative } \\
\text { mortality }\end{array}$} & \multicolumn{3}{|c|}{$\begin{array}{c}\text { Cumulative percent } \\
\text { mortality }\end{array}$} \\
\hline & & & & $\bar{B}$ & & & A & 8 & $A$ and $B$ \\
\hline $4 / 18$ & 40 & 37 & - & - & - & - & - & - & - \\
\hline $4 / 19$ & 40 & 37 & 0 & 0 & 0 & 0 & 0.0 & 0.0 & 0.0 \\
\hline $4 / 20$ & 40 & 37 & 0 & 0 & 0 & 0 & 0.0 & 0.0 & 0.0 \\
\hline $4 / 21$ & 40 & 37 & 0 & 0 & 0 & 0 & 0.0 & 0.0 & 0.0 \\
\hline $4 / 22$ & 40 & 37 & 0 & 0 & 0 & 0 & 0.0 & 0.0 & 0.0 \\
\hline $4 / 23$ & 40 & 37 & 0 & 0 & 0 & 0 & 0.0 & 0.0 & 0.0 \\
\hline $4 / 25$ & 40 & 37 & 0 & 0 & 0 & 0 & 0.0 & 0.0 & 0.0 \\
\hline $4 / 28$ & 40 & 37 & 0 & 0 & 0 & 0 & 0.0 & 0.0 & 0.0 \\
\hline $4 / 30$ & 38 & 37 & 2 & 0 & 2 & 0 & 5.0 & 0.0 & 2.6 \\
\hline $5 / 2$ & 38 & 36 & 0 & 1 & 2 & 1 & 5.0 & 2.7 & 3.9 \\
\hline $5 / 5$ & 36 & 35 & 2 & $i$ & 4 & 2 & 10.0 & 5.4 & 7.8 \\
\hline $\begin{array}{l}5 / 7 \\
5 / 9\end{array}$ & 36 & 35 & 0 & 0 & 4 & 2 & 10.0 & 5.4 & 7.8 \\
\hline $\begin{array}{l}5 / 9 \\
5 / 12\end{array}$ & $\begin{array}{l}36 \\
35\end{array}$ & $\begin{array}{l}35 \\
35\end{array}$ & 0 & $\begin{array}{l}0 \\
0\end{array}$ & 4 & 2 & 10.0 & 5.4 & 7.8 \\
\hline $5 / 14$ & 34 & 35 & 1 & 0 & $\begin{array}{l}5 \\
6\end{array}$ & $\begin{array}{l}2 \\
2\end{array}$ & $\begin{array}{l}12.5 \\
15.0\end{array}$ & 5.4 & $\begin{array}{r}9.1 \\
10.4\end{array}$ \\
\hline $5 / 16$ & 33 & 35 & $i$ & 0 & 7 & 2 & $\begin{array}{l}17.0 \\
17.5\end{array}$ & $\begin{array}{l}5.4 \\
5.4\end{array}$ & $\begin{array}{l}10.4 \\
11.7\end{array}$ \\
\hline $5 / 19$ & 32 & 35 & 1 & 0 & 8 & 2 & 20.0 & 5.4 & 13.0 \\
\hline $5 / 21$ & 31 & 33 & $i$ & 2 & 9 & 4 & 22.5 & 10.8 & 16.9 \\
\hline $5 / 23$ & 30 & 32 & $i$ & 1 & 10 & 5 & 25.0 & 13.5 & 19.5 \\
\hline $5 / 26$ & 30 & 31 & 0 & $i$ & 10 & 6 & 25.0 & 16.2 & 20.8 \\
\hline $5 / 28$ & 28 & 31 & 2 & 0 & 12 & 6 & 30.0 & 16.2 & 23.4 \\
\hline $\begin{array}{l}5 / 30 \\
6 / 2\end{array}$ & 28 & 30 & 0 & 1 & 12 & 7 & 30.0 & 18.9 & 24.7 \\
\hline $\begin{array}{l}6 / 2 \\
6 / 4\end{array}$ & 28 & 30 & 0 & 0 & 12 & 7 & 30.0 & 18.9 & 24.7 \\
\hline $\begin{array}{l}6 / 4 \\
6 / 6\end{array}$ & 28 & 30 & 0 & 0 & 12 & 7 & 30.0 & 18.9 & 24.7 \\
\hline $\begin{array}{l}6 / 6 \\
6 / 9\end{array}$ & 28 & 30 & 0 & 0 & 12 & 7 & 30.0 & 18.9 & 24.7 \\
\hline $\begin{array}{l}6 / 9 \\
6 / 11\end{array}$ & 28 & 30 & 0 & 0 & 12 & 7 & 30.0 & 18.9 & 24.7 \\
\hline $6 / 11$ & 28 & 30 & 0 & 0 & 12 & 7 & 30.0 & 18.9 & 24.7 \\
\hline $6 / 13$ & 28 & 30 & 0 & 0 & 12 & 7 & 30.0 & 18.9 & 24.7 \\
\hline $6 / 16$ & 28 & 30 & 0 & 0 & 12 & 7 & 30.0 & 18.9 & $? .4 .7$ \\
\hline $6 / 18$ & 28 & 30 & 0 & 0 & 12 & 7 & 30.0 & 18.9 & 24.7 \\
\hline $6 / 20$ & 28 & 30 & 0 & 0 & 12 & 7 & 30.0 & 18.9 & 24.7 \\
\hline $6 / 23$ & 28 & 30 & 0 & 0 & 12 & 7 & 30.0 & 18.9 & 24.7 \\
\hline $6 / 26$ & 28 & 30 & 0 & 0 & 12 & 7 & 30.0 & 18.9 & 24.7 \\
\hline
\end{tabular}

ahree fish escaped at some undetermined time during the test. Mortality calculations were based on only 37 fish being present from the onset. 
a

-

a 
Table 19. Results of instream bloassay using fingerling rainbow trout in the Clark Fork River near Deer Lodae.

\begin{tabular}{|c|c|c|c|c|c|c|c|c|c|}
\hline \multirow[t]{2}{*}{$\begin{array}{l}\text { Date } \\
(1986)\end{array}$} & \multirow{2}{*}{\multicolumn{2}{|c|}{$\begin{array}{l}\text { Number } \\
\text { in test } \\
A \quad B\end{array}$}} & \multicolumn{2}{|c|}{$\begin{array}{l}\text { Number } \\
\text { dead }\end{array}$} & \multicolumn{2}{|c|}{$\begin{array}{l}\text { Cumulative } \\
\text { mortality }\end{array}$} & \multicolumn{3}{|c|}{$\begin{array}{c}\text { Cumulative percent } \\
\text { mortality }\end{array}$} \\
\hline & & & & $\bar{B}$ & $A$ & B & $A$ & 8 & $A$ and $B$ \\
\hline $4 / 18$ & 40 & 40 & - & - & - & - & - & - & - \\
\hline $4 / 19$ & 40 & 40 & 0 & 0 & 0 & 0 & 0.0 & 0.0 & 0.0 \\
\hline $4 / 20$ & 40 & 40 & 0 & 0 & 0 & 0 & 0.0 & 0.0 & 0.0 \\
\hline $4 / 21$ & 40 & 40 & 0 & 0 & 0 & 0 & 0.0 & 0.0 & 0.0 \\
\hline $4 / 22$ & 40 & 40 & 0 & 0 & 0 & 0 & 0.0 & 0.0 & 0.0 \\
\hline $4 / 23$ & 40 & 40 & 0 & 0 & 0 & 0 & 0.0 & 0.0 & 0.0 \\
\hline $4 / 25$ & 40 & 40 & 0 & 0 & 0 & 0 & 0.0 & 0.0 & 0.0 \\
\hline $4 / 28$ & 40 & 40 & 0 & 0 & 0 & 0 & 0.0 & 0.0 & 0.0 \\
\hline $4 / 30$ & 40 & 40 & 0 & 0 & 0 & 0 & 0.0 & 0.0 & 0.0 \\
\hline $5 / ?$. & 40 & 40 & 0 & 0 & 0 & 0 & 0.0 & 0.0 & 0.0 \\
\hline $5 / 5$ & 38 & 40 & 2 & 0 & 2 & 0 & 5.0 & 0.0 & 2.5 \\
\hline $5 / 7$ & 36 & 40 & 2 & 0 & 4 & 0 & 10.0 & 0.0 & 5.0 \\
\hline $5 / 9$ & 36 & 40 & 0 & 0 & 4 & 0 & 10.0 & 0.0 & 5.0 \\
\hline $5 / 12$ & 35 & 40 & 1 & 0 & 5 & 0 & 12.5 & 0.0 & 6.3 \\
\hline $5 / 14$ & 35 & 40 & 0 & 0 & 5 & 0 & 12.5 & 0.0 & 6.3 \\
\hline $5 / 16$ & 34 & 40 & 1 & 0 & 6 & 0 & 15.0 & 0.0 & 7.5 \\
\hline $5 / 19$ & 31 & 40 & 3 & 0 & 9 & 0 & 22.5 & 0.0 & 11.3 \\
\hline $5 / 21$ & 31 & 40 & 0 & 0 & 9 & 0 & 22.5 & 0.0 & 11.3 \\
\hline $5 / 23$ & 31 & 40 & 0 & 0 & 9 & 0 & 22.5 & 0.0 & 11.3 \\
\hline $5 / 26$ & 31 & 40 & 0 & 0 & 9 & 0 & 22.5 & 0.0 & 11.3 \\
\hline $5 / 28$ & 31 & 40 & 0 & 0 & 9 & 0 & 22.5 & 0.0 & 11.3 \\
\hline $5 / 30$ & 31 & 40 & 0 & 0 & 9 & 0 & 27.5 & 0.0 & 11.3 \\
\hline $6 / 2$ & 31 & 40 & 0 & 0 & 9 & 0 & 22.5 & 0.0 & 11.3 \\
\hline $6 / 4$ & 31 & 40 & 0 & 0 & 9 & 0 & 22.5 & 0.0 & 11.3 \\
\hline $6 / 6$ & 31 & 40 & 0 & 0 & 9 & 0 & 22.5 & 0.0 & 11.3 \\
\hline $6 / 9$ & 31 & 40 & 0 & 0 & 9 & 0 & 22.5 & 0.0 & 11.3 \\
\hline $6 / 11$ & 31 & 40 & 0 & 0 & 9 & 0 & 27.5 & 0.0 & 11.3 \\
\hline $6 / 13$ & 31 & 40 & 0 & 0 & 9 & 0 & 22.5 & 0.0 & 11.3 \\
\hline $6 / 16$ & 31 & 40 & 0 & 0 & 9 & 0 & 22.5 & 0.0 & 11.3 \\
\hline $6 / 18$ & 31 & 40 & 0 & 0 & 9 & 0 & 22.5 & 0.0 & 11.3 \\
\hline $6 / 20$ & 30 & 40 & 1 & 0 & 10 & 0 & 25.0 & 0.0 & 12.5 \\
\hline $6 / 23$ & 30 & 40 & 0 & 0 & 10 & 0 & 25.0 & 0.0 & 12.5 \\
\hline $6 / 26$ & 28 & 38 & 2 & 2 & 12 & 2 & 30.0 & 5.0 & 15.0 \\
\hline
\end{tabular}


Table 20. Results of instream bioassay using fingerling rainbow trout in the Clark Fork River near Gold Creek.

\begin{tabular}{|c|c|c|c|c|c|c|c|c|c|}
\hline \multirow{2}{*}{$\begin{array}{c}\text { Oate } \\
(1986)\end{array}$} & \multicolumn{2}{|c|}{$\begin{array}{l}\text { Number } \\
\text { in test: }\end{array}$} & \multicolumn{2}{|c|}{$\begin{array}{c}\text { Number } \\
\text { dead }\end{array}$} & \multicolumn{2}{|c|}{$\begin{array}{l}\text { Cumulative } \\
\text { mortality }\end{array}$} & \multicolumn{3}{|c|}{$\begin{array}{c}\text { Cumulative percent } \\
\text { mortality }\end{array}$} \\
\hline & & & & & & & $\bar{A}$ & $B$ & $A$ and $B$ \\
\hline $4 / 18$ & 40 & 28 & - & - & - & - & - & - & - \\
\hline $4 / 19$ & 40 & 28 & 0 & 0 & 0 & 0 & 0.0 & 0.0 & 0.0 \\
\hline $4 / 20$ & 40 & 28 & 0 & 0 & 0 & 0 & 0.0 & 0.0 & 0.0 \\
\hline $4 / 21$ & 40 & 28 & 0 & 0 & 0 & 0 & 0.0 & 0.0 & 0.0 \\
\hline $4 / 22$ & 40 & 28 & 0 & 0 & 0 & 0 & 0.0 & 0.0 & 0.0 \\
\hline $4 / 23$ & 40 & 28 & 0 & 0 & 0 & 0 & 0.0 & 0.0 & 0.0 \\
\hline $4 / 25$ & 40 & 28 & 0 & 0 & 0 & 0 & 0.0 & 0.0 & 0.0 \\
\hline $4 / 78$ & 40 & 28 & 0 & 0 & 0 & 0 & 0.0 & 0.0 & 0.0 \\
\hline $4 / 30$ & 40 & 28 & 0 & 0 & 0 & 0 & 0.0 & 0.0 & 0.0 \\
\hline $5 / 2$ & 40 & 28 & 0 & 0 & 0 & 0 & 0.0 & 0.0 & 0.0 \\
\hline $5 / 5$ & 39 & 28 & 1 & 0 & 1 & 0 & 2.5 & 0.0 & 1.5 \\
\hline $5 / 7$ & 39 & 28 & 0 & 0 & $i$ & 0 & 2.5 & 0.0 & 1.5 \\
\hline $5 / 9$ & 39 & 28 & 0 & 0 & $i$ & 0 & 2.5 & 0.0 & 1.5 \\
\hline $5 / 12$ & 38 & 28 & 1 & 0 & $?$ & 0 & 5.0 & 0.0 & 2.9 \\
\hline $5 / 14$ & 38 & 28 & 0 & 0 & 2 & 0 & 5.0 & 0.0 & 2.9 \\
\hline $5 / 16$ & 37 & 28 & 1 & 0 & 3 & 0 & 7.5 & 0.0 & 4.4 \\
\hline $5 / 19$ & 37 & 28 & 0 & 0 & 3 & 0 & 7.5 & 0.0 & 4.4 \\
\hline $5 / ? 1$ & 37 & 28 & n & 0 & 3 & 0 & 7.5 & 0.0 & 4.4 \\
\hline $5 / 23$ & 37 & 28 & 0 & 0 & 3 & 0 & 7.5 & 0.0 & 4.4 \\
\hline $5 / 26$ & 36 & 28 & 1 & 0 & 4 & 0 & 10.0 & 0.0 & 5.9 \\
\hline $5 / 28$ & 36 & 28 & 0 & 0 & 4 & 0 & 10.0 & 0.0 & 5.9 \\
\hline $5 / 30$ & 36 & 28 & 0 & 0 & 4 & 0 & 10.0 & 0.0 & 5.9 \\
\hline $6 / 2$ & 36 & 28 & 0 & 0 & 4 & 0 & 10.0 & 0.0 & 5.9 \\
\hline $6 / 4$ & 36 & 28 & 0 & 0 & 4 & 0 & 10.0 & 0.0 & 5.9 \\
\hline $6 / 6$ & 36 & 28 & 0 & 0 & 4 & 0 & 10.0 & 0.0 & 5.9 \\
\hline $6 / 9$ & 36 & 28 & 0 & 0 & 4 & 0 & 10.0 & 0.0 & 5.9 \\
\hline $6 / 11$ & 36 & 28 & 0 & 0 & 4 & 0 & 10.0 & 0.0 & 5.9 \\
\hline $6 / 13$ & 36 & 28 & 0 & 0 & 4 & 0 & 10.0 & 0.0 & 5.9 \\
\hline $6 / 16$ & 36 & 28 & 0 & 0 & 4 & 0 & 10.0 & 0.0 & 5.9 \\
\hline $6 / 18$ & 36 & 28 & 0 & 0 & 4 & 0 & 10.0 & 0.0 & 5.9 \\
\hline $6 / 20$ & 36 & 28 & 0 & 0 & 4 & 0 & 10.0 & 0.0 & 5.9 \\
\hline $6 / 23$ & 36 & 28 & 0 & 0 & 4 & 0 & 10.0 & 0.0 & 5.9 \\
\hline $6 / 26$ & 35 & 28 & 1 & 0 & 5 & 0 & 12.5 & 0.0 & 7.3 \\
\hline
\end{tabular}

awelve fish escaped near the beginning of the test; mortality calculations were based on only 37 fish being present from the onset. 
-

-

○ 
Table 21. Results of instream bloassay using fingerling rainbow trout in the Clark Fork River near Bearmouth.

\begin{tabular}{|c|c|c|c|c|c|c|c|c|c|}
\hline \multirow[t]{2}{*}{$\begin{array}{l}\text { Date } \\
(1986)\end{array}$} & \multirow{2}{*}{\multicolumn{2}{|c|}{$\begin{array}{l}\text { Number } \\
\text { in test } \\
\mathrm{B}\end{array}$}} & \multicolumn{2}{|c|}{$\begin{array}{c}\text { Number } \\
\text { dead }\end{array}$} & \multicolumn{2}{|c|}{$\begin{array}{l}\text { Cumulative } \\
\text { mortality }\end{array}$} & \multicolumn{3}{|c|}{$\begin{array}{c}\text { Cumul ative percent } \\
\text { mortality }\end{array}$} \\
\hline & & & $A$ & $\bar{B}$ & A & & $\bar{A}$ & B & $A$ and $B$ \\
\hline $4 / 18$ & 39 & 39 & - & - & - & - & - & - & - \\
\hline $4 / 19$ & 39 & 39 & 0 & 0 & 0 & 0 & 0.0 & 0.0 & 0.0 \\
\hline $\begin{array}{l}4 / 20 \\
4 / 21\end{array}$ & 39 & 39 & 0 & 0 & 0 & 0 & 0.0 & 0.0 & 0.0 \\
\hline $\begin{array}{l}4 / 22 \\
4 / 23\end{array}$ & $\begin{array}{l}39 \\
39\end{array}$ & $\begin{array}{l}39 \\
39\end{array}$ & $\begin{array}{l}0 \\
0\end{array}$ & $\begin{array}{l}0 \\
0\end{array}$ & 0 & 0 & 0.0 & $\begin{array}{l}0.0 \\
0.0\end{array}$ & $\begin{array}{l}0.0 \\
0.0\end{array}$ \\
\hline $4 / 25$ & 39 & 39 & 0 & 0 & $\begin{array}{l}0 \\
0\end{array}$ & $\begin{array}{l}0 \\
0\end{array}$ & 0.0 & 0.0 & $\begin{array}{l}0.0 \\
0.0\end{array}$ \\
\hline $4 / 28$ & 39 & 39 & 0 & 0 & 0 & 0 & 0.0 & 0.0 & 0.0 \\
\hline $\begin{array}{l}4 / 30 \\
5 / 2\end{array}$ & 39 & 39 & 0 & 0 & 0 & 0 & 0.0 & 0.0 & 0.0 \\
\hline $\begin{array}{l}5 / 2 \\
5 / 5\end{array}$ & 39 & 39 & 0 & 0 & 0 & 0 & 0.0 & 0.0 & 0.0 \\
\hline $\begin{array}{l}5 / 5 \\
5 / 7\end{array}$ & 39 & $\begin{array}{l}39 \\
39\end{array}$ & 0 & 0 & 0 & $\begin{array}{l}0 \\
0\end{array}$ & 0.0 & 0.0 & 0.0 \\
\hline $\begin{array}{l}5 / 7 \\
5 / 9\end{array}$ & 38 & $\begin{array}{l}39 \\
39\end{array}$ & $\begin{array}{l}1 \\
0\end{array}$ & $\begin{array}{l}\mathbf{0} \\
\mathbf{0}\end{array}$ & 1 & $\begin{array}{l}0 \\
0\end{array}$ & $\begin{array}{l}2.6 \\
2.6\end{array}$ & $\begin{array}{l}0.0 \\
0.0\end{array}$ & $\begin{array}{l}1.3 \\
1.3\end{array}$ \\
\hline $\begin{array}{l}5 / 9 \\
5 / 12\end{array}$ & $\begin{array}{l}38 \\
38\end{array}$ & 39 & 0 & 0 & 1 & 0 & 2.6 & 0.0 & 1.3 \\
\hline $5 / 14$ & 38 & 39 & 0 & 0 & 1 & 0 & 2.6 & 0.0 & 1.3 \\
\hline $5 / 16$ & 38 & 39 & 0 & 0 & 1 & 0 & 2.6 & 0.0 & 1.3 \\
\hline $5 / 19$ & 38 & 39 & 0 & 0 & 1 & 0 & 2.6 & 0.0 & 1.3 \\
\hline $\begin{array}{l}5 / 21 \\
5 / 23\end{array}$ & 38 & 39 & 0 & 0 & i & 0 & 2.6 & 0.0 & 1.3 \\
\hline $\begin{array}{l}5 / 26 \\
5 / 28\end{array}$ & $\begin{array}{l}38 \\
38\end{array}$ & $\begin{array}{l}39 \\
39\end{array}$ & $\begin{array}{l}0 \\
0\end{array}$ & $\begin{array}{l}0 \\
0\end{array}$ & $\begin{array}{l}1 \\
1\end{array}$ & $\begin{array}{l}0 \\
0\end{array}$ & $\begin{array}{l}2.6 \\
2.6\end{array}$ & $\begin{array}{l}0.0 \\
0.0\end{array}$ & 1.3 \\
\hline $\begin{array}{l}5 / 30 \\
6 / 2\end{array}$ & 38 & 36 & 0 & 1 & i & 3 & 2.6 & 7.7 & 5.1 \\
\hline $6 / 4$ & 38 & 36 & 0 & 0 & 1 & 3 & 2.6 & 7.7 & 5.1 \\
\hline $6 / 6$ & 38 & 35 & 0 & 1 & 1 & 4 & 2.6 & 10.3 & 6.4 \\
\hline $6 / 9$ & 38 & 35 & 0 & 0 & 1 & 4 & 2.6 & 10.3 & 6.4 \\
\hline $6 / 11$ & 38 & 35 & 0 & 0 & 1 & 4 & 2.6 & 10.3 & 6.4 \\
\hline $6 / 13$ & 36 & 35 & 2 & 0 & 3 & 4 & 7.7 & 10.3 & 9.0 \\
\hline $6 / 16$ & 35 & 35 & 1 & 0 & 4 & 4 & 10.3 & 10.3 & 10.3 \\
\hline $6 / 18$ & 33 & 35 & 2 & 0 & 6 & 4 & 15.4 & 10.3 & 12.8 \\
\hline $6 / 20$ & 31 & 35 & 2 & 0 & 8 & 4 & 20.5 & 10.3 & 15.3 \\
\hline $6 / 23$ & 28 & 35 & 3 & 0 & 11 & 4 & 28.2 & 10.3 & 19.2 \\
\hline $6 / 26$ & 28 & 34 & 0 & 1 & 11 & 5 & 28.2 & 12.8 & 20.5 \\
\hline
\end{tabular}

ane fish escaped from each treatment at ome undetermined time during the test. Mortality calculations were based on 39 fish being present in each treatment from the onset. 
-

.

- 
Table 22 Results of instream bioassay using fingerling rainbow trout in the Clark Fork River
near Clinton.

\begin{tabular}{|c|c|c|c|c|c|c|c|c|c|}
\hline \multirow[t]{2}{*}{$\begin{array}{l}\text { Date } \\
(1986)\end{array}$} & \multirow{2}{*}{\multicolumn{2}{|c|}{$\begin{array}{l}\begin{array}{c}\text { Number } \\
\text { in test }\end{array} \\
\frac{B}{8}\end{array}$}} & \multirow{2}{*}{\multicolumn{2}{|c|}{$\begin{array}{c}\text { Number } \\
\text { dead } \\
A \quad B\end{array}$}} & \multirow{2}{*}{\multicolumn{2}{|c|}{$\begin{array}{l}\text { Cumulative } \\
\text { mortality } \\
A \quad B\end{array}$}} & \multicolumn{3}{|c|}{$\begin{array}{c}\text { Cumulative percent } \\
\text { mortality }\end{array}$} \\
\hline & & & & & & & A & $B$ & $A$ and $B$ \\
\hline $4 / 18$ & 40 & 40 & - & - & - & - & - & - & - \\
\hline $4 / 19$ & 40 & 40 & 0 & 0 & $\overline{0}$ & $\overline{0}$ & 0.0 & 0.0 & 0.0 \\
\hline $4 / 20$ & 40 & 40 & 0 & 0 & 0 & 0 & 0.0 & 0.0 & 0.0 \\
\hline $4 / 21$ & 40 & 40 & 0 & 0 & 0 & 0 & 0.0 & 0.0 & 0.0 \\
\hline $4 / 72$ & 40 & 40 & 0 & 0 & 0 & 0 & 0.0 & 0.0 & 0.0 \\
\hline $4 / 23$ & 40 & 40 & 0 & 0 & 0 & 0 & 0.0 & 0.0 & 0.0 \\
\hline $4 / 25$ & 40 & 39 & 0 & 1 & 0 & 1 & 0.0 & 2.5 & $\begin{array}{l}0.0 \\
1.2\end{array}$ \\
\hline $4 / 28$ & 40 & 38 & 0 & 1 & 0 & 2 & 0.0 & 5.0 & 2.5 \\
\hline $4 / 30$ & 40 & 38 & 0 & 0 & 0 & 2 & 0.0 & 5.0 & 2.5 \\
\hline $5 / 2$ & 40 & 38 & 0 & 0 & 0 & 2 & 0.0 & 5.0 & 2.5 \\
\hline $5 / 5$ & 40 & 38 & 0 & 0 & 0 & 2 & 0.0 & 5.0 & 2.5 \\
\hline $5 / 7$ & 40 & 38 & 0 & 0 & 0 & $?$ & 0.0 & 5.0 & 2.5 \\
\hline $5 / 9$ & 40 & 38 & 0 & 0 & 0 & 2 & 0.0 & 5.0 & 2.5 \\
\hline $5 / 12$ & 40 & 38 & 0 & 0 & 0 & 2 & 0.0 & 5.0 & 2.5 \\
\hline $5 / 14$ & 40 & 38 & 0 & 0 & 0 & 2 & 0.0 & 5.0 & 2.5 \\
\hline $5 / 16$ & 40 & 38 & 0 & 0 & 0 & 2 & 0.0 & 5.0 & 2.5 \\
\hline $5 / 19$ & 40 & 38 & 0 & 0 & 0 & 2 & 0.0 & 5.0 & 2.5 \\
\hline $\begin{array}{l}5 / 21 \\
5 / 23\end{array}$ & & 38 & 0 & 0 & 0 & 2 & 0.0 & 5.0 & 2.5 \\
\hline $5 / ? 3$ & $\begin{array}{l}40 \\
40\end{array}$ & 38 & 0 & 0 & 0 & 2 & 0.0 & 5.0 & 2.5 \\
\hline $\begin{array}{l}5 / 26 \\
5 / 28\end{array}$ & & 38 & 0 & 0 & 0 & 2 & 0.0 & 5.0 & 2.5 \\
\hline $\begin{array}{l}5 / 28 \\
5 / 30\end{array}$ & $\begin{array}{l}40 \\
40\end{array}$ & & 0 & 0 & 0 & 2 & 0.0 & 5.0 & 2.5 \\
\hline $6 / ?$ & 40 & $\begin{array}{l}38 \\
38\end{array}$ & $\begin{array}{l}0 \\
0\end{array}$ & $\begin{array}{l}0 \\
0\end{array}$ & 0 & 2 & 0.0 & 5.0 & 2.5 \\
\hline $6 / 4$ & 40 & 38 & 0 & $\begin{array}{l}0 \\
0\end{array}$ & $\begin{array}{l}0 \\
0\end{array}$ & 2 & 0.0 & 5.0 & 2.5 \\
\hline $6 / 6$ & 40 & 38 & 0 & 0 & 0 & 2 & $\begin{array}{l}0.0 \\
0.0\end{array}$ & 5.0 & 3.5 \\
\hline $6 / 9$ & 40 & 38 & 0 & 0 & 0 & 2 & & 5.0 & 2.5 \\
\hline $6 / 11$ & 40 & 38 & 0 & 0 & 0 & 2 & 0.0 & 5.0 & 2.5 \\
\hline $6 / 13$ & 40 & $38^{\mathrm{a}}$ & 0 & 0 & 0 & 2 & 0.0 & $\begin{array}{l}5.0 \\
5.0\end{array}$ & $\begin{array}{l}2.5 \\
2.5\end{array}$ \\
\hline $6 / 16$ & 40 & - & 0 & $=$ & 0 & 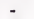 & 0.0 & $\because 0$ & 2.5 \\
\hline $6 / 18$ & 40 & - & 0 & - & 0 & - & 0.0 & - & 2.5 \\
\hline $6 / 20$ & 40 & - & 0 & - & 0 & - & 0.0 & - & 2.5 \\
\hline $6 / 23$ & 40 & - & 0 & - & 0 & - & 0.0 & - & 2.5 \\
\hline $6 / 26$ & 40 & - & 0 & - & 0 & - & 0.0 & - & 2.5 \\
\hline
\end{tabular}

'One of the holding chambers (replicate B) disappeared on June 16. After this date would have 
-

0 
The high rate of mortality at Warm Springs was surprising because this reach of river supports the highest fish populations. Nevertheless, during the tests metals concentrations were higher at this site than at other mainstem sites. Our bioassay site was a few hundred meters upstream of the confluence with Warm Springs Creek -- a high quality tributary that provides a refuge from high metals concentrations. Perhaps fish in this reach are able to avoid toxicity by seeking the plume from Warm Springs Creek. Metals in this reach of the river may also be sequestered by high densities of suspended algae that enter the river from the Warm Springs Ponds. Further, data is necessary to understand the reasons why resident fish in this reach are protected from metals toxicity.

Mortality patterns of bioassay fish in the remaining mainstem reaches appeared to coincide with density patterns of native fish in the river. Lowest mortality rates occurred at Gold Creek and $\mathrm{Clinton}$ which are located downstream of the confluences with the Little Blackfoot River and Rock Creek -- sections that support several hundred trout per mile (Workman 1985), whereas higher cumulative rates of mortality were observed near Deer Lodge (15\%) and Bearmouth (21\%) -reaches that support low trout densities (Workman 1985).

Additional bioassays are planned during May and June of 1987 using feed-up stage rainbow trout -- a more sensitive life stage than fingerlings. Hopefully, these tests will increase our understanding of the influence of metals on the distribution and abundance of fish in the river. 
○

○ 


\section{STREAMFLOW AND DIURNAL DISSOLVED OXYGEN TRENDS IN UPPER MISSOURI RIVER DRAINAGE STREAMS}

Lowered streamflows reduce the rate of exchange of water and increase the chances that biological processes will deplete the oxygen content of the stream. Oxygen depletion is most likely to occur overnight when plants are unable to replenish oxygen by photosynthesizing. Lowered streamflow may also increase water temperature in the stream thereby reducing the oxygen carrying capacity of the water.

To try and document the effect of reduced streamflow on dissolved oxygen in the Missouri River system, we monitored overnight changes in dissolved oxygen concentration during the severe low water year of 1985 . Information was gathered to support our instream flow reservation request in the Missouri River drainage.

\section{Methods}

Measurements were made in seven major tributaries on two dates each to provide comparative information at differing streamflows. Locations and dates included the Ruby River near Sheridan on July 11-12 and September 9-10, The Beaverhead River near Twin Bridges on June 20-21 and September 25-26, The Big Hole River near Twin Bridges on June 20-21 and September 11-12, the Jefferson River near Twin Bridges on June 12-13 and August 28-29, the East Gallatin River near Bozeman on July 16-17 and September 19-20, the West Gallatin River near Logan on July 11-12 and September 17-18, and Little Prickly Pear Creek near its mouth on July 8-9 and August 26-27. 
Dissolved oxygen measurements were taken at two hour intervals beginning at 6:00 P.M. and ending at 10:00 A.M. the following day. Measurements were made using the azide modification of the standard Winkler method (APHA 1976). Water temperature was also recorded at the time of each measurement and percentage of saturation was calculated.

Streamflows in the Beaverhead, Ruby, Jefferson, and Big Hole Rivers were determined from USGS records; streamflow records were not available for the East Gallatin River and Little Prickly Pear Creek.

\section{Results}

At all locations except the Ruby River, Dissolved oxygen concentrations were lower during the low flow period than during the high (Figs. 12-18). In the Ruby, stream discharges during the two periods of measurement were similar -averaging $288 \mathrm{cfs}$ in July and $206 \mathrm{cfs}$ in September. Percentage saturation of dissolved oxygen also reached lower levels during the low flow period than during the high at most locations (Figs. 12-18) al though the variation was not as great as for concentration because the high flow measurements were usually taken later in the summer when water temperatures were higher. Higher streamflows late in the summer were due to rainfall.

The most severe depletion of dissolved oxygen occurred in the East Gallatin River, where during low, flow the concentration dropped to $3.3 \mathrm{mg} / 1$ and percentage saturation to near $40 \%$. Lowest oxygen concentrations $(\mathrm{mg} / 1)$ recorded at other locations were: Beaverhead River - 5.4, Jefferson River - 5.9, Ruby 
○

0

0 


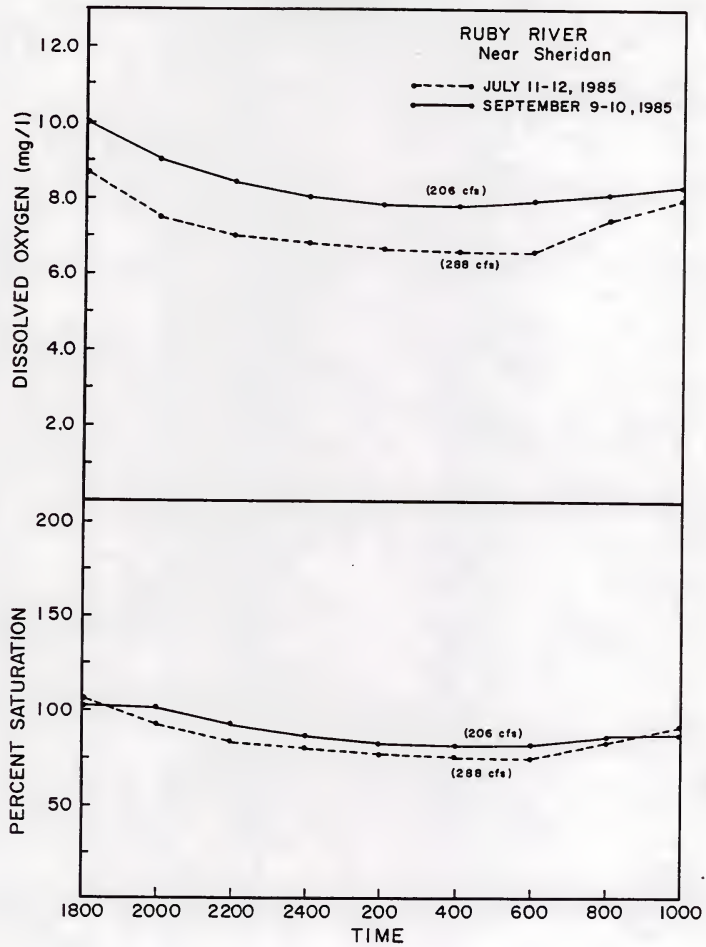

Figure 12. Diurnal changes in dissolved oxygen concentration and percentage saturation of dissolved oxygen at differing streamflows in the Ruby River. 
-

- 


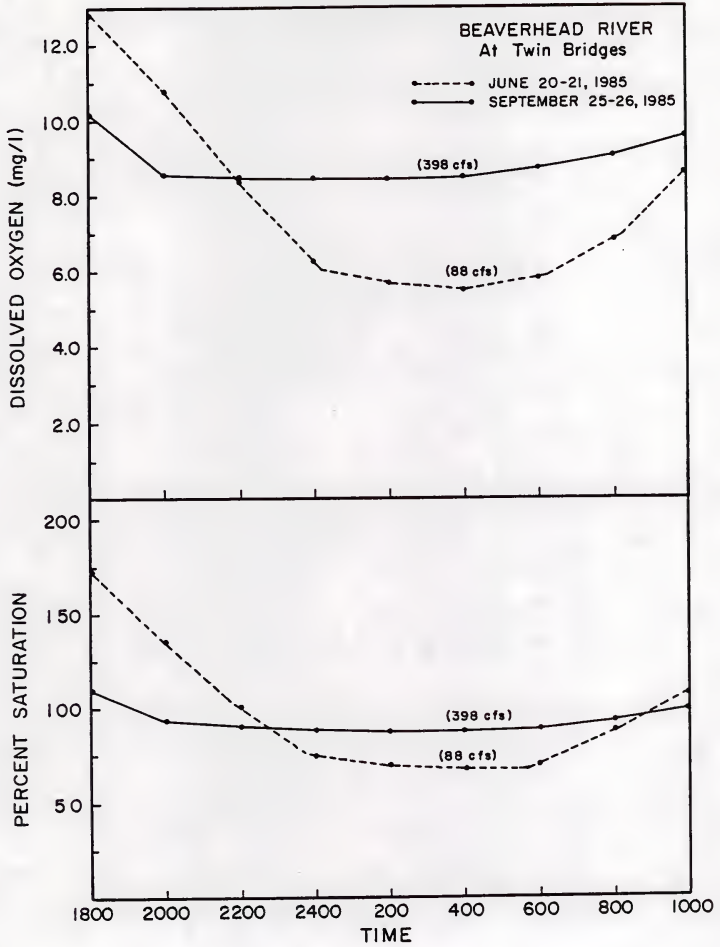

Figure 13. Diurnal changes in dossolved oxygen concentration and percentage saturation of dissolved oxygen at differing streamflows in the Beaverhead River. 
-

-

- 


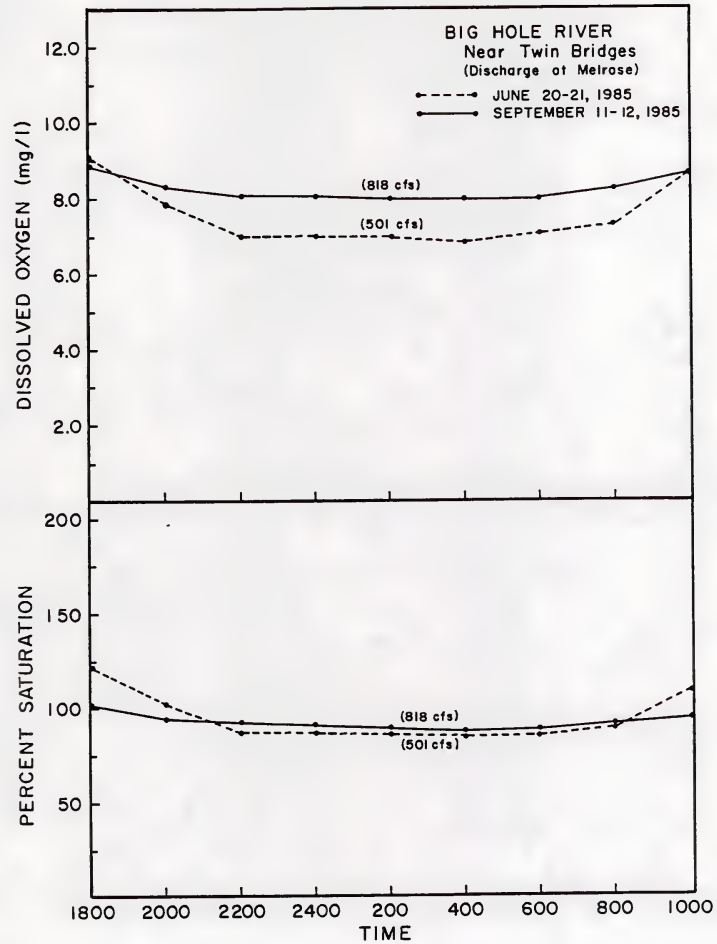

Figure 14. Diurnal changes in dissolved oxygen concentration and percentage saturation of dissolved oxygen at differing streamflows in the Big Hole River. 
○

0

○ 


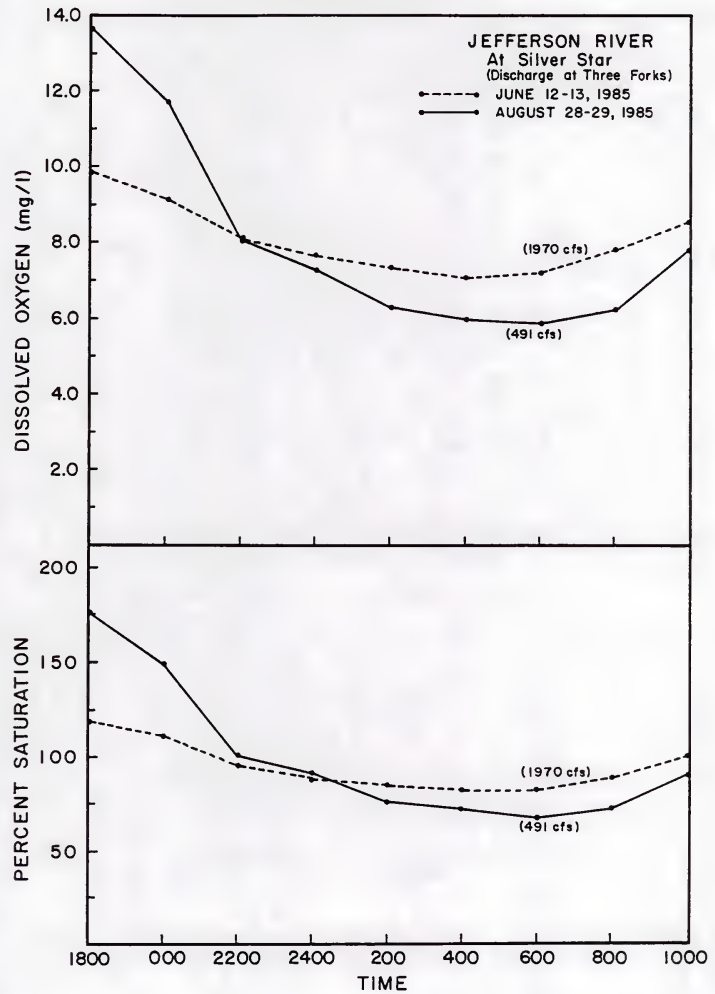

Figure 15. Diurnal changes in dissolved oxygen concentration and percentage saturation of dissolved oxygen at differing streamflows in the Jefferson River. 
○

0 


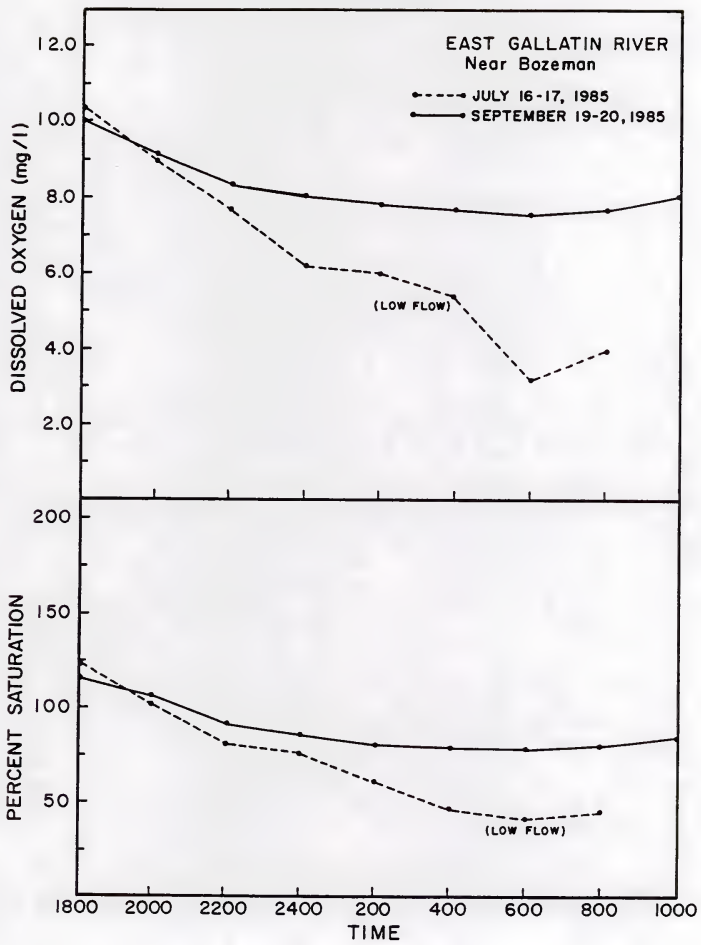

Figure 16. Diurnal changes in dissolved oxygen concentration and percentage saturation of dissolved oxygen at differing streamflows in the East Gallatin River. 
.

0

0 


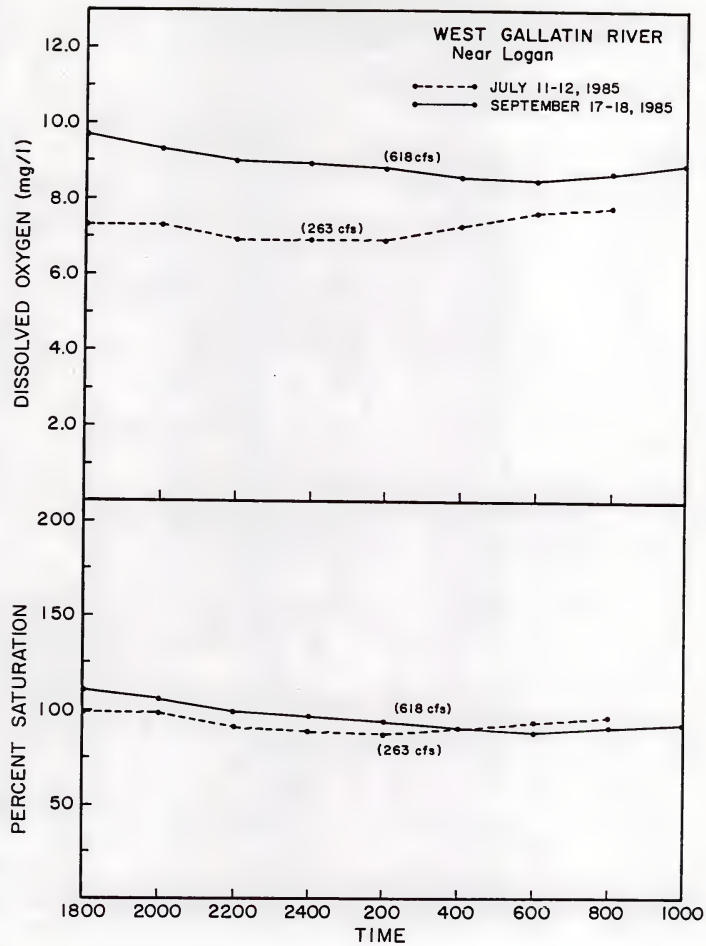

Figure 17. Diurnal changes in dissolved oxygen concentration and percentage saturation of dissolved oxygen at differing streamflows in the West Gallatin River. 


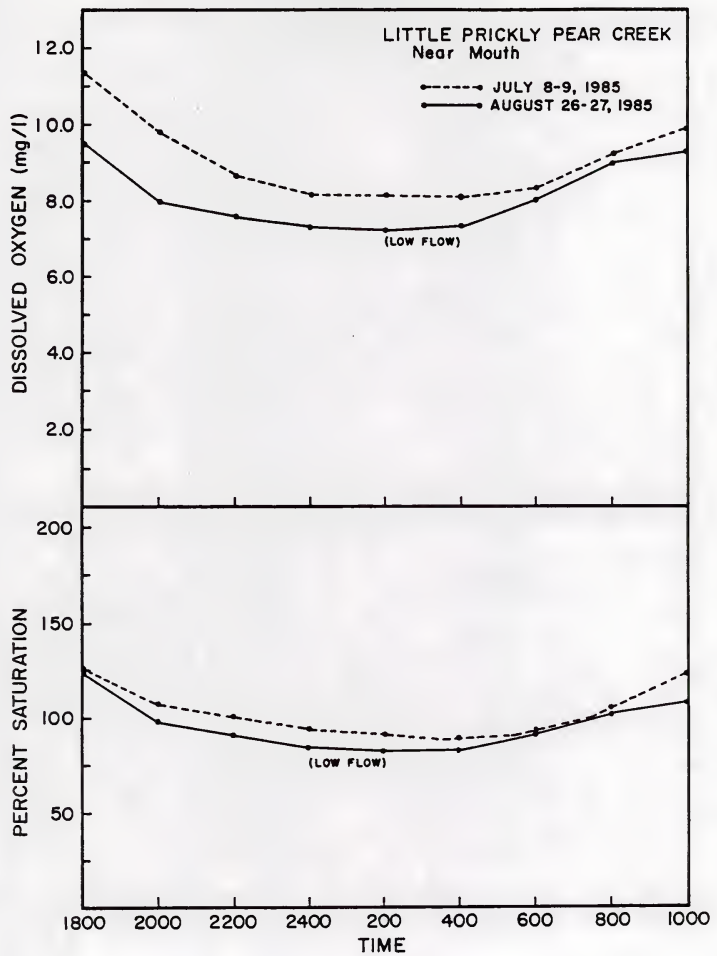

Figure 18. Diurnal changes in dissolved oxygen concentration and percentage saturation of dissolved oxygen at differing streamflows in Little Prickley Pear Creek. 
River - 6.6, Big Hole River - 6.8 , West Gallatin River - 6.8 , and Little Prickley Pear Creek - 7.3.

The largest diurnal swing in dissolved oxygen concentration during the low flow measurement occurred in the Jefferson River where concentration dropped from 13.7 to $5.9 \mathrm{mg} / 1$-- a drop of $7.8 \mathrm{mg} / 1$. The swing $(\mathrm{mg} / 1)$ at other locations were: East Gallatin - 7.1 (10.4 to 3.3), Beaverhead - 7.0 (12.7 to 5.7), Little Prickley Pear -2.3 (9.5 to 7.2 ), Ruby -2.3 (10 to 7.7 ), Big Hole -2.1 (9.0 to 6.9), and West Gallatin - $0.9(7.7$ to 6.8$)$.

Holeton (1971) showed that rainbow trout experience bradycardia (lowered heart rate) below about $7.0 \mathrm{mg} \mathrm{O}_{2} / 1$ and Davis (1975) observed that blood of sockeye salmon is not fully saturated with oxygen below $6.7 \mathrm{mg} 0_{2} / 1$. Davis et al. (1963) determined that any reduction in dissolved oxygen below $100 \%$ saturation resulted in a decline in swimming speed of juvenile chinook salmon. Davis (1975) recommends that dissolved oxygen concentrations should remain above 8.0 $\mathrm{mg} / 1$ to protect early life stages of salmonids but notes, as indicated above, that subtle signs of distress will occur at even higher concentrations.

All of the streams that we monitored experienced oxygen concentrations that would be stressful to salmonids. The situation was particularly severe in the East Gallatin River where concentrations were in a range that was lethal to early life stages of salmonids during laboratory experiments (Alderdice et al. 1958). Our data support the need to maintain streamflows in the Missouri River drainage to sustain the salmonid fishery. 
SEASONAL AND DIURNAL CHANGES IN THE WATER CHEMISTRY OF HAMBY LAKE, BEAVERHEAD MOUNTAINS

Acid deposition is the term used to describe the variety of means by $w^{2}: ?$ atmospheric acids reach the surface of the earth. Gaseous sulfur diox $\rightarrow \vec{r}$ and nitrogen oxides originating principally from the combustion of fossil $\&$ is and from the metals smelting industry undergo complicated changes in the a sphere to form sulfuric and nitric acids. Atmospheric acids may fall as rair "." snow or even as dry material -- hence the term deposition.

Most of the concern over acid deposition in North America has focused a areas downwind of major industrial centers in the eastern United States. Honerer, there is increasing evidence that acid deposition is occurring in the neit including in Montana. Snow surveys conducted by the Soil Conservation show that snow falling in southwestern Montana commonly has a pH betwe 4.0 and 5.0 (SCS 1981; SCS 1982; SCS 1983). Snow or rainfall having a pH of ist than 5.6 is suspected of being acidified by man-caused activities (rainwater in equilibrium with natural atmospheric gases, such as $\mathrm{CO}_{2}$, has a $\mathrm{pH}$ of ainil 5.6). However, methods for tracing the sources of atmospheric acids have not irached the level of sophistication necessary to identify with certainty where Mintana's acid deposition originates.

Both the Environmental Protection Agency (EPA) and the Montana Departnill. of Fish, Wildlife and Parks (MDFWP) have conducted surveys of the chemistiv of alpine lakes in Montana. The MDFWP has obtained information on 62 lakn including 20 in the Spanish Peaks, 15 in the Beaverhead Mountains, 9 in the Writ Pioneer Mountains, and 18 in the East Pioneer Mountains. The EPA has surveyed an additional 80 lakes throughout the western half of the state. 
-

- 
These surveys typically involve only one visit to the lake during the ice-free season of the year (usually between July and September). The time of day that a given lake is sampled may also vary but is usually restricted to daylight hours.

We were concerned that physical and biological processes which vary diurnally and seasonally (and that are capable of altering lake chemistry) add an element of variability that is not being taken into consideration. Accordingly, we conducted water chemistry surveys during different seasons and times of day in Hamby Lake in the Beaverhead Mountains to evaluate diurnal and seasonal trends.

\section{Methods}

Hamby Lake was visited during different months in three successive years including July 1-2, 1986; August 14-15, 1985; and September 19-20, 1984. During each sampling trip the lake was sampled at 4-h intervals beginning at about 3:00 p.m. and ending near noon the following day. At each sampling time, water was collected from the surface of the lake, near the bottom, and from one or two midwater locations. All samples were taken from the same surface location which was marked with an anchored float.

Parameters that were measured included water temperature, total alkalinity (as $\left.\mathrm{CaCO}_{3}\right), \mathrm{pH}$, and dissolved oxygen concentration. Temperature was measured with a standard mercury thermometer, dissolved oxygen by titration using the azide modification of the Winkler method, alkalinity by titration with sulfuric acid using bromo cresol green-methyl red indicator solution, and pH with a Corning Model $620 \mathrm{pH}$ meter equipped with a special probe for low ionic strength solutions. 
-

0

○ 
Expectedly, Hamby Lake waters warmed during the day and cooled overnight. Water temperatures at the surface of the lake were slightly warmer in July and August than in September (Figs. 17-19). Temperature was uniform in the water column in August but varied from surface to bottom in July and September. Stratification was a diurnal phenomenon with surface water temperatures approaching those of bottom waters during the night but warming during the day by as much as $8^{\circ} \mathrm{C}$.

Dissolved oxygen remained relatively high throughout the water column during all months of sampling (Figs. 19-21). The highest concentration recorded was 10 $\mathrm{mg} / \mathrm{l}$ in July and the lowest was about $7 \mathrm{mg} / 1$ during September. Dissolved oxygen was lower at the surface than at the bottom in July probably because surface water temperatures were warmer. Dissolved oxygen concentrations during August were uniform throughout the lake but in September a slight oxygen deficit was evident near the bottom; bottom waters averaged about $1 \mathrm{mg} / 1$ less oxygen than surface or midwater depths. Absence of a large oxygen deficit is typical of low productivity alpine lakes.

The $\mathrm{pH}$ was the most variable parameter measured (Figs. 19-21). Values were significantly lower in July (when the diurnal range was from 5.4-6.2) than in August or September when the $\mathrm{pH}$ was always greater than 7.1. Others have reported that $\mathrm{pH}$ of lakes in areas receiving acid deposition is lowest in the spring shortly after the ice goes off (Jeffries et a1. 1979). This has been attributed to acid entering the lake during the early stages of snowmelt. Ice off and early snowmelt at a high elevation lake such as Hamby Lake (elevation $8,092 \mathrm{ft}$.) probably occurs in late May or early June. The lower $\mathrm{pH}$ 's that we 
.

0

 


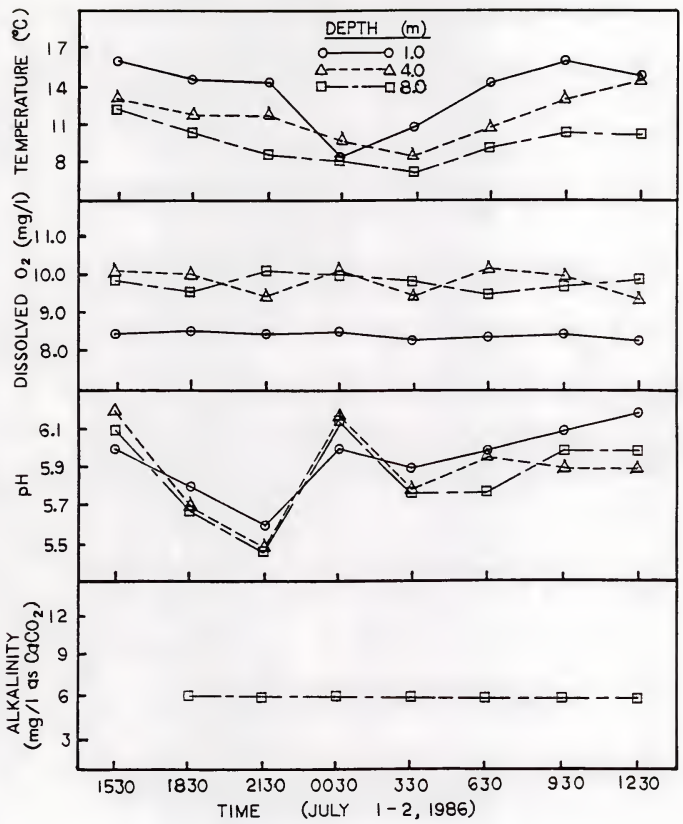

Figure 19. Diurnal trends at several depths in Hamby Lake for total alkalinity, $\mathrm{pH}$, dissolved oxygen concentration, and water temperature (July 1-2, 1986). 
-

-

- 


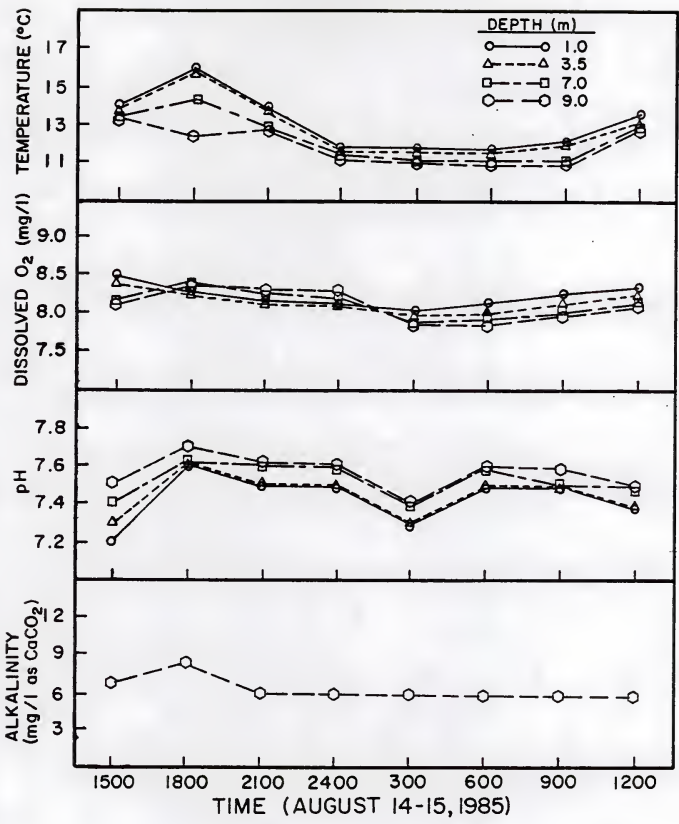

Figure 20. Diurnal trends at several depths in Hamby Lake for total alkalinity, $\mathrm{pH}$, dissolved oxygen concentration, and water temperature (August 24-15, 1985). 
-

○

0 


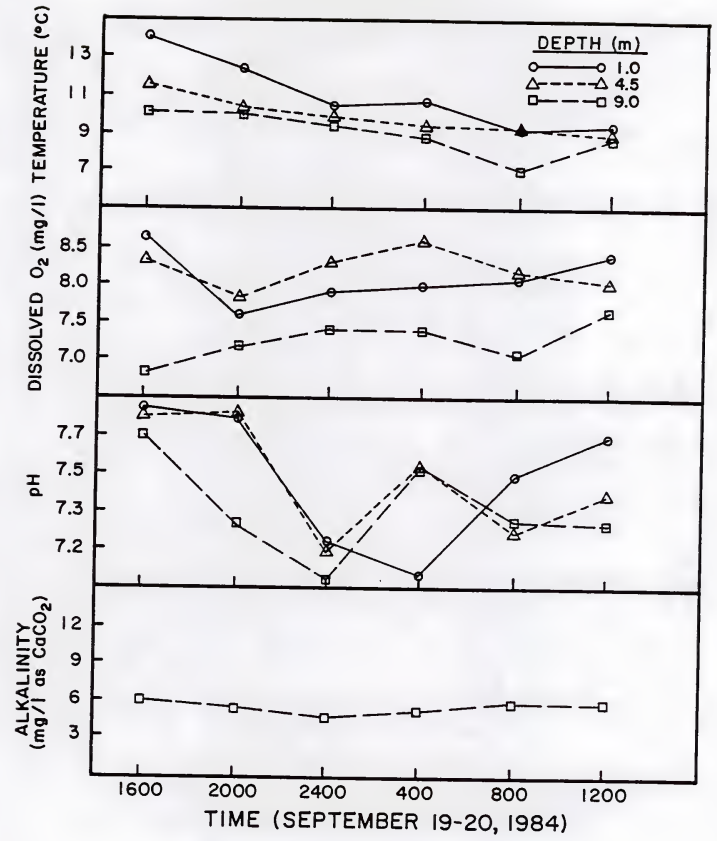

Figure 21. Diurnal trends at several depths in Hamby Lake for total alkalinity, $\mathrm{pH}$, dissolved oxygen concentration, and water temperature (September 19-20, 1984). 
-

○

0 
observed in early July may be due to snowmelt. The pH values that occur in July are in a range that has been shown to reduce the hatchability of brook trout eggs (Menendez 1976). Fortunately, brook trout are fall spawners. The pH's that we measured in September should not impair brook trout reproduction.

Total alkalinity was the most stable parameter that we measured (Figs. 17-19) remaining near $6 \mathrm{mg} / 1$ (as $\mathrm{CaCO}_{3}$ ) regardless of the time of day or season of measurement. Alkalinity may be the best parameter for evaluating long-term changes in lake chemistry and subsequent susceptibility to acid deposition. Other parameters, particularly pH, vary considerably both diurnally and seasonally. The occurrence of these fluctuations needs to be accounted for when interpreting lake $\mathrm{pH}$ measurements. 
-

- 
The acidification of lakes is a slow process and requires many years, perhaps decades, to document whether change has occurred. In Montana we have only begun to collect the baseline information that will be required to gauge future changes in lake acidity that may be experienced. We previously collected baseline water chemistry information on 42 lakes including lakes located in the Beaverhead, East Pioneer, and West Pioneer Mountains. This report describes information on an additional 20 lakes in the Spanish Peaks Wilderness.

Not all natural waters are equally sensitive to acids -- for example alkaline waters are virtually immune to acid deposition. Lakes that overly geologic materials that are deficient in limestone, such as granite, do not have the inate ability to buffer acids. Consequently our monitoring efforts have been concentrated in granitic alpine basins.

\section{Methods}

A11 lakes were sampled during July or August of 1985. Samples were taken from the surface of the lake by personnel from the Gallatin National Forest. Samples were refrigerated as soon as possible and analyzed within 30 days for specific conductivity, pH, calcium, magnesium, sodium, potassium, bicarbonate, chloride, sulfate and total alkalinity. Analyses were performed by the Chemistry Laboratory Bureau of the Montana Department of Health and Environmental Sciences using procedures approved by the Environmental Protection Agency (USEPA 1983). 
-

○

0 
In general, lakes in the Spanish Peaks Wilderness were more alkaline than lakes previousiy monitored in the East and West Pioneer or in the Beaverhead Mountains (Tables 23-25). Eleven of the twenty lakes that were sampled had total alkalinities of $10 \mathrm{mg} / 1$ or greater whereas only three lakes had total alkalinites less than $5 \mathrm{mg} / 1$. The lowest alkalinity found was $3.5 \mathrm{mg} / 1$ in Jerome Lake No. 1 .

Table 23. Relative sensitivity to acid deposition of 63 alpine lakes from several Montana mountain ranges. Rating scheme developed by EPA and based on total alkalinity of surface waters.

\begin{tabular}{|c|c|c|c|c|c|c|}
\hline \multirow[b]{2}{*}{$\begin{array}{l}\text { Location } \\
\text { of lakes }\end{array}$} & \multirow[b]{2}{*}{$\begin{array}{l}\text { Number } \\
\text { sampled }\end{array}$} & \multicolumn{5}{|c|}{ Sensitivity category (alkalinty range, $\mathrm{mg} / 1$ as $\mathrm{CaCO}_{3}$ ) } \\
\hline & & $\begin{array}{l}\text { Critical } \\
(0-<2)\end{array}$ & $\begin{array}{l}\text { Endangered } \\
(2-<5)\end{array}$ & $\begin{array}{l}\text { Highly } \\
\text { sensitive } \\
(5-<10)\end{array}$ & $\begin{array}{l}\text { Sensitive } \\
(10-<20)\end{array}$ & $\begin{array}{c}\text { Not } \\
\text { sensitive } \\
(\leq 20)\end{array}$ \\
\hline $\begin{array}{l}\text { Beaverhead } \\
\text { Mountains }\end{array}$ & 15 & 1 & 3 & 7 & 4 & 0 \\
\hline $\begin{array}{l}\text { West Pioneer } \\
\text { Mountains }\end{array}$ & 9 & 0 & 5 & 2 & 0 & 2 \\
\hline $\begin{array}{l}\text { East Pioneer } \\
\text { Mountains }\end{array}$ & 18 & 0 & 2 & 8 & 4 & 4 \\
\hline $\begin{array}{l}\text { Spanish } \\
\text { Peaks }\end{array}$ & 20 & 0 & 3 & 6 & 11 & 0 \\
\hline
\end{tabular}

In all of the lakes sampled in the Spanish Peaks, calcium was the predominant cation and bicarbonate the predominant anion (Tables 24-25). This has been true for most of the lakes we have inventoried.

The lowest pH measured was 6.6 in Lower Falls Creek Lake. None of the $\mathrm{pH}$ values that were measured were low enough to represent a hazard to fish populations. 
-

-

○ 
Table 24. Specific conductance, pH, and concentrations of major cations and anions in surface waters from ten alpine lakes in the Spanish Peaks wilderness.

\begin{tabular}{|c|c|c|c|c|c|c|c|c|c|c|c|}
\hline \multirow{2}{*}{$\begin{array}{l}\text { Lake } \\
\text { and } \\
\text { Location }\end{array}$} & \multirow{2}{*}{$\begin{array}{l}\text { Specific } \\
\text { conductance } \\
\text { (umhos } / \mathrm{cm}^{2} \text { ) }\end{array}$} & \multirow[b]{2}{*}{$\mathrm{pH}^{\mathrm{a}}$} & \multicolumn{4}{|c|}{ Major cations $(\mathrm{mg} / 1)$} & \multirow[b]{2}{*}{$\begin{array}{c}\text { Hardness } \\
\left(\mathrm{mg} / 1 \text { as } \mathrm{CaCO}_{3}\right)\end{array}$} & \multicolumn{3}{|c|}{ Major antons $(\mathrm{mg} / \mathrm{l})$} & \multirow{2}{*}{$\begin{array}{c}\text { Total } \\
\text { alkalinity } \\
\left(\mathrm{mg} / 1 \text { as } \mathrm{CaCO}_{3}\right)\end{array}$} \\
\hline & & & $\mathrm{Ca}^{2+}$ & $\mathrm{Mg}^{2+}$ & $\mathrm{Na}^{+}$ & $\mathrm{k}^{+}$ & & $\mathrm{HCO}_{3}$ & $\mathrm{Cl}^{-}$ & $\mathrm{SO}_{4}{ }^{2-}$ & \\
\hline $\begin{array}{l}\text { Hel1 Roaring } \\
\text { (T6S R3E S1) }\end{array}$ & 48 & 6.97 & 6.2 & 0.8 & 0.6 & 1.0 & 19 & 21.2 & $<0.1$ & 3.5 & 17.4 \\
\hline $\begin{array}{l}\text { Beehive } \\
\text { (I5S R2E S31) }\end{array}$ & 36 & 7.10 & 4.1 & 1.0 & 1.0 & 0.9 & 14 & 20.3 & $<0.1$ & 1.2 & 16.6 \\
\hline $\begin{array}{l}\text { Deer } \\
\text { (I6S R4E S7) }\end{array}$ & 23 & 6.98 & 2.2 & 0.3 & 1.1 & 0.6 & 7 & 12.2 & $<0.1$ & 1.2 & 10.0 \\
\hline $\begin{array}{l}\text { Big Brother } \\
\text { (I5S R2E S19) }\end{array}$ & 32 & 7.01 & 4.4 & 0.4 & 0.8 & 0.4 & 13 & 13.2 & $<0.1$ & 1.3 & 10.8 \\
\hline $\begin{array}{l}\text { Moon } \\
\text { (I6S R4E S7) }\end{array}$ & 17 & 6.78 & 1.3 & 0.3 & 0.7 & 0.5 & 4 & 9.1 & $<0.1$ & 1.0 & 7.5 \\
\hline $\begin{array}{l}\text { Lava } \\
\text { (I5S R4E S28) }\end{array}$ & 34 & 7.05 & 3.8 & 0.6 & 1.1 & 1.0 & 12 & 18.3 & 0.1 & 1.3 & 15.0 \\
\hline $\begin{array}{l}\text { Janelle } \\
\text { (T5S R2E S24) }\end{array}$ & 21 & 7.11 & 2.4 & 0.3 & 0.3 & 0.5 & 7 & 10.4 & $<0.1$ & 0.7 & 8.5 \\
\hline $\begin{array}{l}\text { Margo } \\
\text { (T5S R2E S14) }\end{array}$ & 19 & 6.71 & 1.1 & 0.2 & 0.7 & 0.7 & 4 & 6.0 & 1.3 & 0.7 & 4.9 \\
\hline $\begin{array}{l}\text { Little Sister } \\
\text { (T5S R2E S15) }\end{array}$ & 22 & 6.78 & 3.0 & 0.2 & 0.6 & 0.3 & 8 & 13.4 & $<0.1$ & 0.3 & 11.0 \\
\hline $\begin{array}{l}\text { Shea Lake } \\
\text { (T6S R4E S7) }\end{array}$ & 20 & 6.76 & 1.0 & 0.2 & 1.4 & 1.0 & 3 & 8.5 & 1.2 & 0.2 & 7.0 \\
\hline
\end{tabular}

${ }^{\mathrm{a}} \mathrm{pH}$ measurements were made in the laboratory several days after the samples were taken.

CP/war-1b-2 
○

0

0 
Table 25. Specific conductance, pH, and concentrations of major cations and anions in surface waters from ten alpine lakes in the Spanish Peak Wilderness.

\begin{tabular}{|c|c|c|c|c|c|c|c|c|c|c|c|}
\hline \multirow{2}{*}{$\begin{array}{l}\text { Lake } \\
\text { and } \\
\text { Location }\end{array}$} & \multirow{2}{*}{$\begin{array}{l}\text { Speciflc } \\
\text { conductance } \\
\text { (umhos } / \mathrm{cm}^{2} \text { ) }\end{array}$} & \multirow[b]{2}{*}{$\mathrm{pH}^{\mathrm{a}}$} & \multicolumn{4}{|c|}{ Major cations (mg/1) } & \multirow[b]{2}{*}{$\begin{array}{c}\text { Hardness } \\
\left(\mathrm{mg} / 1 \text { os } \mathrm{CaCO}_{3}\right)\end{array}$} & \multicolumn{3}{|c|}{ Major anions (mg/1) } & \multirow{2}{*}{$\begin{array}{c}\text { Tota1 } \\
\text { alkalinity } \\
\left(\mathrm{mg} / 1 \text { os } \mathrm{CaCO}_{3}\right)\end{array}$} \\
\hline & & & $\mathrm{Ca}^{2+}$ & $\mathrm{Mg}^{2+}$ & $\mathrm{Na}^{+}$ & $\mathrm{k}^{+}$ & & $\mathrm{HCO}_{3}$ & $\mathrm{C1}^{-}$ & $\mathrm{SO}_{4}{ }^{2-}$ & \\
\hline $\begin{array}{l}\text { Jumbo No. } 1 \\
\text { (T5S R4E S29 CCA) }\end{array}$ & 27 & 6.75 & 2.8 & 0.3 & 0.8 & 0.8 & 8 & 17.1 & 0.2 & 1.2 & 14.0 \\
\hline $\begin{array}{l}\text { Jumbo No. } 2 \\
\text { (15S R45 S31 DAB) }\end{array}$ & 29 & 7.01 & 3.2 & 0.3 & 0.8 & 0.7 & 9 & 15.2 & $<0.1$ & 0.6 & 12.5 \\
\hline $\begin{array}{l}\text { Jerome Rock No. } 1 \\
\text { (T5S R2E S22 ABC) }\end{array}$ & 15 & 6.79 & 1.1 & 0.1 & 0.5 & 0.3 & 3 & 4.3 & 0.2 & 0.7 & 3.5 \\
\hline $\begin{array}{l}\text { Jerome Rock No. } 2 \\
\text { (TSS R2E S22 BBA) }\end{array}$ & 11 & 6.84 & 1.0 & $<0.1$ & 0.4 & 0.2 & 3 & 4.9 & $<0.1$ & 0.4 & 4.0 \\
\hline $\begin{array}{l}\text { Jerome Rock No. }{ }^{3} \\
\text { (ISS R2E S22 BCA) }\end{array}$ & 11 & 6.77 & 0.9 & $<0.1$ & 0.5 & 0.2 & 3 & 6.1 & $<0.1$ & 0.3 & 5.0 \\
\hline $\begin{array}{l}\text { Spanish No. } 1 \\
\text { (15S R2E S36 ABB) }\end{array}$ & 22 & 6.86 & 2.5 & 0.3 & 0.3 & 0.4 & 7 & 10.4 & $<0.1$ & 1.0 & 8.5 \\
\hline $\begin{array}{l}\text { Spanish No. }{ }^{2} \\
\text { (TSS R2E S36 BAD) }\end{array}$ & 29 & 7.04 & 3.9 & 0.5 & 0.4 & 0.7 & 12 & 14.6 & $<0.1$ & 2.4 & 12.0 \\
\hline $\begin{array}{l}\text { Spanish No. }{ }^{3} \\
\text { (T5S R2E S36 ACC) }\end{array}$ & 31 & 6.95 & 4.0 & 0.5 & 0.4 & 0.8 & 12 & 14.0 & $<0.1$ & 1.9 & 11.5 \\
\hline $\begin{array}{l}\text { Mirror } \\
\text { (I5S R2E S30 ADC) }\end{array}$ & 41 & 6.91 & 5.1 & 0.6 & 0.6 & 0.9 & 15 & 7.8 & $<0.1$ & 1.8 & 6.4 \\
\hline $\begin{array}{l}\text { Lower Falls Creek } \\
\text { (I5S R2E S15 CAA) }\end{array}$ & 24 & 6.60 & 2.7 & 0.2 & 0.9 & 0.4 & 8 & 12.8 & 0.4 & 0.5 & 10.5 \\
\hline
\end{tabular}

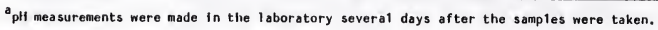

GP/war-1b-1 
o

-

○ 
INVENTORY OF FISHERY HABITAT IN THE UPPER CLARK FORK RIVER

Fish densities in the Clark Fork River decline from nearly $2000 \mathrm{fish} / \mathrm{mile}$ immediately downstream of the Warm Springs Ponds to less than $50 \mathrm{fish} / \mathrm{mile}$ in the Bearmouth reach (Workman 1985). Water quality data indicate that both copper and zinc are sometimes present in the river at concentrations that exceed criteria for protection of aquatic life (see the earlier section of this report describing Clark Fork River bioassays). Phillips (1985) showed that concentrations of metals exceeded criteria for protection of aquatic life for a longer time as you move away from the ponds because the river continues to pick up metals that have been deposited in the river bank. Further, water quality improves downstream from where clean water tributaries enter the Clark Fork including Warm Springs Creek, the Little Blackfoot River and Rock Creek. Higher fish densities below tributaries appear to be correlated with improved water quality.

Some biologists hypothesize that habitat differences may be at least as important as water quality in controlling fish densities in the various reaches of the river. Accordingly, this work was completed to try and gain some understanding of variation in habitat features in different reaches.

\section{Methods}

Seven reaches of the river were inventoried using a modification of the methodology described by Montana Department of Fish, Wildlife and Parks (1983). Reaches inventoried included near Warm Springs, Galen, Deer Lodge, Gold Creek, Drummond, Bearmouth, and Clinton (Fig. 20). Reaches were chosen to roughly 
0

○

- 


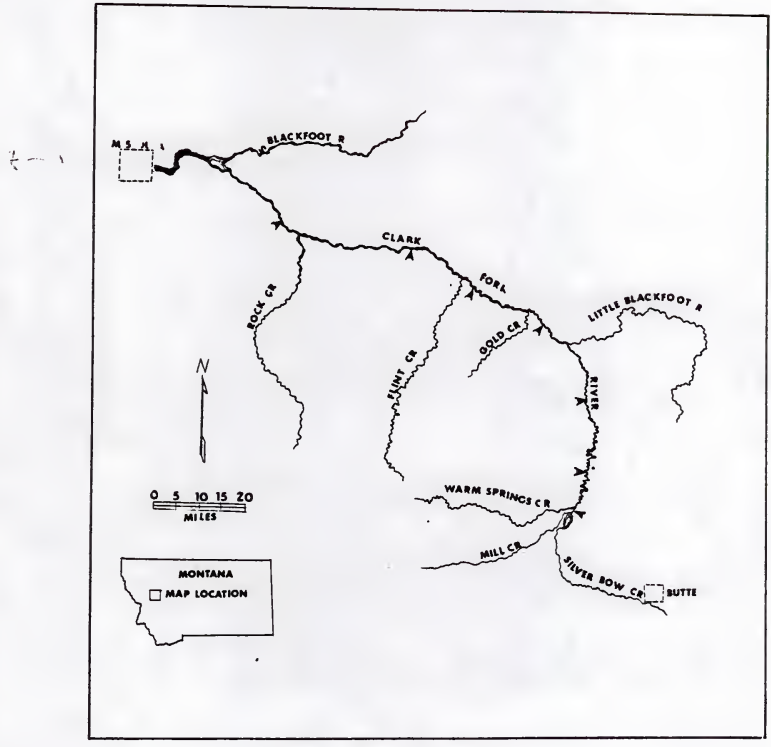

Figure 22. Map of the Clark Fork River; arrows indicate reaches where stream habitat was inventoried. 
.

0

. 
correspond with stream segments where fish populations have been measured. The five upstream reaches that were inventoried were 1,000 feet long and included ten transects that were spaced 100 feet apart within the reach. The two downstream reaches (Bearmouth and $\mathrm{Clinton)}$ were 2,000 feet long and included ten transects were spaced 200 feet apart.

Reach characteristics that were recorded included channel pattern, length of undercut banks (assuming bank-full flow), percentage of reach with overhanging cover, and feet of altered streambank (channelization or riprap). For each reach we also recorded the number of deep runs and pools and the size and maximum depth of each pool.

Characteristics that were measured at each transect included wetted width, total width (from rooted vegetation to rooted vegetation), percent embeddedness of gravel or rubble, and compaction of the bed material. Each transect was also described according to percentage of riffle, run or pool. Depth was measured every three feet along the wetted portion of the transect and the two dominant substrates at each of these points was recorded. This information was used to approximate the average composition of bed material in each transect. Results for all of the transects in a given reach were averaged to arrive at an estimate of bed material composition.

A small boat was used to measure depths at some transects in the Bearmouth area. Swift currents present at two transects in the $\mathrm{Clinton}$ area prevented measurements of depth. 
.

.

0 
The 1985 water year was chosen to perform the inventory because the unusually low river flows facilitated many of the measurements.

\section{Results}

The river has a much more severe meandering pattern in the upper reaches than further downstream (Table 26) and generally becomes wider and deeper in the downstream direction. However, wetted stream width approximately doubled between Galen and Deer Lodge without any significant increase in flow. Consequently, the river is shallower in the Deer Lodge vicinity than upstream -- a result of lower stream gradient in this reach. The above is reflected by the fact that substrates in the Deer Lodge reach are finer than in upstream reaches. Percentages of sand and small detritus in the substrate at each reach were: Deer Lodge - 54\%, Bearmouth - 32\%, Galen - $23 \%$, Gold Creek - $21 \%$, Warm Springs $19 \%$, Drummond - $9 \%$, and Clinton - $0 \%$.

Substrate embeddedness was also greatest at Deer Lodge $175 \%$ ) compared to: Drummond - $40 \%$, Warm Springs - $40 \%$, Bearmouth - 38\%, Galen - 35\%, Gold Creek $25 \%$, and $\mathrm{Cl}$ inton $-25 \%$.

The most favorable substrate conditions were at $\mathrm{Cl}$ inton where virtually the entire substrate consisted of large gravel or larger particles -- a result of Rock Creek waters entering the $\mathrm{Clark}$ Fork. At other locations the percentages of substrate material having large gravel or greater size were: Drummond - $86 \%$, Warm Springs - 70\%, Gold Creek - 56\%, Galen - 53\%, Bearmouth - 45\%, and Deer Lodge - $31 \%$. 
-

-

- 


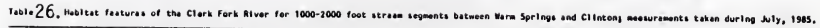

\begin{tabular}{|c|c|c|c|c|c|c|c|c|c|c|c|c|c|c|c|c|c|}
\hline \multirow{2}{*}{$\begin{array}{l}\text { Resch } \\
\text { and } \\
\text { ichennel } \\
\text { ichoe) }\end{array}$} & \multicolumn{3}{|c|}{ Featuras $/ 1000$ it } & \multirow{3}{*}{ 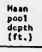 } & \multirow{3}{*}{\multicolumn{2}{|c|}{$\begin{array}{l}\text { Meen Width fft: } \\
\text { votted Iotsf }\end{array}$}} & \multirow{3}{*}{\multicolumn{4}{|c|}{ 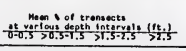 }} & \multirow{3}{*}{$\begin{array}{c}\text { Mesn } \\
\text { cubstr.t. } \\
\text { momboddedness }\end{array}$} & \multirow{2}{*}{\multicolumn{6}{|c|}{ Occurrence of wbitrate types (N). }} \\
\hline & $\begin{array}{l}\text { Pool: } \\
\text { (No.) }\end{array}$ & $\begin{array}{l}\text { Runs, } \\
\text { (Ho.) }\end{array}$ & $\begin{array}{l}\text { lat } \\
\text { bonk } \\
\text { ift.) }\end{array}$ & & & & & & & & & & & & & & \\
\hline & & & & & & & & & & & & detritus & Sand & graval & graval & Cobblo & Bouldar \\
\hline 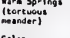 & 6 & 6 & 173 & 3.6 & 33 & $(n=10)^{40}$ & 40 & 41 & $" 1$ & - & 40 & 3 & 16 & $(n=10)$ & 6 & 61 & 3 \\
\hline $\begin{array}{l}\text { Colon } \\
\text { (seani: } \\
\text { tortuous: } \\
\text { meande-i }\end{array}$ & 1 & 6 & 700 & 2.7 & 26 & $(n-10)^{46}$ & 13 & 44 & 34 & 9 & 35 & 3 & ${ }^{20}$ & $(n=80)$ & 3 & so & $\circ$ \\
\hline $\begin{array}{l}\text { Dear Lodge } \\
\text { (requlad } \\
\text { meander) }\end{array}$ & 0 & 2 & $\theta 00$ & - & $\infty$ & $(n=10)^{99}$ & 29 & 46 & 24 & 1 & 75 & 20 & 34 , & $(m=1593)$ & 2 & 29 & 0 \\
\hline $\begin{array}{l}\text { Cold Creek } \\
\text { (1rregular } \\
\text { meander) }\end{array}$ & 1 & . & 600 & 3.0 & 6 & $(n=10)^{129}$ & 26 & 39 & 15 & 2 & 25 & 6 & 15 & $(n-2309)$ & 11 & 40 & 3 \\
\hline $\begin{array}{l}\text { Drumond } \\
\text { (Irreqular } \\
\text { meander) }\end{array}$ & 2 & 3 & 720 & 4.1 & 36 & $(n-10)^{168}$ & 21 & 49 & 14 & 16 & 40 & 2 & 7 & $(n=181)$ & 4 & is & 0 \\
\hline $\begin{array}{l}\text { Eearmouth } \\
\text { (1Hrequilat } \\
\text { neandar) }\end{array}$ & 2 & 7 & 910 & 6.3 & 88 & $(n=10)^{164}$ & 5 & 34 & 33 & 28 & 38 & - & 24 & $(n-3)$ & 6 & 39 & - \\
\hline 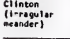 & 1 & 5 & 710 & 5.0 & 110 & $(n=10)^{256}$ & 16 & 23 & 38 & 18 & 25 & 0 & 0 & (n=380) & 49 & 50 & 1 \\
\hline
\end{tabular}

Cp/mar-2b-1 
.

-

0 
Pools were most numerous in the river reach immediately downstream of the Warm Springs Ponds averaging 6 (per $1000 \mathrm{ft}$ ) compared to: Galen - 4, Drummond - 2, Bearmouth - 2, Gold Creek - 1, Clinton - 1, and Deer Lodge - 0. Pools were deeper at Bearmouth and $\mathrm{Clinton}$ than at upstream reaches, having average depths of 6.3 and 5.0 feet respectively.

In conclusion, some habitat features appear to correlate with fish density trends while others do not. Observations include:

(1) Higher percentages of fine materials at Deer Lodge and Bearmouth may limit trout spawning and reduce production of aquatic insects.

(2) Cleaner substrates at Clinton, Drummond, and Warm Springs may favor trout spawning and production of aquatic insects.

(3) Larger numbers of pools in the Warm Springs reach may favor trout.

(4) Habitat differences between Warm Springs and Galen do not account for the decline in fish populations.

(5) The fish population data presently available for the Drummond area do not reflect the apparently favorable substrate conditions.

There are numerous limitations to this data including:

(1) Substrate measurements made during 1985 may not be representative of other years because runoff during 1985 was unusually low. 
-

○

a 
(2) Habitat feature measurements were confined to 1000-2000 foot stream segments. Consequently, the study segments may not necessarily be representative of other segments in a given stream reach. Moreover, fish population estimates and density trends are usually averaged for several miles of stream. Trying to correlate these estimates with habitat features measured over a much shorter reach may be misleading.

(3) Comparisons are further complicated because fish sometimes migrate many miles in order to carry out important life cycle functions such as spawning. Migrations are often into tributaries which have habitat characteristics that differ from the mainstem. Better information on spawning, migration and recruitment from the various segments of the Clark Fork is necessary to be able to interpret habitat characteristics.

(4) Habitat measurements at Warm Springs do not take into account the tailwater influence of the ponds. Biomass of aquatic invertebrates is known to be enriched immediately downstream of the Warm Springs Ponds. This may contribute to the higher densities of brown trout in that reach. 
o

. 


\section{CHLORINATED HYOROCARBONS IN MONTANA FISHES}

In recent years pesticides and other chlorinated hydrocarbons have been found in Montana fishes and game birds (Schladweiler and Weigand 1983; Phillips and Hill 1984). Most chlorinated hydrocarbons are no longer used in Montana or are being phased out of use; however, because of their persistence, many are still present in the environment.

Polychlorinated biphenyls (PCB's) have not been manufactured in the United States since the mid-1970's but PCB's are still commonly used in electrical transformers and capacitors. PCB's have also been used in plasticizers, heat transfer fluids, hydraulic fluids, vacuum pumps, lubricants, compressors, and wax extenders (USEPA 1980). Many of the PCB products that were manufactured years ago continue to leak into the environment today.

The Montana Department of Fish, Wildlife and Parks monitors chlorinated hydrocarbons in the flesh of fishes from several Montana waters each year to determine if fish are safe for sportsmen to eat. Here we report monitoring results from Flathead Lake, the Righorn River near Fort Smith, the Clark Fork River near Plains, and the Missouri River near Carter Ferry.

Methods

Residues tested included DDT and its metabolites DDD and DDE, polychlorinated byphenyls, dieldrin, benzene hexachloride, lindane, hexachlorobenzene, endrin, heptachlor epoxide, mirex, and toxaphene. Chlordane concentration was also determined in Makinaw and bull trout from Flathead Lake. 
。

○

○ 
Fish were collected by electrofishing, gill netting, or angling. As soon as possible after collection, fish were weighed, measured, filleted, and the fillets were wrapped in aluminum foil, placed in plastic bags and frozen. Frozen fish were shipped on dry ice by air freight to Hazelton Raltech Laboratories in Madison, Wisconsin where the residue analyses were performed.

At the laboratory, tissue samples were ground and blended with methyl cyanide. Chlorinated hydrocarbons were partitioned into petroleum ether, dried over anhydrous $\mathrm{Na}_{2} \mathrm{SO}_{4}$, and eluted through a florisil column with $15 \%$ ethyl ether to petroleum ether (volume/volume). Finally, residues were quantified using a gas chromatograph equipped with an electron capture detector (Horiwitz et al. 1975). Results are reported on a wet tissue basis. Detection limits were $0.10 \mathrm{ppm}$ for toxaphene, $0.01 \mathrm{ppm}$ for PCB's and mirex, and 0.005 for all other chlorinated hydrocarbons that were tested.

\section{Results}

Several of the compounds tested were detected in only a few fish and when they were detected they were present at low concentrations (Tables 27-31). None of the fish contained any of the compounds at concentrations exceeding existing guidelines for human consumption.

Bighorn River fish contained detectable levels only of dieldrin and benzene hexachloride and concentrations were barely above the detection limit (Table 27). Fish in the Clark Fork River near Plains contained only PCB's (Table 28); concentrations ranged from $0.11-0.36 \mathrm{ppm}$ (the FDA guideline for human consumption of PCB's is $2.0 \mathrm{ppm}$ ). 
○ 
Jable 27. Concentrations of chlorinated hydrocarbons in muscle tissue from brown trout collected from the Bighorn River near Fort Smith; June and July, 1984.

\begin{tabular}{|c|c|c|c|c|c|c|c|c|c|c|c|c|c|c|}
\hline \multirow[b]{2}{*}{ Species } & \multirow{2}{*}{$\begin{array}{l}\text { Length } \\
(\mathrm{cm})\end{array}$} & \multirow{2}{*}{$\begin{array}{c}\text { Weight } \\
(g)\end{array}$} & \multicolumn{11}{|c|}{ Residue concentration $(\mathrm{ppm})^{e}$} & \multirow[b]{2}{*}{ Toxaphene } \\
\hline & & & DDE & DDD & DDT & $P C B^{\circ}$ & Dieldrin & $\mathrm{BHC}^{\mathrm{b}}$ & Lindane & $\operatorname{IICB}{ }^{c}$ & Endrin & $H E^{d}$ & Mirex & \\
\hline \multirow[t]{13}{*}{ Brown trout } & 44 & 1044 & nd & nd & nd & nd & nd & nd & nd & nd & nd & nd & nd & nd \\
\hline & 43 & 781 & nd & nd & nd & nd & nd & 0.006 & nd & nd & nd & nd & nd & nd \\
\hline & 45 & 835 & nd & nd & nd & nd & nd & nd & nd & nd & nd & nd & nd & nd \\
\hline & 51 & 999 & nd & nd & nd & nd & nd & nd & nd & nd & nd & nd & nd & nd \\
\hline & 41 & 917 & nd & nd & nd & nd & 0.005 & nd & nd & nd & nd & nd & nd & nd \\
\hline & 40 & 817 & nd & nd & nd & nd & 0.020 & 0.009 & nd & nd & nd & nd & nd & nd \\
\hline & 47 & 1094 & nd & nd & nd & nd & nd & nd & nd & nd & nd & nd & nd & nd \\
\hline & 49 & 972 & nd & nd & nd & nd & nd & nd & nd & nd & nd & nd & nd & nd \\
\hline & 34 & 1008 & nd & nd & nd & nd & 0.005 & 0.008 & nd & nd & nd & nd & nd & nd \\
\hline & 36 & 604 & nd & nd & nd & nd & nd & 0.007 & nd & nd & nd & nd & nd & nd \\
\hline & 28 & 291 & nd & nd & nd & nd & nd & nd & nd & nd & nd & nd & nd & nd \\
\hline & 30 & 300 & nd & nd & nd & nd & nd & nd & nd & nd & nd & nd & nd & nd \\
\hline & 20 & 104 & nd & nd & nd & nd & nd & nd & nd & nd & nd & nd & nd & nd \\
\hline
\end{tabular}

aPCB denotes polychlorinated biphenyls.

$\mathrm{b}_{B \mathrm{BIC}}$ denotes benzene hexachloride.

cHCB denotes hexachlorobenzene.

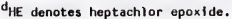

end indicates none detected; detection limits were $0.10 \mathrm{ppm}$ for toxaphene,

$0.01 \mathrm{ppm}$ for mirex, and $0.005 \mathrm{ppm}$ for all other chlorinated hydrocarbons. 
O

O

○ 
Table 28. Concentrations of chlorinated hydrocarbons in muscle tissue from mountain whitefish collected from the Clark Fork River near Plains during October 1985.

\begin{tabular}{|c|c|c|c|c|c|c|c|c|c|c|c|c|c|c|}
\hline \multirow[b]{2}{*}{ Species } & \multirow[b]{2}{*}{$\begin{array}{l}\text { Length } \\
(\mathrm{cm})\end{array}$} & \multirow[b]{2}{*}{$\begin{array}{l}\text { Weight } \\
\text { (g) }\end{array}$} & \multicolumn{11}{|c|}{ Residue concentration $(\mathrm{ppm})^{\mathrm{e}}$} & \multirow[b]{2}{*}{ Toxaphene } \\
\hline & & & DDE & $\mathrm{DDD}$ & DDT & $\mathrm{PCB}^{\mathrm{a}}$ & Dieldrin & $\mathrm{BHC}^{\mathrm{b}}$ & Lindane & $\mathrm{HCB}^{\mathrm{C}}$ & Endrin & $H E^{d}$ & Mirex & \\
\hline \multirow[t]{8}{*}{$\begin{array}{l}\text { Mountain } \\
\text { whitefish }\end{array}$} & 35 & 420 & nd & nd & nd & 0.21 & nd & nd & nd & nd & nd & nd & nd & nd \\
\hline & 36 & 440 & nd & nd & nd & 0.36 & nd & nd & nd & nd & nd & nd & nd & nd \\
\hline & 33 & 350 & nd & nd & nd & 0.27 & nd & nd & nd & nd & nd & nd & nd & nd \\
\hline & 33 & 340 & nd & nd & nd & nd & nd & nd & nd & nd & nd & nd & nd & nd \\
\hline & 28 & 250 & nd & nd & nd & 0.11 & nd & nd & nd & nd & nd & nd & nd & nd \\
\hline & 26 & 190 & nd & nd & nd & nd & nd & nd & nd & nd & nd & nd & nd & nd \\
\hline & 26 & 170 & nd & nd & nd & nd & nd & nd & nd & nd & nd & nd & nd & nd \\
\hline & 35 & 515 & nd & nd & nd & 0.16 & nd & nd & nd & nd & nd & nd & nd & nd \\
\hline
\end{tabular}

aPCB denotes polychlorinated biphenyls.

bBHC denotes benzene hexachloride.

$c_{\text {HCB denotes hexachlorobenzene. }}$

${ }_{\text {HE denotes heptachlor epoxide. }}$

end indicates none detected; detection limits were $0.10 \mathrm{ppm}$ for PCB and toxaphene,

$0.01 \mathrm{ppm}$ for mirex, and $0.005 \mathrm{ppm}$ for all other chlorinated hydrocarbons. 
-

-

○ 
Table 29. Concentrations of chlorinated hydrocarbons in muscle tissue from brown trout, rainbow trout, and mountain whitefish collected from the Missouri River near Carter ferry during June 1986.

\begin{tabular}{|c|c|c|c|c|c|c|c|c|c|c|c|c|c|}
\hline \multirow[b]{2}{*}{ Species } & \multirow[b]{2}{*}{$\begin{array}{l}\text { Length } \\
\text { (cn) }\end{array}$} & \multirow[b]{2}{*}{$\begin{array}{l}\text { Weight } \\
\text { (g) }\end{array}$} & \multicolumn{10}{|c|}{ Residue concentration $(\mathrm{ppm})^{\circ}$} & \multirow[b]{2}{*}{ Toxaphene } \\
\hline & & & DDE & DDD & DDT & $\mathrm{PCB}^{\mathrm{a}}$ & Dieldrin & BHC $^{b}$ & $\mathrm{HCB}^{\mathrm{c}}$ & Endrin & $\mathrm{HE}^{\mathrm{d}}$ & Mirex & \\
\hline \multirow[t]{4}{*}{$\begin{array}{l}\text { Brown } \\
\text { trout }\end{array}$} & 51 & 1090 & 0.06 & nd & 0.06 & 0.28 & nd & 0.01 & nd & nd & nd & nd & nd \\
\hline & 41 & 608 & 0.01 & nd & 0.01 & 0.07 & nd & 0.01 & nd & nd & nd & nd & nd \\
\hline & 37 & 400 & nd & nd & nd & 0.02 & nd & nd & nd & nd & nd & nd & nd \\
\hline & 29 & 232 & nd & nd & nd & nd & nd & nd & nd & nd & nd & nd & nd \\
\hline $\begin{array}{l}\text { Rainbow } \\
\text { trout }\end{array}$ & 38 & 440 & nd & nd & nd & nd & nd & nd & nd & nd & nd & nd & nd \\
\hline \multirow[t]{8}{*}{$\begin{array}{l}\text { Mountain } \\
\text { whitefish }\end{array}$} & 44 & 981 & 0.01 & nd & 0.01 & 0.05 & nd & nd & nd & nd & nd & nd & nd \\
\hline & 49 & 1230 & 0.03 & nd & 0.04 & 0.21 & 0.01 & 0.01 & nd & nd & nd & nd & nd \\
\hline & 49 & 1081 & 0.01 & nd & 0.02 & 0.12 & 0.01 & nd & nd & nd & nd & nd & nd \\
\hline & 44 & 779 & 0.09 & 0.01 & 0.10 & 0.41 & nd & nd & nd & nd & nd & nd & nd \\
\hline & 47 & 1149 & 0.10 & 0.01 & 0.12 & 0.49 & nd & 0.01 & 0.01 & nd & nd & nd & nd \\
\hline & 49 & 1249 & 0.09 & 0.01 & 0.10 & 0.46 & nd & 0.01 & 0.01 & nd & nd & nd & nd \\
\hline & 49 & 1049 & 0.03 & nd & 0.04 & 0.22 & nd & 0.01 & nd & nd & nd & nd & nd \\
\hline & 22 & 109 & 0.01 & nd & 0.01 & 0.05 & nd & nd & nd & nd & nd & nd & nd \\
\hline
\end{tabular}

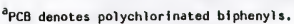

bBC denotes benzene hexachloride.

$c_{\text {HCB denotes hexachlorobenzene. }}$

$d_{\text {HE denotes heptachlor epoxide. }}$

end indicates none detected; detection limits were 0.10 ppm for PCB and toxaphene,

$0.01 \mathrm{ppm}$ for mirex, and $0.005 \mathrm{ppm}$ for all other chlorinated hydrocarbons. 
0

-

0 
Table 30. Concentrations of chlorinated hydrocarbons in muscle tissue from kokanee salmon collected from Flathead Lake at Skidoo Bay; May 12 , 1984.

\begin{tabular}{|c|c|c|c|c|c|c|c|c|c|c|c|c|c|c|}
\hline \multirow[b]{2}{*}{ Species } & \multirow[b]{2}{*}{$\begin{array}{l}\text { Tissue } \\
\text { sampled }\end{array}$} & \multicolumn{13}{|c|}{ Residue concentration $(\mathrm{ppm})^{f}$} \\
\hline & & DOE & ODO & ODT & $P C B^{a}$ & Oieldrin & Alpha-BHC & Beta-BHC $C^{C}$ & Lindane & $\mathrm{HCB}^{\mathrm{d}}$ & Endrin & $\mathrm{HE}^{\mathrm{e}}$ & Mirex & Toxaphene \\
\hline \multirow[t]{9}{*}{$\begin{array}{l}\text { Kokanee } \\
\text { salmon }\end{array}$} & Muscle & 0.032 & 0.013 & 0.030 & 0.33 & 0.021 & 0.041 & 0.009 & nd & nd & 0.005 & 0.005 & nd & nd \\
\hline & Muscle & 0.047 & 0.020 & 0.062 & 0.57 & 0.029 & 0.057 & 0.014 & nd & nd & 0.009 & 0.005 & nd & nd \\
\hline & Muscle & 0.035 & 0.014 & 0.033 & 0.34 & 0.023 & 0.048 & 0.010 & nd & nd & 0.009 & 0.006 & nd & nd \\
\hline & Muscle & 0.033 & 0.013 & 0.025 & 0.30 & 0.021 & 0.041 & 0.010 & nd & nd & 0.006 & 0.006 & nd & nd \\
\hline & Muscle & 0,047 & 0.016 & 0.050 & 0.52 & 0.029 & 0.057 & 0.010 & nd & nd & 0.008 & 0.008 & nd & nd \\
\hline & Muscle & 0.044 & 0.017 & 0.060 & 0.57 & 0.030 & 0.058 & 0.012 & nd & nd & 0.007 & 0.008 & nd & nd \\
\hline & Muscle & nd & nd & nd & nd & nd & 0.017 & nd & nd & nd & nd & nd & nd & nd \\
\hline & Liver & 0.022 & nd & nd & nd & nd & 0.021 & nd & nd & nd & nd & nd & nd & nd \\
\hline & $\begin{array}{c}\text { Viscral } \\
\text { Fat }\end{array}$ & 0.045 & 0.017 & 0.030 & 0.34 & 0.034 & nd & nd & nd & nd & nd & 0.010 & nd & nd \\
\hline
\end{tabular}

${ }^{a} \mathrm{PCB}$ denotes polychlorinated biphenyls.

bAlpha-BHC denotes alpha-benzene hexachloride.

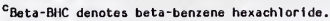

dHCB denotes hexachl robenzene.

eHE denotes heptachlor epoxide.

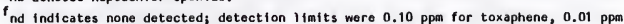

for PCB and mirex, and $0.005 \mathrm{ppm}$ for all other chiorinated hydrocarbuns. 
0

-

○ 

Table 31. Concentrations of chlorinated hydrocarbons in muscie tissue from lake trout and buill trout collected from the west side of flathead Lake
during February or Aprii of 1985 .

\begin{tabular}{|c|c|c|c|c|c|c|c|c|c|c|c|c|c|c|}
\hline \multirow[b]{2}{*}{ Species } & \multirow{2}{*}{$\begin{array}{l}\text { Length } \\
(\mathrm{cm})\end{array}$} & \multirow{2}{*}{$\begin{array}{c}\text { Weight } \\
\text { (g) }\end{array}$} & \multicolumn{12}{|c|}{ Residue concentration $(\mathrm{ppm})^{0}$} \\
\hline & & & DDE & DOD & DDT & $\mathrm{PCB}^{\circ}$ & Dieidrin & $B H C^{b}$ & $\mathrm{HCB}^{\mathrm{C}}$ & Endrin & $\mathrm{HE}^{\mathrm{d}}$ & Mirex & Toxaphene & Chiordane \\
\hline \multirow[t]{7}{*}{ Lake trout } & 94 & -- & 0.22 & 0.09 & 0.15 & nd & 0.03 & nd & nd & nd & nd & nd & 1.30 & 0.06 \\
\hline & 63 & $\cdots$ & 0.05 & 0.01 & 0.02 & 0.05 & 0.01 & nd & nd & nd & nd & nd & 0.16 & 0.01 \\
\hline & 66 & - & 0.06 & 0.02 & 0.02 & 0.05 & 0.01 & nd & nd & nd & nd & nd & 0.20 & 0.01 \\
\hline & 92 & 6.8 & 0.80 & 0.09 & 0.26 & 0.21 & nd & nd & nd & nd & nd & nd & 0.88 & 0.04 \\
\hline & 89 & 7.7 & 0.43 & 0.11 & 0.29 & 0.28 & 0.04 & nd & nd & nd & nd & nd & 1.70 & 0.07 \\
\hline & 91 & 7.7 & 0.08 & 0.05 & 0.07 & 0.06 & 0.02 & nd & nd & 0.01 & nd & nd & 0.48 & 0.04 \\
\hline & 89 & 7.3 & 0.12 & 0.03 & 0.09 & nd & 0.03 & nd & 0.01 & nd & nd & nd & 0.75 & 0.04 \\
\hline \multirow[t]{3}{*}{ Bull trout } & 72 & 5.4 & 0.09 & 0.02 & 0.02 & 0.09 & 0.01 & nd & nd & nd & nd & nd & 0.29 & 0.02 \\
\hline & 65 & 4.0 & 0.04 & 0.01 & 0.02 & nd & 0.01 & nd & nd & nd & nd & nd & 0.11 & 0.01 \\
\hline & 72 & 4.5 & 0.04 & 0.01 & 0.01 & 0.05 & nd & nd & nd & nd & nd & nd & 0.05 & 0.10 \\
\hline
\end{tabular}

APCB denotes polychiorinated biphenyis.

bBHC denotes benzene hexachloride.

cHCB denotes hexachlorobenzene.

dHE denotes heptachior epoxide. end Indicates none datected $;$ detection I Imits were $0.05 \mathrm{ppm}$ for PCB and toxaphene, 0.01 for mirex,
$0.005 \mathrm{ppm}$ for all other chiorinated hydrocarbons. 
O

○

0 
Fish from the Missouri River near Carter ferry contained trace amounts of DDT, DDD, DDE, benzene hexachloride and hexachlorobenzene (Table 29). Concentrations of PCB's ranged from $0.02-0.49 \mathrm{ppm}$.

A greater variety of pesticides were present in Flathead Lake fish than from other locations tested (Tables 30-31). Compounds that were found included: $D D E, D D D, D D T, P C B$, dieldrin, benzene hexachloride, hexachlorobenzene, endrin, heptachlor epoxide, toxaphene, and chlordane. Most were present at concentrations lower than $0.1 \mathrm{ppm}$ al though a few compounds were found at higher concentrations including: $0.8 \mathrm{ppm}-\mathrm{DDE}, 0.11 \mathrm{ppm}-\mathrm{DDD}, 0.29 \mathrm{ppm}-\mathrm{DDT}, 0.57 \mathrm{ppm}-$ $\mathrm{PCB}$, and $1.7 \mathrm{ppm}$ - toxaphene.

The FDA action levels for fish are: $5.0 \mathrm{ppm}$ (DDT, DDD, DDT, Toxaphene); and 2.0 $\mathrm{ppm}$ ( $\left.P C B^{\prime} s\right)$. Thus, even the highest concentrations found were approximately one-third or less of the recommended guideline. Restrictive warnings on consumption of fish do not appear to be necessary. 
0

-

○ 


\section{SUPERSATURATION OF DISSOLVED GASES IN THE}

MISSOURI RIVER DOWNSTREAM OF HAUSER DAM

Plunging of water below dams causes air (composed primarily of nitrogen and oxygen) to become entrained, sometimes resulting in supersaturated conditions. When the level of supersaturation reaches $110 \%$ or more fish may develop signs of gas bubble trauma. Symptoms include bubbles in the tissues including under the surface of the skin (emphysema) and formation of emboli in blood vessels.

Severely affected fish may suffer protrusions of the eyeballs (exophthalmia). symptoms occur when the pressure of gases present in the blood and tissues of the fish are greater than the compensating pressures provided by the atmosphere and overlying water.

Fish may compensate for supersaturation by moving to areas of greater water depth; however, fish commonly seek shallow areas to carry out essential livecycle activities such as spawning.

In May of 1985 the Department was notified that sportsmen were catching fish below Hauser Dam that were suffering symptoms of gas bubble trauma. According$1 y$, we monitored gas saturation levels below the dam from May 6 to May 20. Montana Power Company willingly varied their spillage patterns during the test to allow us to evaluate the effect of various operational patterns on gas supersaturation in the river.

Methods

Percent saturation of total dissolved gases was measured in the Missouri River below Hauser Dam on May $6,10,16,17$, and 20. Measurements were made using a 
-

-

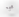

○ 
Weiss saturometer, barometric pressure was obtained from the weather station at the Helena airport, water temperature was determined with a mercury thermometer, and dissolved oxygen was measured using powdered reagents and the azide modification of the standard Winkler method (APHA 1976).

Results

Saturation of total dissolved gas reached $112 \%$ below the dam on May 10, 1985 and then decreased to $106.5 \%$ by May 17 (Table 32). Dissolved oxygen concentrations did not exceed $100 \%$ of saturation, consequently total gas supersaturation must have been primarily due to nitrogen. Total dissolved gases were somewhat supersaturated in both Canyon Ferry Lake and Hauser Lake (to about 105\%) perhaps due to warming of the water in the spring. Water passing through the power houses of both Canyon Ferry and Hauser Dams was slightly more saturated than reservoir water, averaging about $107 \%$.

On the date that saturation of total gases was measured below the power house (107.7\%) at Hauser Dam we also measured $108.9 \%$ in the stilling basin below the spillways. Spillage therefore also appears to cause an additional increase in supersaturation of gases.

On May 16 spillage patterns were varied from the dam by adjusting the various outfall bays to test whether supersaturation below the dam could be controlled by adjusting spillage. However, spillage pattern did not affect the level of supersaturation measured. 
0

(

- 
Table 32. Dissolved oxygen concentration, water temperature, and percent saturation of total dissolved gases in the Missouri River downstream of Hauser Dam under various dam spillage patterns in May, 1985.

\begin{tabular}{|c|c|c|c|c|c|c|}
\hline Date & $\begin{array}{l}\text { Time of } \\
\text { day }\end{array}$ & Location $^{a}$ & $\underset{\text { (pattern) }}{\text { Spillage }}$ & $\begin{array}{c}\text { Dissolved } \\
0_{2} \\
\mathrm{mg}^{2} / 1\end{array}$ & $\begin{array}{l}\text { Water } \\
\text { temp. } \\
\left({ }^{\circ} \mathrm{C}\right)\end{array}$ & $\begin{array}{l}\text { Saturation of } \\
\text { total dissolved } \\
\text { gases } \\
(\%)\end{array}$ \\
\hline May 6 & 1610 & Below Hauser Dam & bay 14 only & -- & 7.0 & 111.4 \\
\hline May 10 & 1430 & Below Canyon Ferry & no spillage & -- & 6.1 & 107.3 \\
\hline May 10 & 1600 & Below Hauser Dam & bay 14 only & -- & 6.9 & 112.0 \\
\hline May 16 & 0900 & Below Hauser Dam & bays 10 and 14 & 12.3 & 7.2 & 108.9 \\
\hline May 16 & 1100 & Power house & -- & 11.4 & 7.8 & 107.7 \\
\hline May 16 & 1230 & Below Hauser Dam & bays 3 and 8 & 11.4 & 7.9 & 108.0 \\
\hline May 16 & 1345 & Below Hauser Dam & bay 14 only & 11.3 & 7.9 & 108.2 \\
\hline May 16 & 1445 & Below Hauser Dam & bay 10 only & 11.4 & 8.2 & 108.5 \\
\hline May 16 & 1610 & Below Hauser Dam & bay 14 only & 11.9 & 8.0 & 107.8 \\
\hline May 17 & 1100 & Below Hauser Dam & bay 14 only & 11.7 & 7.9 & 106.5 \\
\hline May 20 & 1500 & Hauser Lake & -- & -- & 14.0 & 105.0 \\
\hline May 20 & 1600 & Canyon Ferry Lake & -- & -- & 14.0 & 105.3 \\
\hline
\end{tabular}

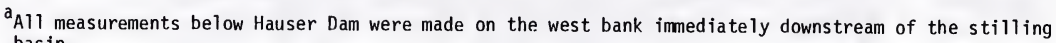
basin.

$b_{\text {Between }} 1500$ and 1600 hours each day, spillage was reduced from approximately $950 \mathrm{cfs}$ to $475 \mathrm{cfs}$. At approximately 0800 hours each day spillage was increased from $475 \mathrm{cfs}$ to $950 \mathrm{cfs}$. Approximately 4,300 cfs was passing through the power house. 
0

○

- 
Symptoms of gas bubble trauma observed in fishes on May 5 had apparently disappeared by May 20. Biologists electrofishing the river on May 20 were unable to capture fish exhibiting symptoms of the disease. Over that period total gas saturation in the river had declined from $112 \%$ to $105 \%$.

Early May, the time when fish with symptoms of gas bubble trauma were observed in the river, is the spawning season for rainbow trout. Trout typically move into shallow water during spawning which would tend to increase their susceptibility to gas bubble trauma. The fact that symptoms of gas bubble trauma have not been observed in previous years leads us to conclude that the problem is not serious and probably occurs only rarely.

GP/war-7b 
0

○

o 


\section{REFERENCES}

Alderdice, D.F., W.P. Wickett, and J.R. Brett. 1958. Some effects of temporary exposure to low dissolved oxygen levels on pacific salmon eggs. J. Fish. Res. Board Can. 15:229-249.

American Public Health Assocaition. 1976. Standard methods for the examination of water and wastewater, 14th edition. American Public Health Association, Washington, D.C., USA.

Chapman, G.A. 1978. Toxicities of cadmium, copper, and zinc to four juvenile stages of chinook salmon and steelhead. Trans. Am. Fish. Soc. 107:841847.

Davis, G.E., J. Foster, C.E. Warren, and P. Doudoroff. 1963. The influence of oxygen concentration on the swimming performance of juvenile Pacific salmon at various temperatures. Trans. Am. Fish. Soc. 92:111-124.

Davis, J.C. 1975. Minimal dissolved oxygen requirements of aquatic life with emphas is on Canadian species. J. Fish. Res. Board Can. 32:2295-2332.

Garton, R.B. 1972. Biological effects of cooling tower blowdown. Amer. Inst. of Chem. Eng. Symp. Ser. 69:284-292.

Holeton, G.F. 1970. Respiratory and circulatory responses of rainbow trout larvae to carbon monoxide and to hypoxia. J. Exp. Biol. 55:683-694.

Horiwitz, W., A. Sengel, and H. Reynolds (eds.). 1975. Official methods of analysis of the Association of Official Analytical Chemists. AOAC, Washington, D.C. 1094 p.

Jeffries, D.S., C.M. Cox, and P.J. Dillon. 1979. Depression of $\mathrm{pH}$ in lakes and streams in central Ontario during snowmelt. J. Fish. Res. Board. Can. $36: 640-646$.

Menendez, R. 1976. Chronic effects of reduced pH on brook trout (Salvelinus fontinalis). J. Fish. Res. Board Can. 33(1):118-123.

Miller, T.G. and W.C. Mackay. 1980. The effects of hardness, alkalinity and pH of test water on the toxicity of copper to rainbow trout (Salmo gairdneri). Water Res. 24:129-133.

Montana Department of Fish, Wildlife and Parks. 1983. Stream habitat inventory procedures. Research and Special Projects Bureau, Helena, MT. 42 p.

Phillips, G.R. 1985. Relationships among fish populations, metals concentrations, and stream discharge in the upper Clark Fork River. Pages 57-73. In: Proceedings Clark Fork River Symbosium, Mont. Acad. Sci., Mont. College Mineral Sci. and Tech. Butte, MT. 
-

○

. 
Phillips, G.R. and K. Hill. 1986. Evaluation of sources and toxicity of copper and zinc in the Boulder River drainage, Jefferson County - 1985. Pollut. Control Info. Ser., Tech. Rep. No. 4, Mont. Dept. Fish, Wildl. and Parks, Helena. 28 pp.

Phillips, G.R., and K. Hill. 1984. Statewide water pollution studies, biennial report 1982-83. Pollut. Control Info. Ser., Tech. Rep. No. 2, Mont. Dept. Fish, Wildl. and Parks, Helena. $65 \mathrm{p}$.

Parrish, L., and G. Rodriguez. 1986. A thirty day flow through bioassay test on copper and zinc toxicity in the Clark Fork River near Deer Lodge. EPA 908/3-86-001. U.S. Environmental Protection Agency, Denver, C0. 54 p.

Schladweiler, P., and J.P. Weigand. 1983. Relationships of endrin and other chlorinated hydrocarbon compounds to wildlife in Montana, 1981-82. Wildl. Div., Mont. Dept. Fish, Wildl. and Parks, Helena. 230 p.

Soil Conservation Service. 1981. Montana snowfall pH study, winter 1980-81. Snow survey and water supply forecast unit, Bozeman, MT. $18 \mathrm{pp}$.

Soil Conservation Service. 1982. Montana snowfall pH study, winter 1981-82. Snow survey and water supply forecast unit, Bozeman, MT.

Soil Conservation Service. 1983. Montana snowfall pH study, winter 1982-83. Snow survey and water supply forecast unit, Bozeman, MT.

U.S. Department of Health, Education and Welfare. 1981. Action levels for poisonous or deleterious substances in human food and anumal feed. USDHEW/PHS/FDA, Wash. D.C. 13 p.

U.S. Environmental Protection Agency. 1983. Methods for chemical analysis of water and wastes. EPA-600/4-79-020. Environ. Monitor. Support Lab., USEPA, Cincinnati, Ohio.

U.S. Environmental Protection Agency. 1985a. Ambient aquatic life water quality criteria for copper. USEPA, Duluth, Minnesota. $141 \mathrm{p}$.

U.S. Environmental Protection Agency. 1985b. Ambient aquatic life water quality criteria for zinc. USEPA, Duluth, Minnesota. $141 \mathrm{p}$.

U.S. Environmental Protection Agency. 1980. Ambient water quality criteria for polychlorinated biphenyls. EPA 440/5-80-068. Criteria and Standards Div., Wash. D.C. $117 \mathrm{p}$.

Workman, D.W. 1985. Trout populations in the Clark Fork River, Warm Springs to Superior, Montana. Pages 156-161. In: Proceedings Clark Fork River Symposium, Mont. Acad. Sci., Mont. CoTlege Mineral Sci. and Tech., Butte, MT.

GP/war-7b 
0

.

. 